\title{
A paleolimnological investigation of agricultural intensification, water quality and ecosystem change at Lake Nganoke, southern Wairarapa, NZ
}

By

Jakob Ethan Parrish

A thesis submitted to Victoria University of Wellington in partial fulfilment of the requirements for the degree of Master of Science 2020 


\section{ABSTRACT}

Decreasing water quality of lakes as a result of anthropogenic landuse and specifically agricultural intensification is well documented in New Zealand. However, monitoring records of lake health are typically short, only commencing once signs of lake deterioration are observed. The shortness of the instrumental record precludes a detailed understanding of the relationship between landuse change, lake ecosystem trajectories and the effectiveness of mitigation strategies such as riparian planting. Paleolimnological reconstruction from sediment cores has the potential to develop high-resolution time series that may extend lake monitoring centuries into the past. This thesis uses paleoenvironmental reconstruction to investigate lake ecosystem change and water quality in Lake Nganoke, Wairarapa, New Zealand as a result of landuse intensification. The primary aim of this thesis is to reconstruct the past environment of Lake Nganoke from a pre-human reference state to the current day to assess: 1) how increased nutrient fluxes associated with landuse intensification have impacted the lake ecosystem; and 2) the ability of riparian zones to buffer these fluxes. The reconstruction was achieved using a multi proxy approach with pre and post-human environments of Lake Nganoke characterised using Palynology, geochemistry, eDNA and hyperspectral scanning.

Māori land clearance was identified at AD 1450 (95\% CI: AD 1417-1551). The appearance of Pinus pollen and increases in fertilisation and stocking rates placed European arrival at AD 1850 (95\% CI: 1809 - 1870), while intensification of agricultural landuse occurred post AD 1950 (95\% CI: 1948 - 1964). The prehuman environment of Lake Nganoke experienced little change, with the catchment dominated by tall trees and likely heavily forested. The lake ecosystem and water quality during this time showed little to no change, with algal productivity likely driven by a constant input of natural nutrients. Post Māori arrival, algal productivity was reduced suggesting an increase in water quality likely driven by added lake marginal plants providing a riparian buffer to terrestrially derived nutrients. Lake productivity increased dramatically post European arrival $\sim \mathrm{AD} 1850$, coeval with an increase in sediment $\mathrm{Cd}$, suggesting that fertilisation may have driven a decline in water quality. Further increases in fertilisation and stocking rates indicate additional agricultural nutrient fluxes entering Lake Nganoke in AD 1950 when agriculture intensified. Abundances in denitrifying Gammaproteobacteria indicate increases in nutrient loading while bloom forming Cyanobacteria peak AD 2000 before declining till present. Riparian planting following Māori arrival appears sufficient to buffer the lake against increased terrestrial nutrient fluxes associated with land clearing. 
However, a riparian zone that covers the majority of the catchment post European settlement was inadequate in altering the lake's degrading ecosystem and water quality trajectory. 


\section{ACKNOWLEDGMENTS}

First and foremost, I would like to thank my supervisors, Jamie Howarth and Andrew Rees. Jamie, thank you for your guidance, extensive knowledge and high standards that have enabled me to elevate my work. Andrew, thank you for your support, patience and being the good cop to Jamie's bad cop. You both have been amazing to work with and have helped shape myself and this thesis into the quality it has become. Secondly, I would like to acknowledge Marcus, Susie and the Lakes 380 team who have supported this thesis. Georgia, Mailys and the wider Cawthron group, who helped carry out the DNA analysis and John, who put up with my multiple questions about ' $r$ ' coding. Claire, Lizette and the staff at GNS, who's work ethic and lab skills are second to none and helped with the initial sampling and hyperspectral scanning of Lake Nganoke cores. Thank you, Xun Li who carried out the pollen analysis and Sean Waters who first pioneered the idea of phosphorous fractionation downcore. A massive appreciation must go towards the office crew, Laura, Pip, Steph, Maia and Megan who put up with my insistent questions and lack of foundation in geology. Lastly, I would like to thank my family and Tyler for their support and encouragement. Thank you - for this would not have been possible without you. 


\section{TABLE OF CONTENTS}

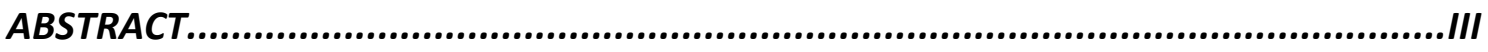

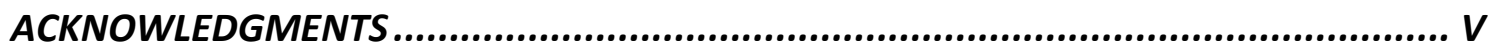

TABLE OF CONTENTS.................................................................................. VII

LISTS OF FIGURES.............................................................................

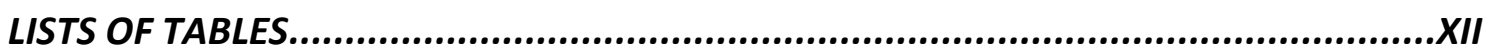

LISTS OF EQUATIONS .........................................................................

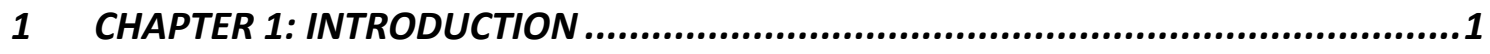

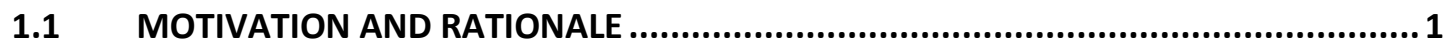

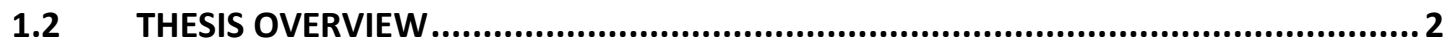

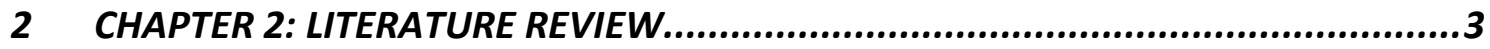

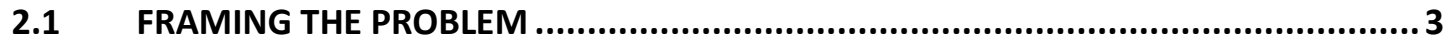

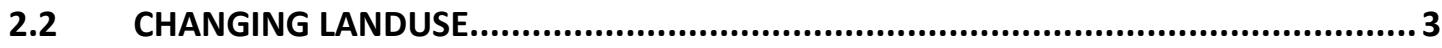

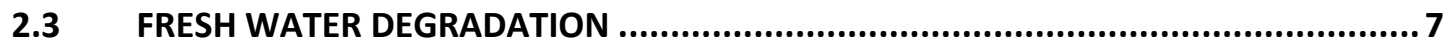

2.4 AGRICULTURAL POLLUTANT MITIGATION: RIPARIAN PLANTING .........................9

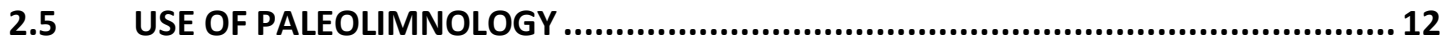

2.5.1 DRIVERS OF LAKE ECOSYSTEM AND WATER QUALITY CHANGE ..................................... 13

2.5.2 MEASURES OF LAKE WATER QUALITY AND ECOSYSTEM CHANGE...................................... 14

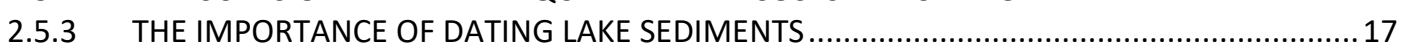

3 CHAPTER 3: RESEARCH HYPOTHESES AND OBJECTIVES ................................19

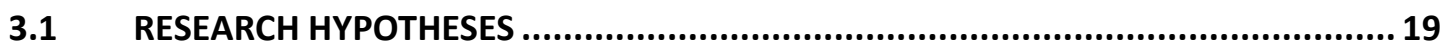

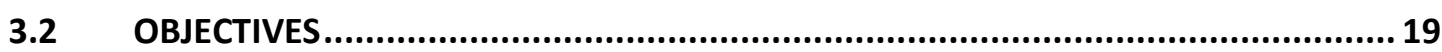

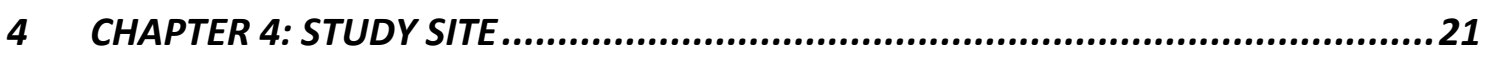

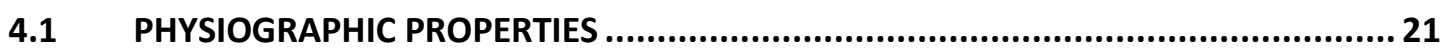

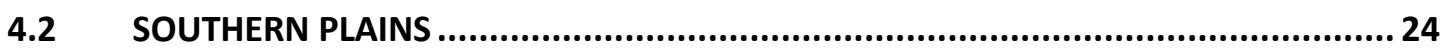

4.3 HUMAN SETTLEMENT AND AGRICULTURAL DEVELOPMENT ................................. 25

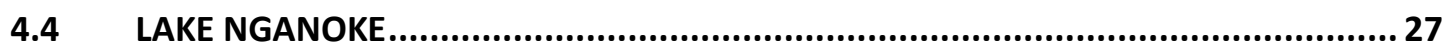

5 CHAPTER 5: METHODOLOGY AND METHODS ............................................29

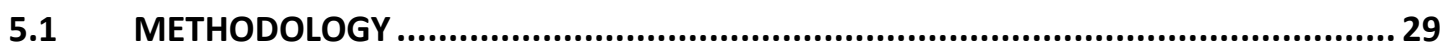

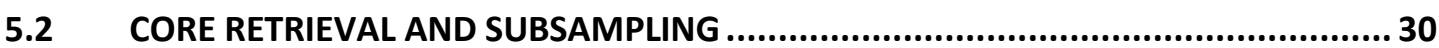

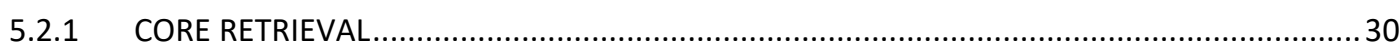

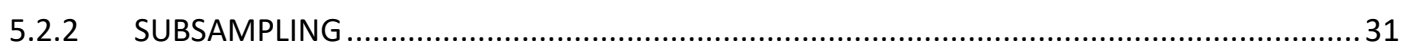

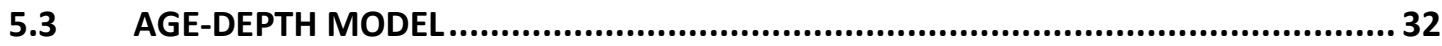

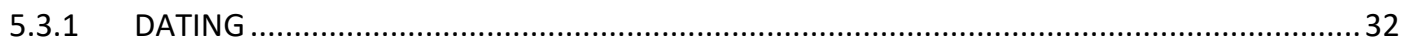

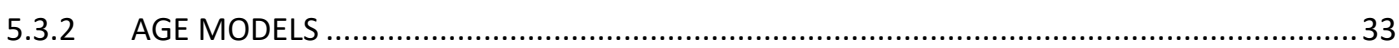

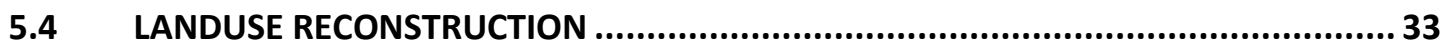

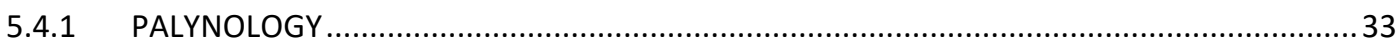

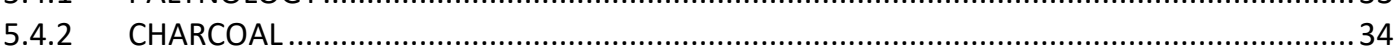

5.4.3 ANALYSIS OF ENVIRONMENTAL DNA USING DROPLET DIGITAL PCR ..............................34

5.4.4 GEO-CHEMICAL ANALYSIS - CADMIUM, TOTAL NITROGEN AND TOTAL CARBON .............36

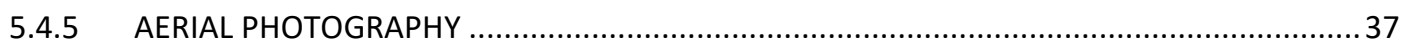


5.5 LAKE ECOSYSTEM AND WATER QUALITY RECONSTRUCTION............................ 37

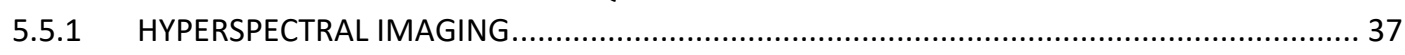

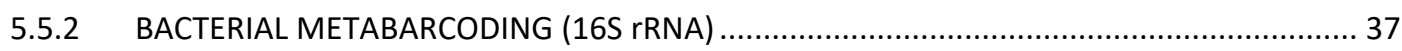

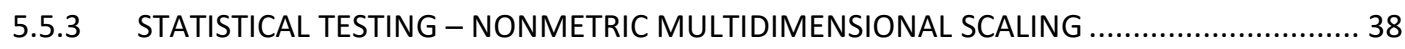

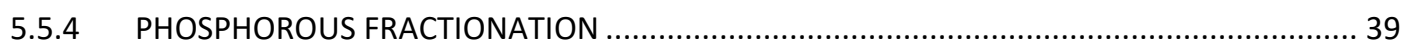

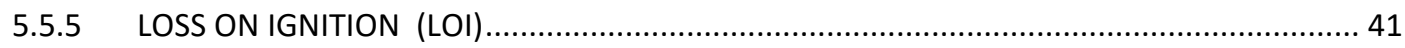

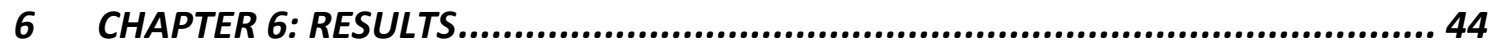

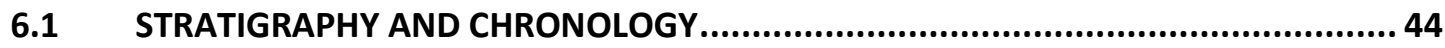

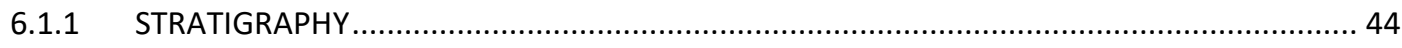

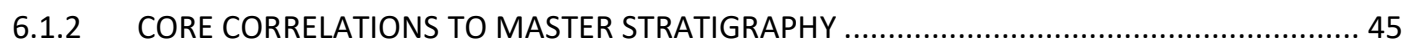

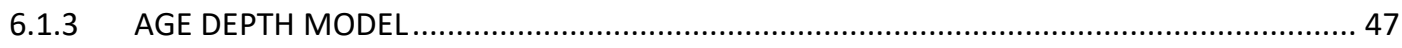

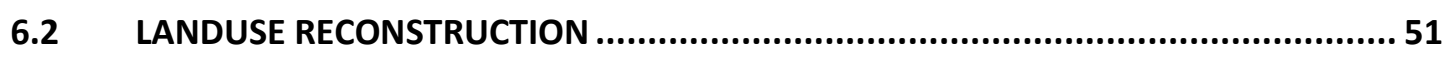

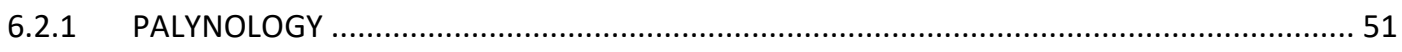

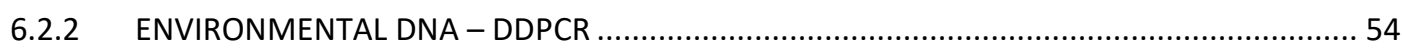

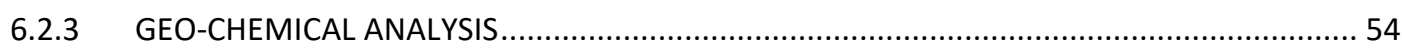

6.3 LAKE ECOSYSTEM AND WATER QUALITY RECONSTRUCTION...............................55 55

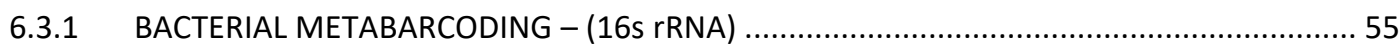

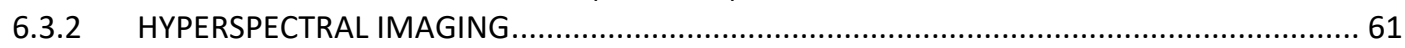

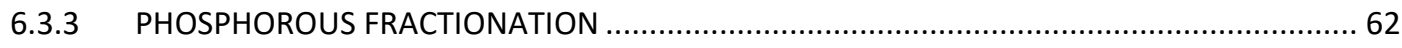

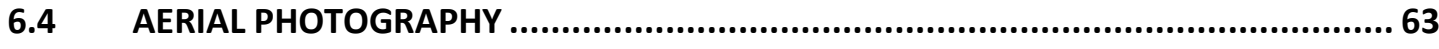

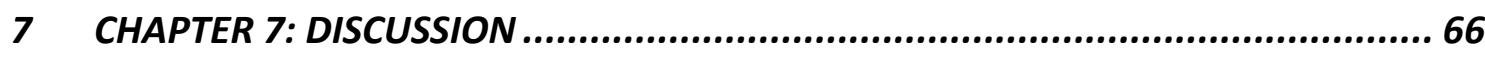

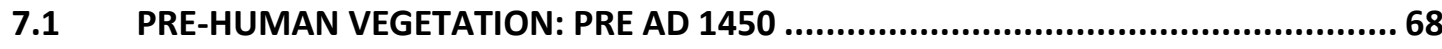

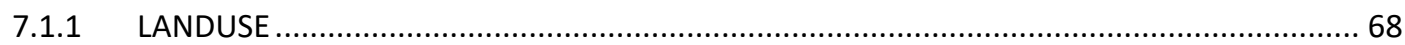

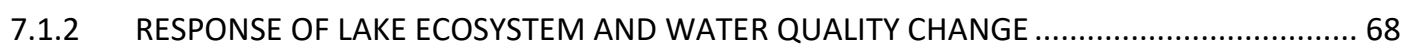

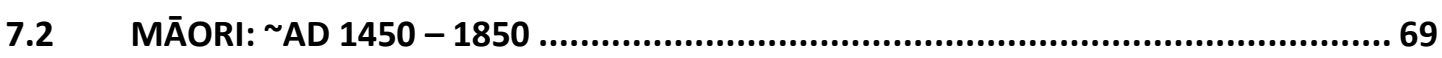

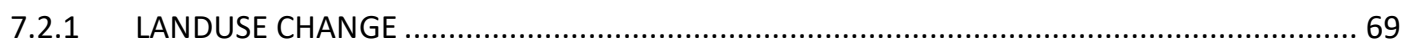

7.2.2 RESPONSE OF LAKE ECOSYSTEM AND QUALITY CHANGE ................................................. 71

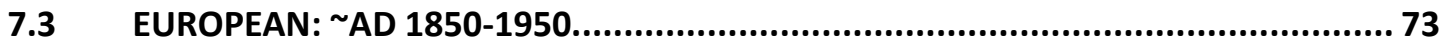

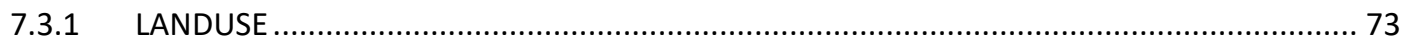

7.3.2 RESPONSE OF LAKE ECOSYSTEM AND QUALITY CHANGE TO DRIVERS OF LANDUSE CHANGE 75

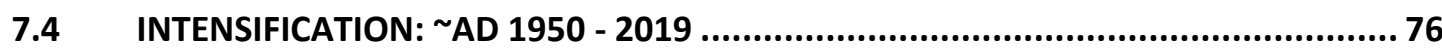

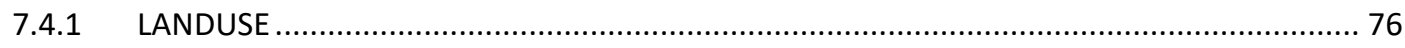

7.4.2 RESPONSE OF LAKE ECOSYSTEM AND QUALITY CHANGE TO DRIVERS OF LANDUSE CHANGE 78

7.5 ASSESSMENT OF THE EFFECTIVENESS OF RIPARIAN ZONES IN MITIGATING AGRICULTURALLY RICH NUTRIENTS 79

7.5.1 THE EFFECTIVENESS OF RIPARIAN GROWTH IN MITIGATING AGRICULTURALLY RICH

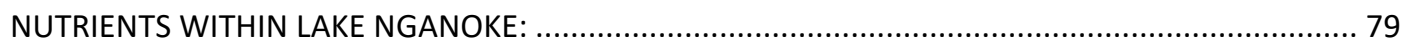

7.6 VALIDITY OF PALEO-BASED METHODS ............................................................. 81

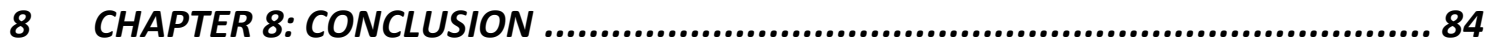

8.1 RECONSTRUCTION OF HISTORIC LANDUSE AND WATER QAULITY WITHIN LAKE

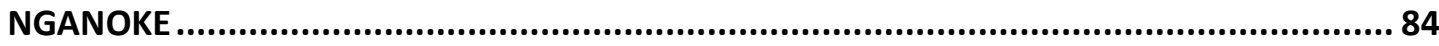

8.2 THE ABILITY OF RIPARIAN ZONES TO BUFFER NUTRIENT RICH AGRICULTURAL RUNOFF 86

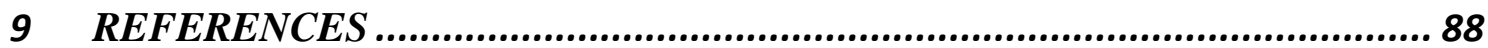

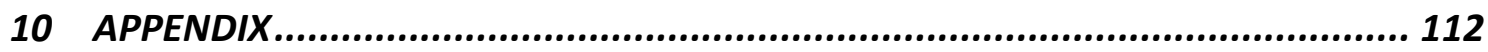

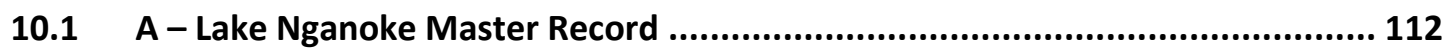


10.2 B - Full Pollen Taxonomy.

113

10.3 C - RESULTS SECTION 6.2 AND 6.3 PLOTTED ON DEPTH ... 


\section{LISTS OF FIGURES}

FIGURE 2.1: STATISTICS FOR AGRICULTURAL DIVERSIFICATION WITHIN NEW ZEALAND FROM $1961-2001$..................... 6

FIGURE 2.2: TRENDS IN 72 LAKES WATER QUALITY MEASURES OVER A 10 YEAR PERIOD (2004-2013) ........................ 9

FiguRE 4.1: LOCATION OF THE WAIRARAPA REGION IN RELATION TO NEW ZEALAND (LEFT) AND ASSOCIATED LANDFORMS (RIGHT).

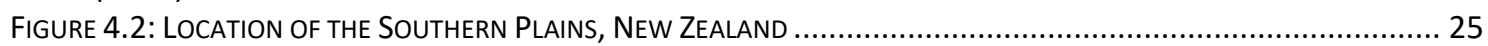

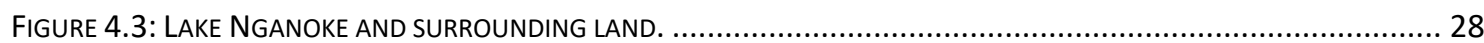

FIGURE 5.1: STRUCTURE AND SEALING SKETCH OF THE CONVENTIONAL UWITEC GRAVITY CORER. RETRIEVED FROM GONG ET

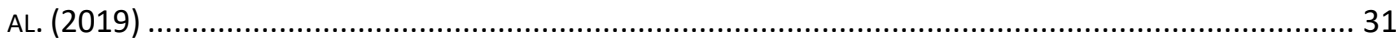

FIGURE 5.2: SEQUENTIAL EXTRACTION SCHEME USED ON LAKE NGANOKE SEDIMENTS.......................................... 41

FIGURE 6.1: STRATIGRAPHIC CHARACTERISATION (A) AND OBSERVATIONS (B) OF CORES LC1U, LC2U, LC3U AND LC6U. 45

FIGURE 6.2: CORRELATIONS OF CORES LC1U (A), LC2U (B), LC3U (C) AND LC6U (D) ..................................... 46

FIGURE 6.3: Polynomial RegreSSIONS Of CORES LC1U (A), LC2U (B) AND LC6U (C) ....................................... 47

FIGURE 6.4: ${ }^{210}$ PB EXCESS PLOTTED AGAINST DEPTHS (A) AND AGES CALCULATED USING THE CRS MODEL (B)................ 48

FIGURE 6.5: OXCAL AGE MODEL OF LAKE NGANOKE SEDIMENT DOWN CORE USING DEPTHS CORRELATED TO A MASTER CORE

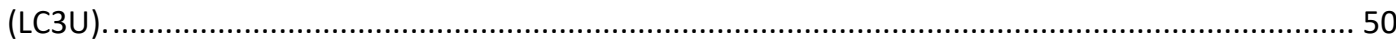

FIGURE 6.6: StRATIGRAPHY OF KEY POLLEN TAXA (SEE APPENDIX 1 FOR DETAILED STRATIGRAPHY). ............................. 53

FIGURE 6.7: DIGITAL DROPLET RUMINANT PCR OF LAKE NGANOKE SAMPLES...................................................... 54

FIGURE 6.8: GEO-CHEMICAL ANALYSIS OF CADMIUM, TOTAL NITROGEN, TOTAL CARBON AND CARBON TO NITROGEN RATIO

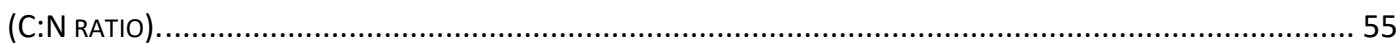

FIGURE 6.9: TAXONOMIC RICHNESS (OBSERVED ASV'S) (A) AND COMPOSITION (READS PER SAMPLES) (B) OF LAKE NGANOKE AT PHYLUM LEVEL.

FiguRE 6.10: TAXONOMIC PERCENTAGE RICHNESS (OBSERVED ASV'S) AND ABUNDANCE (READS PER SAMPLES) (B) OF LAKE

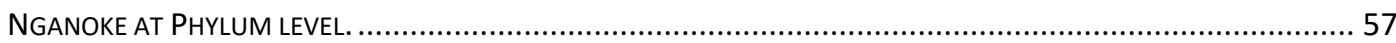

FIGURE 6.11: TWO-DIMENSIONAL NON-METRIC MULTIDIMENSIONAL SCALING PLOT DISPLAYING TAXONOMIC DIFFERENCES

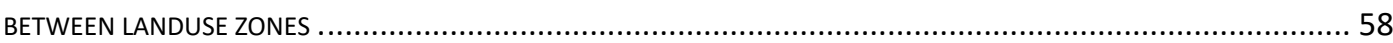

FIGURE 6.12: TAXA INDICATIVE OF CHANGES IN LAKE WATER QUALITY AND ECOSYSTEM HEALTH IDENTIFIED THROUGH

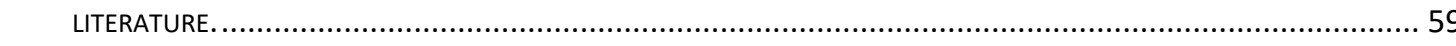

\section{7} 58

FIGURE 6.13 HYPERSPECTRAL RATIO OF THE 660/670 NM BAND (GREEN) IN LAKE NGANOKE WITH MEAN VALUE OF 1.803

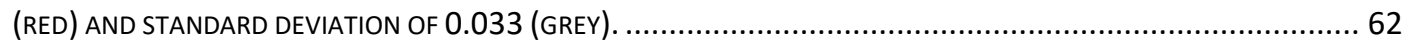

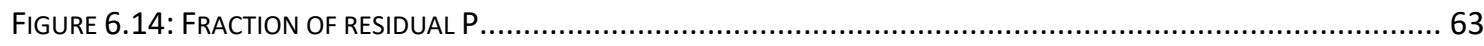

FIGURE 6.15: HISTORICAL AIR PHOTOGRAPHS OF LAKE NGANOKE (BLUE) AND RIPARIAN CHANGE (YELLOW) FROM 1944 TO

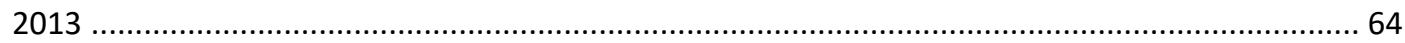

FIGURE 7.1: SUMMARY FIGURE OF LANDUSE, WATER QUALITY AND ECOSYSTEM CHANGE WITHIN LAKE NGANOKE .............67

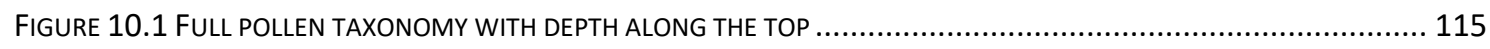

FIGURE 10.2 STRATIGRAPHY OF KEY POLLEN TAXA PLOTTED ON DEPTH ............................................................ 116

FIGURE 10.3 DigITAL DROPLET RUMINANT PCR OF LAKE NGANOKE PLOTTED ON DEPTH ...................................... 117

FIGURE 10.4 GEO-CHEMICAL ANALYSIS OF CADMIUM, TOTAL NITROGEN (TN), TOTAL CARBON (TC) AND CARBON TO

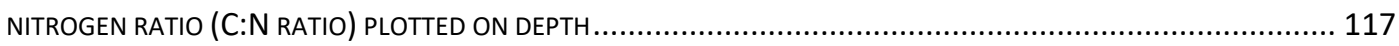

FIGURE 10.5 TAXONOMIC COMPOSITION (READS PER SAMPLES) (B) AND RICHNESS (OBSERVED ASV'S) (A) OF LAKE

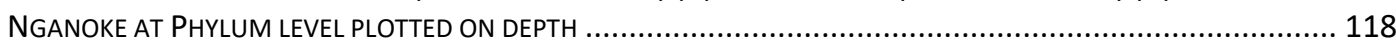

FIGURE 10.6 TAXONOMIC PERCENTAGE ABUNDANCE (PERCENTAGE OF READS PER SAMPLE) (B) AND RICHNESS (OBSERVED ASV'S) (A) OF LAKE NGANOKE AT PHYLUM LEVEL PLOTTED ON DEPTH ................................................. 119

FIGURE 10.7 TWO-DIMENSIONAL NON-METRIC MULTIDIMENSIONAL SCALING PLOT DISPLAYING TAXONOMIC DIFFERENCES

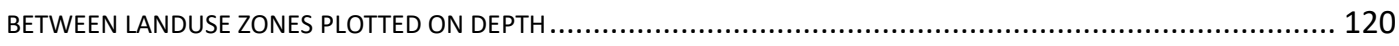

FIGURE 10.8 TAXA INDICATIVE OF CHANGES IN LAKE WATER QUALITY AND ECOSYSTEM IDENTIFIED THROUGH LITERATURE

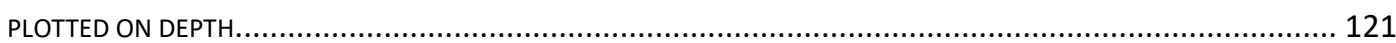

FIGURE 10.9 HYPERSPECTRAL RATIO OF THE 660/670 NM BAND (GREEN) IN LAKE NGANOKE WITH MEAN VALUE OF 1.803

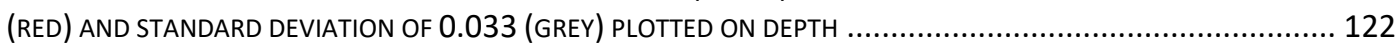

FIGURE 10.10 FRACTIONS OF RESIDUAL PHOSPHOROUS CALCULATED BY SEQUENTIAL EXTRACTION PLOTTED ON DEPTH..... 122 


\section{LISTS OF TABLES}

TABLE 1: LANDUSE CLASSIFICATION OF THE WAIRARAPA REGION............................................................ 23

TABLE 2: PB210, BomB SPIKE, CONVENTIONAL 14C AND BIO STRATIGRAPHIC AGE CONSTRAINTS FOR THE LAKE NGANOKE MASTER RECORD.

\section{LISTS OF EQUATIONS}

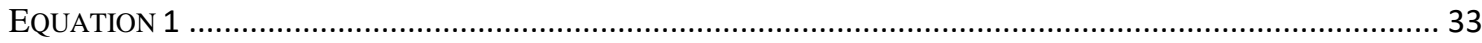

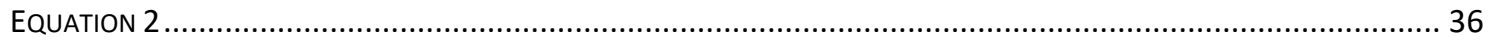

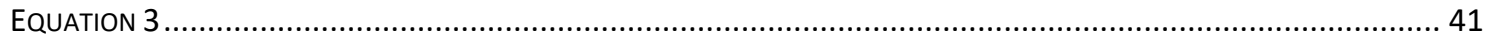

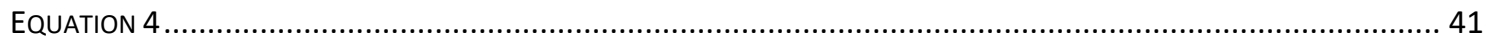

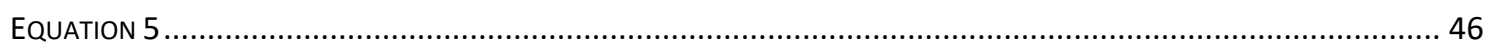

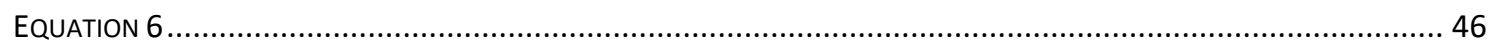

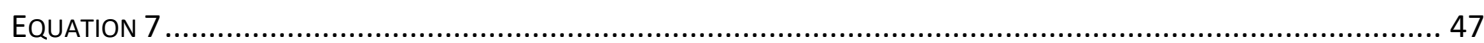




\section{CHAPTER 1: INTRODUCTION}

\subsection{MOTIVATION AND RATIONALE}

The health of lakes in Aotearoa, New Zealand is central to our environmental, economic and cultural wellbeing. In recent years there has been increasing concerns over the declining quality of freshwater (Environment, 2012). Despite these concerns, there has been no robust assessment of the water quality or ecological health of New Zealand's 3,800 (>1 hectares) freshwater lakes and over 95\% are un-monitored (Verburg et al., 2010). Furthermore, comprehensive assessment of lake ecosystems and water quality can be time consuming and costly, limiting monitoring to a select few sites. The small number of programmes that do exist are often short, spanning less than 10 years and are only implemented after the target lake has degraded (Ward et al., 1986; Burns et al., 1999a; Burns et al., 2005, 2009). Hence, the true extent of the decline from baseline natural conditions within New Zealand freshwater lakes is largely unknown. This is partly because current monitoring of lake water quality does not provide any information on baseline reference states which can be used to help set informed restoration goals (Bennion et al., 2011; Battarbee et al., 2012).

Constantly deposited over time, sediments preserve measures of historic lake health, landuse and water quality, equivalent to centuries of monitoring (Bennion et al., 2011; Battarbee et al., 2012). These data can therefore provide a continuous and high-resolution historical understanding of the lake environment and ecosystem change that is not possible with conventional methods. Consequently, the "paleo" approach offers otherwise inaccessible insights into New Zealand's freshwater issues.

Rapid expansion and improvements of the agricultural sector are seen as one of the biggest contributions to declining freshwater (Moller et al., 2008; Haggerty et al., 2009; Morgenstern \& Daughney, 2012; Foote et al., 2015; Scarsbrook \& Melland, 2015). Furthermore, nutrient overloading from increased stocking and fertilisation are directly recognised as drivers of in lake algal blooms and eutrophication (Abell, Özkundakci, et al., 2011). Improving strategies against further pollution is therefore a necessity for addressing declining water quality.

Riparian buffer zones are thought to intercept and mitigate potentially harmful nutrients from reaching fresh-water (Parkyn et al., 2003). Assessing the effectiveness of riparian 
zones, however, is often problematic, as plants can take upwards of 5 to 10 years to reach maturity, requiring years of monitoring; during which a multitude of variables must also be accounted for (Anbumozhi et al., 2005). Paleoenvironmental techniques may provide insights into pre-riparian baselines, and how lake health has changed as the vegetation has matured.

The aim of this thesis was to use paleo-based approaches and environmental reconstructions to monitor changes in lake health over a 1,000 year period, assessing the effectiveness of relatively recent (post $\sim$ AD 1944) riparian planting. This study focuses on Lake Nganoke, which is a small lake currently surrounded by low intensity farming in the Wairarapa region. The chronology of changes in landuse will be constructed to provide insight into prehuman environmental conditions, Polynesian subsistence practices, agricultural intensification methods and the establishment and development of riparian planting. Using the above identified phases (European agriculture and agricultural intensification), a record of lake water quality and ecosystem evolution will be generated. A comprehensive reconstruction of Lake Nganoke's landuse, ecosystem and water quality change will offer insights into the ability of paleoenvironmental reconstruction to assess the effectiveness of riparian buffer zones in mitigating agriculturally rich run-off.

\subsection{THESIS OVERVIEW}

The thesis has been set out in 7 Chapters. Chapter 2 presents a comprehensive review of historical landuse and water quality degradation within New Zealand. The importance of riparian zones in mitigating agriculturally rich nutrients is discussed, while the use of paleolimnology and the rationale for applying these methods is also explored. Chapter 3 presents the hypothesis and objectives. Chapter 4 provides background information on the Wairarapa region and Lake Nganoke, specifically geology, climate, vegetation, landuse and human occupation. This section will also outline the chronology of surrounding landuse change, informed by relevant literature and historical accounts. Chapter 5 outlines the methodology and methods and the rationale for why each was used. Chapter 6 highlights the findings of this research. Chapter 7 uses the results of the research to test the hypotheses identified in chapter three and discusses the findings in relation to existing literature. Chapter 8 summarises this study and provides general conclusions. 


\section{CHAPTER 2: LITERATURE REVIEW}

\subsection{FRAMING THE PROBLEM}

Degradation of water resources as a consequence of agricultural land development is not restricted to New Zealand. Internationally, advancements in agricultural practices has led to greater disparities in water quality and availability (Stoate et al., 2002; Wolfe et al., 2004; Brodie \& Mitchell, 2005). Looking to the future, increasing demand to feed a rapidly growing population will only exert greater pressure on the global environment, with increasing landuse intensification required to support this deficit (Giovannucci et al., 2012).

The agricultural sector is and has been a vital part of the New Zealand economy and culture (Quinn et al., 1993; Brown \& Stone, 2007). In the year ended June 2016, the agriculture sector alone provided approximately $6.2 \%$ of New Zealand's real gross domestic product (GDP) and $\$ 28$ billion worth of exports (Government, 2016). However, growing consumer concerns and government restrictions on pollution is forcing the agricultural industry to adopt more sustainable farming practices in order to reduce further environmental degradation and live up to NZ's clean and green reputation (Collier et al., 1995; Environment, 2004).

A leader in agricultural systems, New Zealand has the ability to develop a sustainable framework that addresses the current and future management of natural resources and agricultural production. The need therefore becomes apparent to investigate past responses to changes in agricultural intensification in order to better develop efficient agricultural systems that focus on minimising future environmental degradation (Di \& Cameron, 2002).

\subsection{CHANGING LANDUSE}

Establishing the consequences and effects of historic human influence on lake health is crucial to informing future landuse best practice within localised environments (Groffman et al., 2006; Moore et al., 2008; Bennion et al., 2011; Carmichael \& Boyer, 2016). In the case of New Zealand, three distinct landuse phases have occurred; the arrival of Polynesians/Māori ( AD 1300), the arrival of Europeans ( AD 1820) and the intensification of agriculture ( AD 1950). 
Dated roughly (AD $1250 \sim 1200$ - 1282), Polynesian settlement saw the introduction of subsistence horticulture and deforestation practices within New Zealand (McIntrye, 2002; Wilmshurst et al., 2011). Whilst the timing of initial occupancy is largely debated within academia, general consensus can be reached on the detection and validation of large-scale colonisation in $\sim \mathrm{AD}$ 1250. Archaeology and radiocarbon dating of historic sites containing both moa bones and east tropical Polynesian artefacts date settlement no earlier than AD 1270 at Wairau Bar in the top of the South Island, (Higham et al., 1999). In the case of the Wellington and the wider Wairarapa region, proof of settlement can be identified in the first few decades of the $14^{\text {th }}$ century (Sutton, 1987; McFadgen et al., 1994; Walter et al., 2017). Historical records and oral histories place importance on the modification of tropical subsistence systems to exploit the resource base of a new climate and ecology (McFadgen et al., 1994; Walter et al., 2017).

Further evidence regarding the timing of human arrival in New Zealand is provided through paleoenvironmental records of pollen and charcoal preserved by lake sediments. Lacking metal implements, Māori primarily used fire to keep tracks clear, maintain dwellings free of tall vegetation, clear sites for cultivation, and to encourage bracken (Pteridium esculentum): a major source of carbohydrates (McGlone, 1983b, 1989b; McGlone \& Wilmshurst, 1999a). While New Zealand is rich in fuel, high moisture levels make naturally occurring fires rare (McWethy et al., 2013). Therefore, periods of intense burning likely indicate the presence of people on the landscape. These events are often reflected in abrupt increases in charcoal particle influx into lake basins, departing from low and irregular baselines (Newnham, Lowe, McGlone, et al., 1998; Wilmshurst et al., 2004; Ogden et al., 2006; Abrahim et al., 2013). At the same time, a sharp decrease in tall tree pollen is coeval with an increase in light-demanding shrubs, scrub, bracken and grassland pollen (Elliot et al., 1995; Ogden et al., 2003). Furthermore, lake sediments record increases of detrital silt and sand from fire-disturbed catchments, with lake and swamp flora often changing from oligotrophic sedges (grass-like, wetland plants) to nutrient-demanding wetland plants such as raupo (Typha) (Deng et al., 2006). As a result of anthropogenic and natural burning fires, only $50 \%$ of lowland forests remained by the 1800s (Salmon, 1975; McGlone, 1989b; Ewers et al., 2006; Stevens et al., 2013).

The next identifiable landuse change, early European settlement occurred 180 years ago and saw large-scale deforestation practices for the establishment of low-density agriculture. Well documented landscape changes are easily identified in 
paleoenvironmental records through both the wide range of introduced exotic plant species and the decline of bracken, ferns and native Podocarps (Elliot et al., 1997; Elliot et al., 1998; Byrami et al., 2002; Ogden et al., 2006). Indicative of European settlement, increases in grasses (Poaceae), willow (Salix), and sheep sorrel (Rumex acetosella) are characteristic of landuse clearance for agriculture. The most significant indicator, however, is the introduction and presence of pine (Pinus) (McWethy et al., 2010)

Although present in New Zealand from the late eighteenth century, the generally accepted date for European impact on the terrestrial environment is AD 1840 (Wendelken, 1976; Newsome, 1987; Ogden et al., 2006). Following this date and until the mid-1950s, forested and swamp land was rapidly cleared in favour of low-density agriculture. The sheep industry grew from 2,760,000 in AD 1861 to more than 20,230,000 by AD 1901. By the turn of the $20^{\text {th }}$ century, 335,000 dairy cows produced a total of 9,000 tons of butter and over 5,000 tons of cheese to be exported to Europe (McLintock, 1966a). Production grew again in the 1920s, with increasing accessibility of superphosphate and the beginning of organised agricultural research paving the way for the future of New Zealand's agriculture (Wood \& Pawson, 2008).

Post AD 1950, the expansion of European agriculture as a result of technological innovations and increasing prices for farm products greatly influenced agricultural intensification within New Zealand (McLintock, 1966a; McGlone \& Wilmshurst, 1999c; McFadgen, 2003b; Moller et al., 2008). Arguably, the invention of aerial topdressing in the late 1940s was one of the largest factors responsible for this development, including the spreading of superphosphate fertiliser, pastural seed and poisoned bait from low flying aircrafts (Pike; \& Hanmore, 2017). This progression in aerial topdressing enabled applications of fertiliser and seed at greater rates per hectare. Consequently, commercial top-dressing fertilisation increased from 0 tonnes in AD 1950 to 900,000 tonnes by AD 1965, encompassing over 3.5 million hectares. Unsurprisingly, between AD 1950 and AD 1960, sheep numbers within NZ alone rose by 40\% (McLintock, 1966b; Peden, 2008). Rising prices and greater returns further intensified agricultural production as farmers had increased capital to invest in fertilisation, seeding, new machinery and the clearing of more land (MacLeod \& Moller, 2006a).

By 2015, more than 14 million hectares of land had been cleared and converted to agricultural farming (Statistics NZ, 2019), equating to roughly 50\% of New Zealand's 
current total land surface (28 million hectares). Intensification during the European era saw the growth of agricultural land from 16 million hectares in AD 1961 to 17 million hectares in AD 2001 (Figure 2.1E), before dropping to 14 million hectares by AD 2015 (Statistics NZ, 2019). Unsurprisingly, stocking rates of cattle and sheep have also dramatically changed during this period, from 82 million in AD 1961 to 95 million in AD 2001 (Figure 2.1A \& B), dipping to 38.4 million by AD 2015 (Statistics NZ, 2019). Although sheep numbers have dropped from 50 to 27 million during this period (19612015), dairy numbers have risen from 4.5 to 10.1 million, mainly due to the strong international demand for dairy products (Statistics NZ, 2019). Specifically, in the last 30 years there has been a rapid push for intensification with a $627 \%$ increase in nitrogen fertiliser applied, a 94\% increase in irrigated agricultural land and a 70\% increase in dairy cattle numbers (Statistics NZ, 2019).
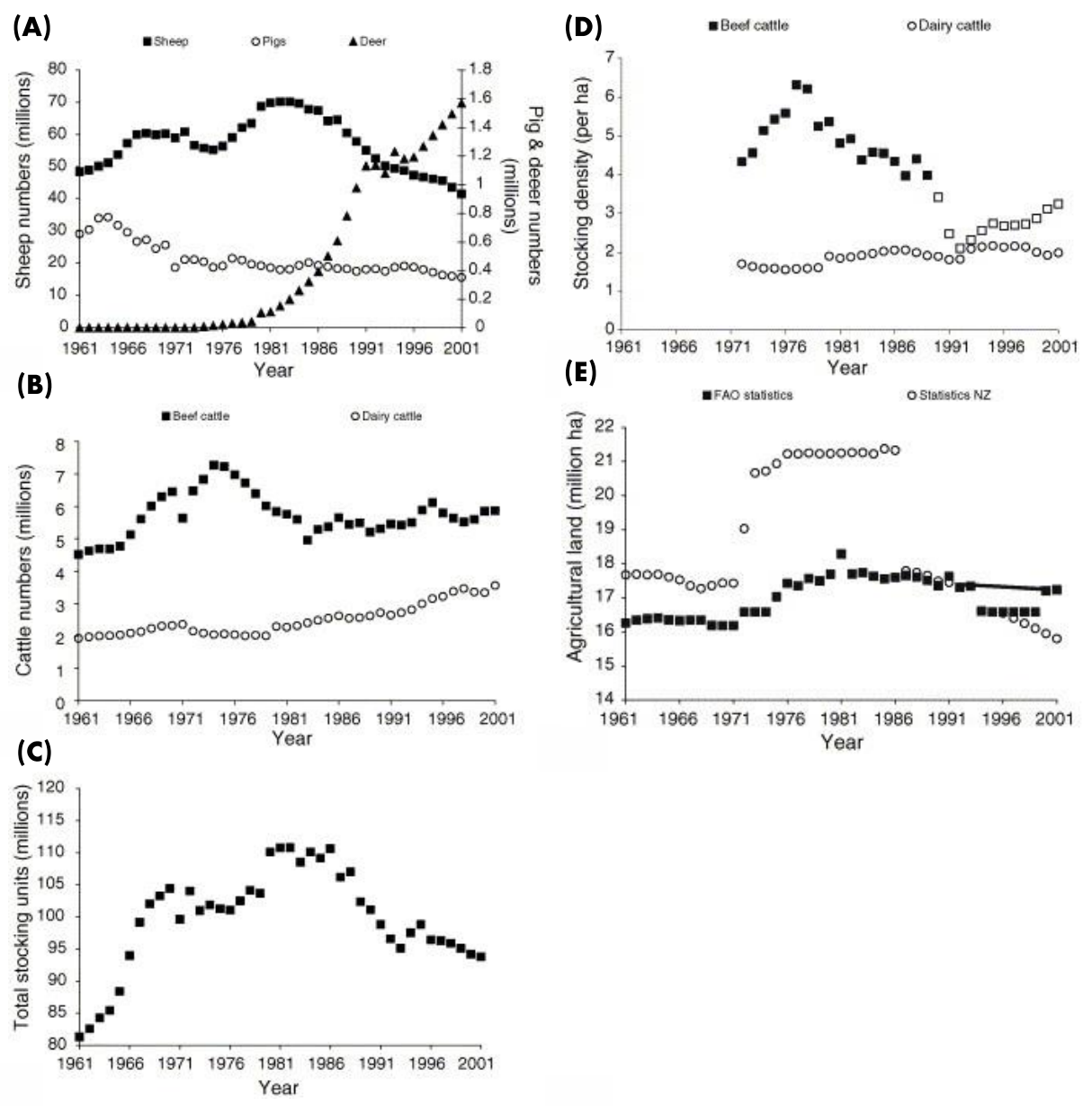

Figure 2.1: Statistics for agricultural diversification within New Zealand from 1961 - 2001 Highlighting sheep numbers (A), cattle numbers (B), total stocking units (C), stocking density (D) and agricultural land (E). Adapted from (MacLeod \& Moller, 2006a)

Based on the above literature, four clear periods of landuse within New Zealand are identified: pre-human, Māori, European settlement and agricultural intensification. Due 
to the large nature of changes within a short time period, the pressure exerted on localised environments and freshwater systems is unsurprising. It is important to note, that while these zones have been established at a national scale, variations in timescales may occur regionally. Further exploration of historical landuse changes specific to the Wairarapa Valley and Lake Nganoke are explored in Section 4.2.

\subsection{FRESH WATER DEGRADATION}

The last 180 years of European landuse intensification have resulted in a trend towards more eutrophic conditions in New Zealand's freshwater environments, greatly affecting water quality, aquatic habitats and macroinvertebrates communities (Barmuta, 2001; Collier et al., 2014). Eutrophication can be defined as excessive growth of phytoplankton caused by nutrient over-enrichment leading to imbalances in the primary and secondary productivity, and is a well-known problem in lakes (Khan \& Ansari, 2005; Yang, Wu, et al., 2008; Conley et al., 2009). While it is a naturally occurring process, eutrophication can be greatly accelerated by human activities primarily through increased rates of nutrients entering a water body.

High nutrients within a watershed can stress lake ecosystems, consequently decreasing biodiversity as dominant species and functional groups are overrun by nutrient responsive algae (Song et al., 2019). For instance, an increased input of limiting nutrients (such as nitrogen and phosphorus) into a nutrient poor lake can cause a critical transition to a eutrophic state, where nutrients and organic productivity are high and non-nutrient dependant taxa are depleted (Hall \& Smol, 2010; Lowe \& Walker, 2014). Low resistance to high nutrient turnover within sediments can also promote growths of toxic bloom forming algae such as Cyanobacteria (Paerl et al., 2001). Dramatic increases in productivity can promote anoxia in the hypolimnion, which in turn diminishes lake ecosystem function and water quality further (Liu \& Qiu, 2007; Verburg et al., 2010). The transition to an alternative stable state is often difficult and expensive to reverse or, in some cases, irreversible due to large changes in the physical or ecological properties of the system (Biggs et al., 2012; Scheffer et al., 2012).

The quality of a lake's water is a key indicator of its overall health, with a general consensus highlighting the importance of chemical, physical and microbiocidal elements (Hooda et al., 2000). More specifically, these characteristics include: $\mathrm{pH}$, temperature, dissolved oxygen, conductivity, nitrogen and phosphorous concentrations. All lakes 
within New Zealand are rated using the trophic level index (TLI), which is designed to rate bodies of water based on biological activity, water clarity and the amount of nutrients present (Burns et al., 1999b). A parameter within TLI, Chlorophyll a is often an indicator of eutrophication related to algae bloom proliferation and lake biological productivity (Burns et al., 1999b).

While there is agreement on what aspects of water quality to measure, differences on the accepted standards and the techniques are often a point of contention. Disagreement often arises over equipment, sampling strategies and lake health standards (Burns et al., 2009). Similarly, aspects that are valuable indicators for one catchments health may not be as relevant for another (Medema et al., 2003). The need therefore becomes apparent for localised understandings of the relationship between landuse and water quality when considering a lake's health (Bartram et al., 1996; Howard-Williams \& Kelly, 2003).

Despite these understandings, it is widely acknowledged that New Zealand's lake health records is vastly short and incomplete (Environment, 2006). As such, comprehensive data of lake health within New Zealand is extremely limited with only 5\% having greater than 1 years' worth of monitoring (Verburg et al., 2010). Lake Nganoke is no exception to this, having no current data on present or historic water quality. Nevertheless, there are indications that freshwater health is degrading. Observations over a 10-year monitoring programme highlight a large number of water quality indicators within 72 agriculturally dominated lakes as worsening (Figure 2.2) (Larned, 2015). While not conclusive evidence of a decline from baseline conditions, these indications of lake degradation only serve to emphasise the need for further investigations into lake health within New Zealand; research into Lake Nganoke supports this mandate. 


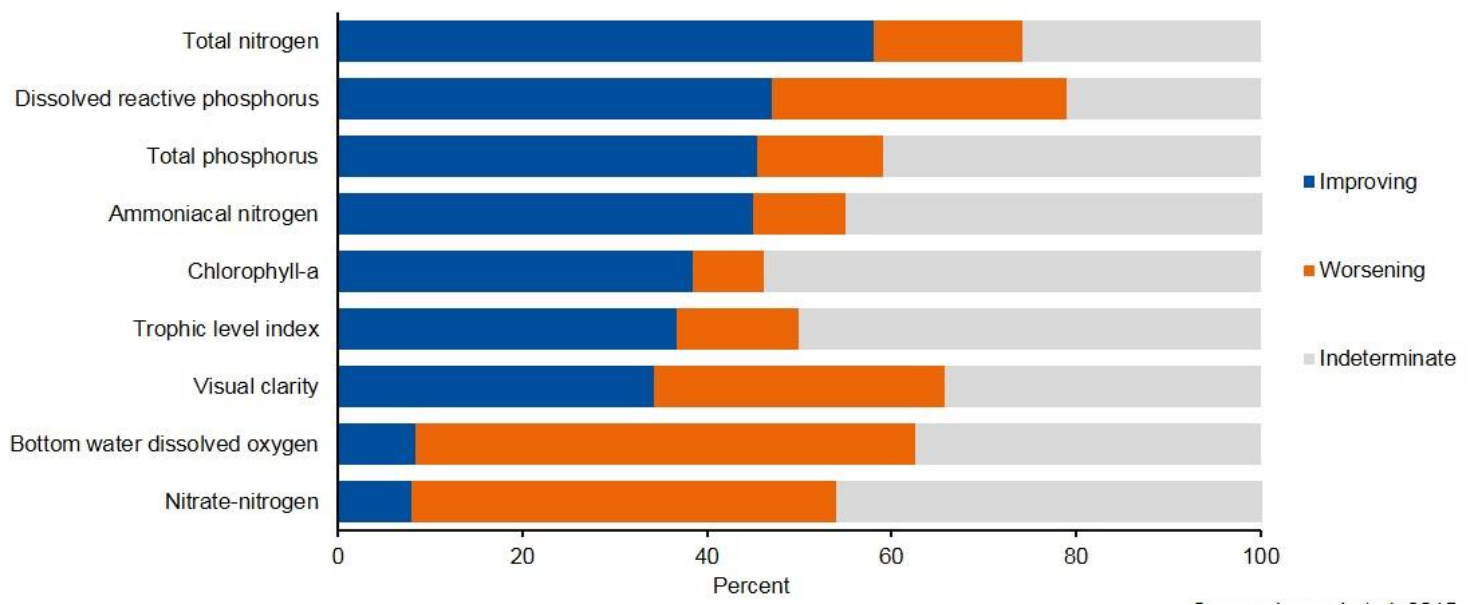

Figure 2.2: Trends in 72 lakes water quality measures over a 10 year period (2004-2013) Lake water quality is quantified as improving (blue) or worsening (orange) based on parameters (total nitrogen, dissolved reactive phosphorous, total phosphorous, ammoniacal nitrogen, chlorophyll-a, trophic level index, visual clarity, bottom water dissolved oxygen and nitratenitrogen). Retrieved from Larned (2015)

Globally, further research has linked the expansion and intensification of agricultural production with the rise of nitrogen $(\mathrm{N})$ and inorganic phosphorous $(\mathrm{P})$ nutrients within lake waterbodies (Hall \& Schreier, 1996; Hamilton \& Schladow, 1997; Elser et al., 2007). Specifically, Gillon et al. (2015) argue the need for baseline assessments in understanding how long-term changes in nutrient overloading and agricultural intensification act as nonstationary drivers of lake water quality. Nationally, studies conducted by Vant and Huser (2000) and Vincent et al. (1984) highlight the lack of timeframe covered by conventional monitoring. Crucially, measurements of baseline lake health provide a reference point for how lake ecosystems respond to landuse change, better informing future water quality management.

\subsection{AGRICULTURAL POLLUTANT MITIGATION: RIPARIAN PLANTING}

Two sources of agricultural pollution impacting freshwater bodies have been internationally recognised: point and non-point (diffuse) sources (Grant et al., 1996; Kronvang et al., 1997; Ulén \& Mattsson, 2003; Chapman et al., 2005; Heathwaite et al., 2005; Nelson et al., 2005; Chardon \& Schoumans, 2007). Point source pollution refers to identifiable locations of pipe or drain discharge of wastewater and/or sewage. Conversely, non-point pollution arises from over or under land flow, where landuse pollutants and nutrients leach into freshwater bodies (Peirce, 1998).

The majority of agricultural nutrients enter water systems through surplus runoff (nonpoint source) as it flows over or under farmland and hence is a non-point source pollutant 
(Schoumans et al., 2014). One of the most significant pathways of $\mathrm{P}$ and $\mathrm{N}$ loss in hilly and mountain areas occurs when erosion detaches soil particulates during overland flow. Conversely, leaching and artificial drainage are key nutrient pathways in flatter or less hilly areas (Chapman et al., 2005; Chardon \& Schoumans, 2007; Schoumans et al., 2014). Until the early 1990s, the majority of attention was focused on easily identifiable pointsource pollutants. Recently, research and investigations have shifted to diffuse sources, which have proven to be much more problematic to control and mitigate (Environment, 2004; Environment, 2013)

Due to a nutrient's ability to travel vast distances, the largest limitation lies in identifying and containing the source of both $\mathrm{N}, \mathrm{P}$ and/or both pollutants. A total of 83 mitigation strategies were identified from literature (Schoumans et al., 2014) and grouped into the following eight categories:

Farming System:

1. Nutrient Management

2. Livestock Management

Field System:

3. Soil Management

4. Crop Management

Landscape and Hydrological System

5. Water Management within Agricultural Land

6. Landuse Change

7. Landscape Management

\section{Ecological Management}

8. Surface Water Management

Riparian buffer zones fall within the Landscape Management category and are a preferred mitigation strategy because of their low cost and natural approach. The concept of riparian restoration has appeared within New Zealand for over 30 years, with a core focus on buffering aquatic systems from agricultural landuse (Quinn et al., 1993). Typically, the riparian zone is recognised as the vegetated strip of land ranging along streams, rivers, lakes and wetlands (Gregory et al., 1991; Martin et al., 1999; Parkyn, 2000). Holistically, it is the interface between terrestrial and aquatic environments, providing a disproportionately sizeable impact on water quality relative to its quantity of surface area (Kauffman \& Krueger, 1984; Osborne \& Kovacic, 1993; Harding, 2009). 
Two types of zones can be distinguished: 1) unsaturated, vegetated buffer zones, and 2) saturated, riparian wetlands (Schoumans et al., 2014; Hénault-Ethier et al., 2019). While academics cannot agree on the most effective composition (width and types of plant species) of riparian zones, general consensus can be found on the overall functions provided. These include: bank stabilisation, flood control, reductions in peak flow during floods, stream temperature regulation, stock exclusion (reducing bank trampling, defaecation in-stream, stock losses and waterborne illness), filtration of surface runoff reducing in-stream sedimentation and nutrification, provision of organic matter in-stream as a food source, and provision of habitat for fish spawning and adult phases of aquatic invertebrates (Kauffman \& Krueger, 1984; Lowrance et al., 1984; Osborne \& Kovacic, 1993; Collier et al., 1995; Fennessy \& Cronk, 1997; Jorgensen et al., 2000; Parkyn, 2000).

Typically, riparian zones are considered to offer efficient protection against $\mathrm{P}$ bound particles, between 41-92\% retention (Hoffman et al., 2009). However, a riparian buffer zone's effectiveness depends on many factors, such as the concentration of pollutants, slope angle, soil type and vegetation (Schoumans et al., 2014). Unsurprisingly, high concentrations of nutrient pollutants potentially stress and overload a riparian buffer zone's ability to absorb agricultural run-off (Anbumozhi et al., 2005). Likewise, steeper slope angles in lake catchments can lead to faster groundwater and overland flow movement, further exacerbating stress. The type of soil directly affects how quickly water can be absorbed (Parkyn et al., 2003). Soils that are high in clay are less permeable, while soils that are made up of large particles such as sand may drain water too rapidly for roots to effectively trap pollutants. Furthermore, soils that are more acidic have a better capacity to take up nitrogen through denitrification (Hawes \& Smith, 2005).

Concerning vegetation, plant type, density and riparian width are crucial elements to consider when implementing a vegetated buffer zone (Parkyn, 2000). Indigenous plants typically reach maturity at a later stage, providing better options in terms of future sustainability as plants require and absorb more nutrients whilst they grow. Additionally, a higher plant density and diversity is more effective at capturing pollutants (Zhang et al., 2010). Concerning width, there is very little known about the optimal size for a buffer zone to be successful. Multiple studies, however, have shown that increased buffer width results in greater sediment and phosphate elimination (Parkyn, 2004; Chow, 2012; Weaver \& Summers, 2014; Miller et al., 2016). Identifying the minimum width required for a zone to be self-sustaining is inconclusive from literature with examples ranging from 
10 to 50 m (Davis \& Meurk, 2001; Parkyn, 2004). Evidentially, a 'one size fits all' approach is insufficient with sites needing to be considered on a case by case basis (Quinn et al., 2001). As a result, riparian approaches should consider the aims of the planting, channel width, slope, vegetation type and the local surrounding environmental landuse that addresses the immediacy and overall cause of the pollution (Collier et al., 1995; Quinn et al., 2001; Reeves et al., 2004).

Timescales are also imperative when contemplating riparian mitigation (Collier et al., 1995). The results of which are time consuming and never immediate, requiring a longterm perspective and investment (Schoumans et al., 2014). In particular, water quality has been observed to worsen prior to improvements (Williamson et al., 1992; Ellison et al., 2009), with a need for realistic expectations and targets to avoid disappointment and unbiased assessment. There is, however, uncertainty about the true effectiveness of riparian planting mitigation as the majority of data comprises short-term studies that do not cover the full timescale of riparian growth or water quality degradation (Schmitt et al., 1999; Liu, Zhang, et al., 2008). Historically, the majority of riparian based studies within New Zealand focus on comparisons between streams or lakes with already established riparian zones against those where there are none. Focus needs to be shifted to consider the changes in lake ecosystems pre, post and during riparian establishment to truly understand the temporal relationship in a riparian zone's ability to mitigate pollutants. Through paleoenvironmental reconstruction it may be possible to assess the efficacy of riparian planting in promoting lake health at a singular site across the pre- and post-planting spectrum.

\subsection{USE OF PALEOLIMNOLOGY}

Paleolimnology and paleoenvironmental reconstructions are recognised tools that inform future conservation management by quantifying how current lake ecosystem and water quality diverge from pre-human baselines and environments (Zhao et al., 2006; Rawlence et al., 2014; Lyver et al., 2015; Waters, 2018). Constantly deposited over time, sediments preserve measures of lake life, landuse and water quality, equivalent to centuries of monitoring (Smol, 1992). Examining these sediments can potentially provide detailed documentation and chronology of a lake's history, offering insight into the relationship between drivers of change (both natural and anthropogenic) and measures of lake ecosystem response simply not possible through current monitoring (Davidson \& Jeppesen, 2013; Hilt et al., 2017). 


\subsubsection{DRIVERS OF LAKE ECOSYSTEM AND WATER QUALITY CHANGE}

The use of paleolimnological data to identify baseline conditions largely depends on the extent to which past human landuse can be separated from natural forcing within lake sediments (Leavitt et al., 2009; Bennion et al., 2011; Mills et al., 2017). Pollen grains and plant macrofossils are one example of a proxy within lake sediments that provide insight into anthropogenic impacts on the land. Typically, pollen and spores are dispersed by wind or insects, with the surplus that is not used in reproduction accumulating in environments such as lake sediments (Seppä \& Bennett, 2003). The overall taxonomic assemblage of pollen is therefore often reflective of the surrounding vegetation of a lake, with specific indicator taxa likely representative of anthropogenic influence (Birks et al., 1976; Manny et al., 1977; Sanger, 1988; Chen \& Wu, 1999; McGlone \& Wilmshurst, 1999d).

Furthermore, charcoal peaks potentially distinguish between periods of natural and anthropogenic burning for land clearance, complemented by changes observed in pollen records (taxa such as Pteridium) (Patterson III et al., 1987). An increase in the magnitude and frequency of charcoal in stratigraphic records linked with changes in recognised indicator pollen (such as exotic taxa Pinus spp and Salix) are considered strong evidence for both Polynesian and European anthropogenic influence within New Zealand (McGlone, 1983a; Bussell, 1988; Page et al., 1994; Elliot et al., 1998; McGlone \& Wilmshurst, 1999d).

Charcoal fragments also provide insight into the proximity of landuse through the identification of past fire regimes at local and regional scales (Charles et al., 1987; Empson et al., 2002; Cohen et al., 2005). Charcoal is typically split into two groups based on particle size: microscopic $(<125 \mu \mathrm{m})$ or macroscopic $(>125 \mu \mathrm{m})$ charcoal (Turner et al., 2004). Microscopic charcoal travels farther due to its smaller size and is therefore used as a proxy for regional fires (McGlone \& Wilmshurst, 1999d; Turner et al., 2004), while macroscopic charcoal travels shorter distances due to its larger size and is used as a proxy for local fires (Turner et al., 2004). The size of charcoal fragments offers a unique insight into the likely proximity of nutrient and sediment flux into lake systems, consequently driving lake ecosystem change.

Further insight into the nature of sedimentation and erosional material entering a lake can be provided through chemical and mineralogical analyses such as carbon to nitrogen 
ratios $(\mathrm{C}: \mathrm{N})$, sediment grainsize and core density measurements. $\mathrm{C}: \mathrm{N}$ ratios indicate the origin of organic material within a lake, whether it be terrigenous in nature or the result of in-lake productivity (Thornton \& McManus, 1994; Kaushal \& Binford, 1999). Changes in grainsize and density (often informed by computerized tomography (CT)) are indicative of changes in the relative abundance of terrigenous and allogenic sediment and consequently can provide a proxy for erosion in the lake catchment (King et al., 1982; Håkanson \& Jansson, 1983; Kashiwaya et al., 1987). Largely recognised as potential drivers of lake ecosystem and water quality change, changes in sedimentation rate are most often associated with the abundance of terrigenous sediment (Heathwaite, 1994; Davies et al., 2005). Sedimentation rates increase when there is more erosion in the lake catchment. Alternatively, if sediment remains primarily autogenic then increases in sedimentation rate may reflect an increase in productivity.

Another element found within lake sediments, cadmium bioaccumulates in soils as a result of super phosphate application and hence may provide a proxy for fertilisation, and agricultural intensification. While increases of cadmium within soil as a result of superphosphate fertilisation is widely documented (Taylor, 1997; Gray et al., 1998; McDowell et al., 2013), within lakes, however, cadmium measurements are primarily interpreted as contamination of heavy metals within surface sediments (Roberts, 1981; Sindayigaya et al., 1994; Sander et al., 2013; Foote, 2014; Salmanzadeh, 2017; Taylor et al., 2017). This thesis therefore aims to investigate the use of cadmium as a proxy for superphosphate application downcore, evaluating the element's capability to characterise historical intensification of agriculture within Lake Nganoke's catchment.

\subsubsection{MEASURES OF LAKE WATER QUALITY AND ECOSYSTEM CHANGE}

Measures of lake ecosystem and water quality within paleo records have traditionally involved diatoms and chironomid analyses, as opposed to the novel approach of Environmental DNA (eDNA) proposed within this thesis (Hall et al., 1999; Sayer et al., 1999; Langdon et al., 2006). Whilst time consuming to conduct, chironomid surveys are considered one of the best indicators of a lake's overall ecosystem health. Chironomid assemblages can be used to assess salinity, water depth, aquatic productivity, oxygen levels, lake acidification, pollution and temperature (Svensonn \& Leonardson, 1996; Lotter et al., 1998; Rosén et al., 2001). Similarly, diatoms are also micro-organisms that can be used to reconstruct changes within a lake's internal $\mathrm{pH}$ and nutrient loading 
(Bradbury, 1971; Smol, 1985; Frey, 1988; Lotter et al., 1998; Shumate et al., 2002; Bjerring et al., 2009).

A relatively new technique, eDNA from sediment has been used to quantify historical abundance of organisms, including bacterial communities, microbes, aquatic macrophytes, and invertebrates. As certain groups react differently to outside factors such as light, temperature and nutrient conditions, the abundance of bacteria, for instance, can be indicative of environmental conditions and changes within a lake or catchment (Pedersen et al., 2013; Thomsen \& Willerslev, 2015; Lim et al., 2016). Traditionally, bacteria have been identified using time consuming microscope techniques not suitable for paleo-reconstruction from sediment cores. Recent advancements, however, in highthroughput DNA sequencing (HTS) technology and the establishment of taxonomic reference databases now allows eDNA to be used to quantify bacterial communities from sediment cores (Parducci et al., 2017). The 16S ribosomal RNA (16S rRNA) gene is now a widely used genetic marker for bacterial taxonomic identification and is perfect for classifying ecosystem changes archived by lake sediments (Shaw et al., 1999; Domaizon et al., 2017; Tse et al., 2018).

Bacterial taxa also have the potential to reflect the biotic or abiotic state of lake ecosystems and therefore provide evidence for the impacts of environmental change (De Caceres et al., 2016). Often defined as 'indicator taxa', these subsets of the bacterial community provides an alternative to sampling the entire community and are particularly useful in long term monitoring (De Cáceres et al., 2012). Issues arise over how to assess and define taxa most representative a lake ecosystem, as each lake environment has the potential to be completely different. Traditionally, paleolimnology studies target taxa for which well-established responses to certain conditions or clear functions have been established by previous research.

Often limiting the habitat for other organisms, cyanobacteria are an example of a recognised indicator taxa for poor water quality (Catherine et al., 2013; Chrapusta et al., 2015). Members Cyanobacteria are known bloom formers, which live in lake surface waters often blocking light penetration to other organisms that depend on photosynthesis. Furthermore, Cyanobacteria produce dangerous toxins that are measured attributes in the Ministry for the Environment National Policy freshwater management scheme (NPS-FM) for human health and recreation; with high levels of toxins often signifying a degradation 
of water quality (Greenfield et al., 2014). Cyanobacteria as an indicator taxon are therefore often representative of freshwater degradation, likely the result of increasing nutrients stimulating growth (Fay, 1992).

Other documented indicator taxa include Atribacteria, Nitrospirae and Proteobacteria. Atribacteria thrive in anaerobic environments and can therefore be indicative of increased stratification within a lake and reduced oxygen via increasing productivity (Nobu et al., 2016). Nitrospirae have known nitrate oxidising and sulphate reducing members and may provide a nursery effect for other nitrogen-limited bacteria (Kachiuru, 2013; Schneider et al., 2013). Proteobacteria include a wide variety of pathogenic genera, many of which are free living and/or are responsible for nitrogen fixation (Young, 1992; Van Dommelen \& Vanderleyden, 2007). Examples of these genera include the class Alphaproteobacteria that can grow at very low levels of nutrients (Smith et al., 2013), Deltaproteobacteria that predate on other bacteria (Schwarz et al., 2008) and Gammaproteobacteria that have important denitrifying capabilities (Cramer et al., 2011).

The ability of eDNA reconstruction also has the potential to provide insight into historic stocking rates. Traditionally, reconstructions of faecal pollutants within lake sediments have been restricted to Bacteroide markers associated with ruminant animals (ruminant bacteria) such as sheep and cows. While ruminant presence through the use of polymerase chain reaction is recognised, quantification of stocking rates are not (Bofill-Mas et al., 2006; Hamza et al., 2011; Rusiñol et al., 2016). Whilst relatively unstudied, there is potential for Digital Droplet Polymerase Chain Reaction (ddPCR) to quantify concentrations of ruminant gut bacteria found within lake sediment (Hindson et al., 2011). Through the use of Poisson distribution-based statistics, the target DNA's concentration (in this case ruminant faecal biomarkers) can be calculated within a sample (Hindson et al., 2011). This provides a quantified 'number of copies' per sample that could potentially demonstrate changes in DNA concentration downcore. The potential therefore is to use replications of ruminant gut flora DNA as a proxy for changes in stocking rates within Lake Nganoke's catchment.

Another significant component of lake ecosystems and water quality, phytoplankton are the foundation of aquatic productivity, providing integral environmental services through carbon/nitrogen fixation and oxygen production (Yackulic, 2017). Chlorophyll a exists in almost all photosynthetic organisms as the primary pigment used to absorb light in the 
violet, blue and red wavelengths of the visible portions of the photoelectric spectrum (Liu, Lauterbach, et al., 2008). Consequently, colour spectrometry from hyperspectral imaging of sediment cores have been widely used to provide a high resolution for chlorophyll a in sediments. Provided that the chlorophyll a can be attributed to algae then the scanning provides a high resolution proxy for autogenic productivity. Evidence within literature can be seen most notably in measurements of the reflectance trough related to Chlorophyll a and its diagenetic products at 660-670 nm (Rein \& Sirocko, 2002; Grosjean et al., 2014; Butz et al., 2017).

Internal nutrient loading plays a vital role in promoting excess biological growth within lake systems (Burger et al., 2008). Primary productivity in lake systems is strongly limited by nutrient availability, with the role of phosphorous $(\mathrm{P})$ in controlling lake water quality and ecosystem growth well established (Giresse et al., 1994; Wetzel \& . 2001; Mankin et al., 2007; Zhang et al., 2015; Smith et al., 2016). P loading within lakes can be split into six fractions $\left(\mathrm{NH}_{4} \mathrm{Cl}-\mathrm{P}, \mathrm{BD}-\mathrm{P}, \mathrm{NaOH}-\mathrm{rP}\right.$ and $\mathrm{NaOH}-\mathrm{nrP}, \mathrm{HCl}-\mathrm{P}$, Res-P, Total $\left.\mathrm{P}\right)$, all of which have the potential to be mobile during different conditions (Penn et al., 1995). However, the assessment of $\mathrm{P}$ fluctuations within a lake system is often complicated as the mobility of fractions within sediments may obscure the role nutrient loading plays in controlling lake health. While measurements of $\mathrm{P}$ loading within surface sediments is well documented (Jensen et al., 1992; Christophoridis \& Fytianos, 2006; Waters, 2016), the degree to which $\mathrm{P}$ fractions can be applied down core as an indicator of paleo nutrient cycling is largely unknown (Zhu et al., 2013; Lü et al., 2016). Generally considered the least mobile fraction, residual $\mathrm{P}$ (Res-P) is the most likely fraction to be indicative of nutrient cycling at the time of sediment deposition because it is unlikely to be mobile within the sediment pile. As such, this thesis pioneers the novel approach of applying the phosphorous residual fraction down core as a proxy for paleo-primary production.

\subsubsection{THE IMPORTANCE OF DATING LAKE SEDIMENTS}

The strength of a paleo reconstruction greatly depends on the accuracy of sediment chronology (Zolitschka, 1991; McGeehin et al., 2001; Gamrod, 2009). Several methods can be used to establish a time scale, with the most common including the radioactive decay of lead $\left({ }^{210} \mathrm{~Pb}\right)$ (half-life of $22.3 \mathrm{yr}$.) (Appleby \& Oldfield, 1978a; Von Gunten \& Moser, 1993) and conventional radioactive decay dating of Carbon $\left({ }^{14} \mathrm{C}\right)\left(\mathrm{t}_{1 / 2}=5730 \mathrm{yr}\right.$. $)$ (Hajdas et al., 1995). Sedimentary records can therefore be correlated by authenticating 
sediment profiles with absolute dates, with further synchronisation provided through records of pollen stratigraphy.

${ }^{210} \mathrm{~Pb}$ is widely used to provide chronology over the last century (Oldfield \& Appleby, 1984; Evans, 1991; Arnaud et al., 2006). The Constant Rate of Supply (CRS) model is the most commonly used method of ${ }^{210} \mathrm{~Pb}$ dating because its assumptions are met in the widest variety of depositional settings (Appleby, 2008). While the CRS model assumes a constant rate supply of fallout ${ }^{210} \mathrm{~Pb}$, allowing for sedimentation rate to vary through time. Isochrons derived from ${ }^{137} \mathrm{Cs}$ or biostratigraphy are used to validate ${ }^{201} \mathrm{~Pb}$ dating models.

Radiocarbon dating $\left({ }^{14} \mathrm{C}\right)$ is the most widely used dating technique for samples younger than c.50,000 years that contain sufficient organic matter (Björck \& Wohlfarth, 2002; Howarth et al., 2013). Dating using this technique measures the ratio of remaining ${ }^{14} \mathrm{C}$ to the unchanged ${ }^{12} \mathrm{C}$ to see how long it has been since the material's source died. ${ }^{14} \mathrm{C}$ samples require calibration because concentrations of ${ }^{14} \mathrm{C}$ in the atmosphere have varied through time. Samples post AD 1950 often referred to as 'bomb spike carbon' due to increases in ${ }^{14} \mathrm{C}$ concentrations in the atmosphere post nuclear testing (Broecker et al., 2001). Conventional and bomb spike ${ }^{14} \mathrm{C}$ therefore require separate calibration standards as outlined further in Section 5.3 


\section{CHAPTER 3: RESEARCH HYPOTHESES AND OBJECTIVES}

\subsection{RESEARCH HYPOTHESES}

This thesis aims to reconstruct environmental change at Lake Nganoke using paleolimnological methods and examine anthropogenic impact on the lake ecosystem and water quality over the last 1000 years. Specific attention is given to the ability of riparian zones to buffer lake ecosystems against the deleterious impacts of nutrient rich runoff from land use intensification. To achieve this aim, sediment cores from Lake Nganoke were studied to address the following research hypotheses:

1) Anthropogenic landuse intensification in Lake Nganoke's catchment has resulted in ecosystem change and a stepwise decrease in water quality from a pre-human baseline, through Māori subsistence, European agricultural and intensification.

2) The riparian zone around Lake Nganoke has buffered lake water quality against intensification of agriculture.

\subsection{OBJECTIVES}

The testing of these hypotheses require four objectives to be achieved. These are:

1. Use historical information and paleo environmental reconstruction to develop a chronology of pre-human, Māori, European and agricultural intensification in Lake Nganoke's catchment. Specifically, this objective will include a highresolution (sub-decadal) record of agricultural intensification over the last 180 years.

Objective one will involve pollen, charcoal, ICP AES, ddPCR and radiometric dating approaches.

2. Develop a paleo reconstruction of lake water quality, ecosystem evolution and nutrient loading during the above identified phases within Lake Nganoke.

Objective two will involve eDNA, hyperspectral scanning, phosphorus chemistry and ICP-MS approaches 
3. Assess the relationship between drivers of landuse change and measures of lake water quality and ecosystem integrity over the history of Lake Nganoke.

Objective three will involve a nonmetric multidimensional scaling (NMDS) based on Bray-Curtis distance and applied in RStudio

4. Investigate the establishment and development of riparian planting as a mitigation strategy against agriculturally rich nutrients.

Objective four will use historical aerial photographs and records of water quality identified within objective two 


\section{CHAPTER 4: STUDY SITE}

\subsection{PHYSIOGRAPHIC PROPERTIES}

Encompassing an area of $8,423 \mathrm{~km}^{2}$, the Wairarapa is a region known for its wide valleys, rolling hill country and rugged coastline. The region is located on the South Eastern Corner of the North Island, bordered by the Pacific Ocean in the East, the Tararua district in the North and the Rimutakas and Tararua Ranges in the west (Figure 3). The term 'Wai'ra'rapa' translates to "Land of Glistening Waters", with the region aptly named after the waters of Lake Wairarapa, situated at the bottom of the Wairarapa Plain (Fallon, 2015).
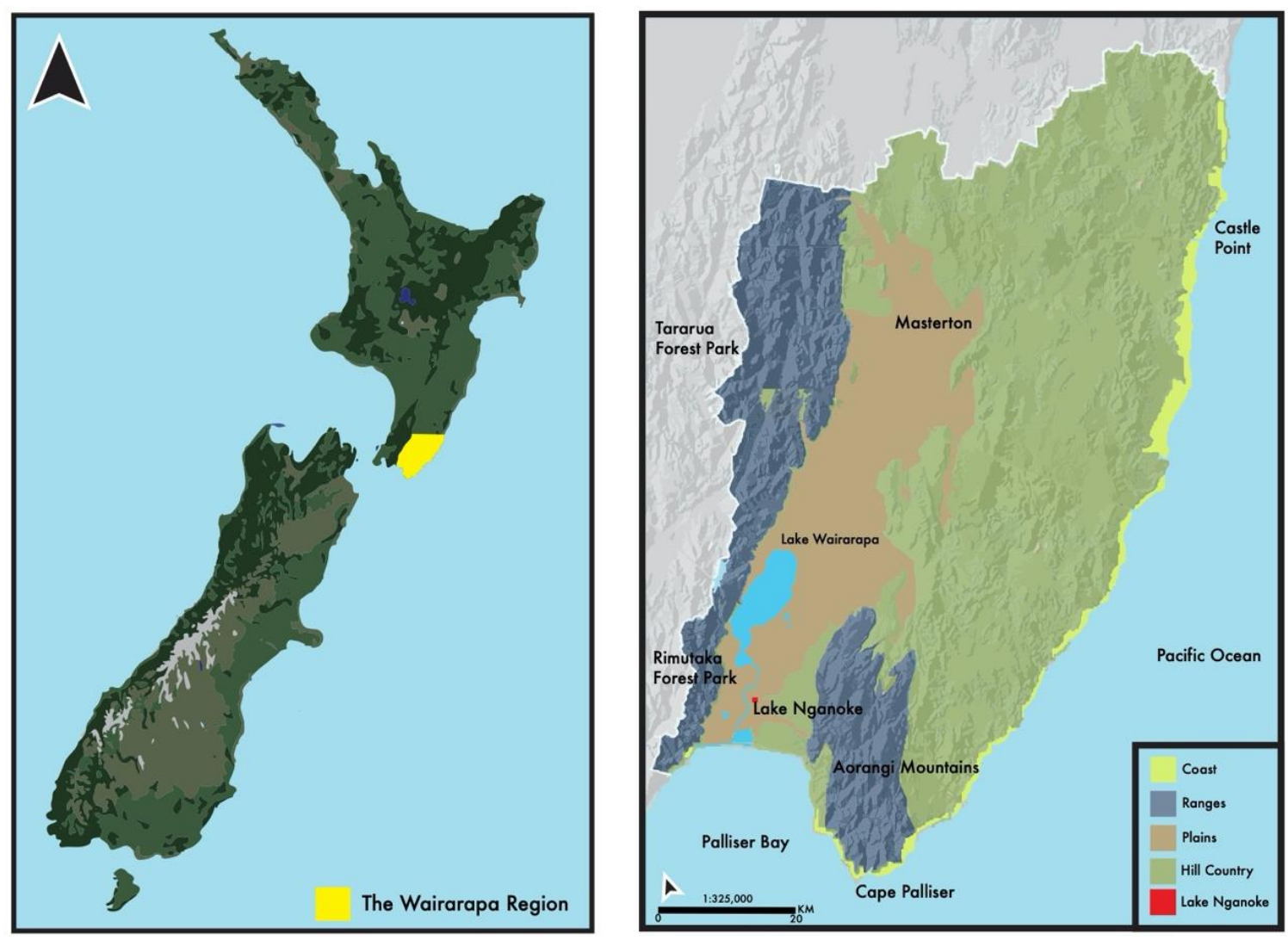

Figure 4.1: Location of the Wairarapa region in relation to New Zealand (left) and associated landforms (right).

Adapted from Miskell (2010)

Historically, the southern end of the region was inundated by water with Lake Wairarapa once a shallow marine extension of Palliser Bay (Leach \& Anderson, 1974; Kamp, 1992; Hines et al., 2013)., At the end of the postglacial marine transgression, maximum infiltration inshore of the extension was reached sometime during $\sim 7 \mathrm{kyr}$ BP (Leach \& Anderson, 1974; Heath, 1979). Subsequently, the lower Wairarapa valley developed into an extensive estuary with the Ruamahanga river prograding south until 3.5-3.1 kyr. BP. At this time, the river mouth moved north-west, settling into the main water body that 
would eventually become Lake Wairarapa, a freshwater riverine-lacustrine complex completely separate from the sea (Leach \& Anderson, 1974; Leach, 1984; Trodahl et al., 2016b). Lake Wairarapa is the largest wetland system in the lower North Island, and combined with its associated wetlands they are now considered to be of national and international importance (Myers et al., 2013; Aotearoa, 2019).

The Wairarapa area has four distinct landforms: Torlesse greywacke ranges (the Tararuas/Rimutakas ranges on the western periphery and the Aorangi ranges on the southeastern). The ranges form the highest relief in the area, measuring some $1500 \mathrm{~m}$ in height above sea level (Guggenmos et al., 2011). Separated from the Wairarapa Coast by hill country, extensive plains run from the north of Masterton to Palliser Bay (Figure 4.2). Occupying roughly $20 \%$ of the Wairarapa, the plains consist of thick late Quaternary alluvial deposits originating from the surrounding hills and ranges (Begg et al., 1996). Broadly subdivided into two, the northern plain comprises flat, gently undulating to rolling land, while the southern planes are dominated by the lake and surrounding wetland (Miskell, 2010). The majority of Wairarapa townships (Featherston, Greytown, Carterton, Masterton) are located within the northern plain. In comparison to the ranges, the northern and eastern hills reach heights of 1,000 $\mathrm{m}$ above sea level and consist of an assortment of Cretaceous and Cenozoic sandstone, mudstone and limestone (Lee et al., 2002).

The area is tectonically active with predominantly strike slip faulting in the region, including the Wairarapa fault running along the western side of the plains. The Wellington and Wairarapa region are two of the most earthquake-prone regions in New Zealand with four recorded quakes greater than magnitude 7 sine record keeping began (Rafferty, 2009; King, 2015). Furthermore, the Wairarapa fault has produced the largest earthquake (magnitude 8.2 in 1855) in New Zealand history. This greatly affected the region; the land rose up to $6 \mathrm{~m}$ in most places within the Wairarapa, while lateral movement was up to $18 \mathrm{~m}$ in some places (Lee \& Begg, 2002).

The soils of the Wairarapa can be classified according to their potential for landuse capability (Table 1) (A.K. Booth, 1969; Fallon, 2015). Class 1 soils are defined as free draining, easily cultivated, silt loam soils on river flats and terraces. These versatile soils are mainly used for intensive agriculture and only have limitations of flooding near major rivers. Class 2 soils are limited by drainage, occur predominantly on terraces and plains 
and are highly suited for agricultural landuse. Class 3 are soils either Orthic Brown or Sand (low water holding capacity) or Rendzic Melanic (limestone) soils all of which are highly permeable. Class 4 and 5 are the predominant land type within pastoral hill country. Formed from siltstones, Class 4 are typically defined as brown silt and sand in regions of moderate to well distributed rainfall. Class 6 soils are described as steep land and, mainly occurring in the foothills of the Aorangi and Tararua Ranges. Highly erosive, these soils are not suitable for any form of agricultural landuse. Within the region encompassing Lake Nganoke, the landuse is predominantly Class 2, and supports extensive sheep and beef farming.

Table 1: Landuse classification of the Wairarapa region.

Adapted from (Fallon, 2015)

\begin{tabular}{|c|c|c|c|c|c|}
\hline $\begin{array}{l}\text { Landuse } \\
\text { Capability } \\
\text { Class }\end{array}$ & $\begin{array}{l}\text { Major } \\
\text { Limitation }\end{array}$ & Landform & Major Landuse & Soil Order & $\begin{array}{l}\text { Area } \\
\text { (Hectares) }\end{array}$ \\
\hline 1 & Flooding & Plain & $\begin{array}{l}\text { Horticulture, } \\
\text { cropping, } \\
\text { dairying }\end{array}$ & Recent & 36000 \\
\hline 2 & Drainage & $\begin{array}{l}\text { Plain and } \\
\text { terrace }\end{array}$ & $\begin{array}{ll}\text { Dairying, } & \text { dairy } \\
\text { support, } & \text { lamb } \\
\text { and } & \text { cattle, } \\
\text { finishing, } & \\
\text { viticulture } & \\
\end{array}$ & Grey Pallic & 140000 \\
\hline 3 & Moisture & $\begin{array}{l}\text { Terrace, } \\
\text { rolling } \\
\text { land, dune }\end{array}$ & $\begin{array}{l}\text { Dairying, dairy } \\
\text { support, lamb } \\
\text { and } \\
\text { finishing, } \\
\text { cropping, } \\
\text { viticulture }\end{array}$ & $\begin{array}{l}\text { Orthic } \\
\text { Brown, } \\
\text { Sand. } \\
\text { Rendzic } \\
\text { Melanic }\end{array}$ & 24000 \\
\hline 4 & $\begin{array}{l}\text { Slight } \\
\text { erosion and } \\
\text { moisture }\end{array}$ & $\begin{array}{l}\text { Rolling to } \\
\text { easy hill }\end{array}$ & $\begin{array}{l}\text { Dairy support, } \\
\text { Sheep and cattle } \\
\text { breeding and } \\
\text { finishing }\end{array}$ & Brown & 240000 \\
\hline 5 & $\begin{array}{l}\text { Moderate } \\
\text { erosion and } \\
\text { serious } \\
\text { moisture }\end{array}$ & $\begin{array}{l}\text { Easy to } \\
\text { steep hill }\end{array}$ & $\begin{array}{l}\text { Sheep and cattle } \\
\text { breeding }\end{array}$ & Brown & 220000 \\
\hline 6 & $\begin{array}{l}\text { Serious } \\
\text { erosion }\end{array}$ & $\begin{array}{l}\text { Very steep } \\
\text { hill }\end{array}$ & $\begin{array}{l}\text { Exotic forestry, } \\
\text { native bush }\end{array}$ & Raw & 160000 \\
\hline
\end{tabular}

Prior to human arrival, the Wairarapa vegetation mostly consisted of conifer-broadleaf and beech forest (Hill, 1963b; Wardle, 1991), with elevations above the tree line dominated by scrub and tussock (McGlone, 1989b). Burnoff from Polynesian settlers and natural fires left large areas of grass, fern and scrubland in the south and east (McGlone, 
1989b; McFadgen, 2003a). European settlement, especially in the early years post AD 1844 saw large parts of open country cleared by hand for agriculture. As a result, vast areas of the landscape were convert to exotic pasture (Poaceae family), with plants such as sweet vernal grass (Anthoxanthum ordoratum), timothy (Phleum pratense), yorkshire fog (Holcus lanatus), cocksfoot (Dactylis glomerata) and couch (Poa spp.) introduced (Hill, 1963b). Rapid intensification periods from early to mid 1900s resulted in further deforestation of lowlands and eastern uplands pastures. A large majority of this consisted of Australian sheep burrs, Acaena ovina and Xanthium spinosum as well as the common thistle (Cnicus lanceolatus) and sheep sorrel (Rumex spp.)(Wardle, 1991). The land surrounding Lake Nganoke currently consists of agricultural pasture and a mix of exotic and native tall trees.

Typically, the Wairarapa is categorised as having cool wet winters and stable dry summers, with typically moderate to high winds experienced during spring and summer. Average temperatures range from $20-28^{\circ} \mathrm{C}$ in summer, keeping consistently below $10^{\circ} \mathrm{C}$ in winter (A.K. Booth, 1969; Hawke \& Summers, 2003). Annual rainfall varies from 800$1,200 \mathrm{~mm}$, with the rainfall more variable during the summer months and generally of higher intensity throughout winter (Guggenmos et al., 2011). Regionally, the western areas are wetter than the east due to orographic lift from the Rimutakas and Tararua ranges.

The Wairarapa is made up of many catchments, with headwaters in the low to mid altitude of Rimutakas, Tararua and Eastern Wairarapa hills. Generally speaking, these are all small river systems with high flows in winter and low flows in summer. Water is largely provided to these systems by rainfall and snowmelt, draining towards the coast. A small majority of these catchments are also supplied from underlying groundwater systems, subsurface and soil flows.

\subsection{SOUTHERN PLAINS}

The Southern Plains (which Lake Nganoke is located within) are characterised by lowlying flood plains, the Ruamahanga River, Lake Wairarapa and the Kahutara dunes. The area is bordered by Lake Onoke to the south, Lake Ferry road to the east, and SH53 to the north (Figure 4.2). The general land around Lake Wairarapa is periodically flooded. Originally permanently water-logged, this land once supported an extensive wetland; 
however this was significantly diminished after the Ruamahanga River diversion (1968) and the flood control barrage (1974) (Miskell, 2010).

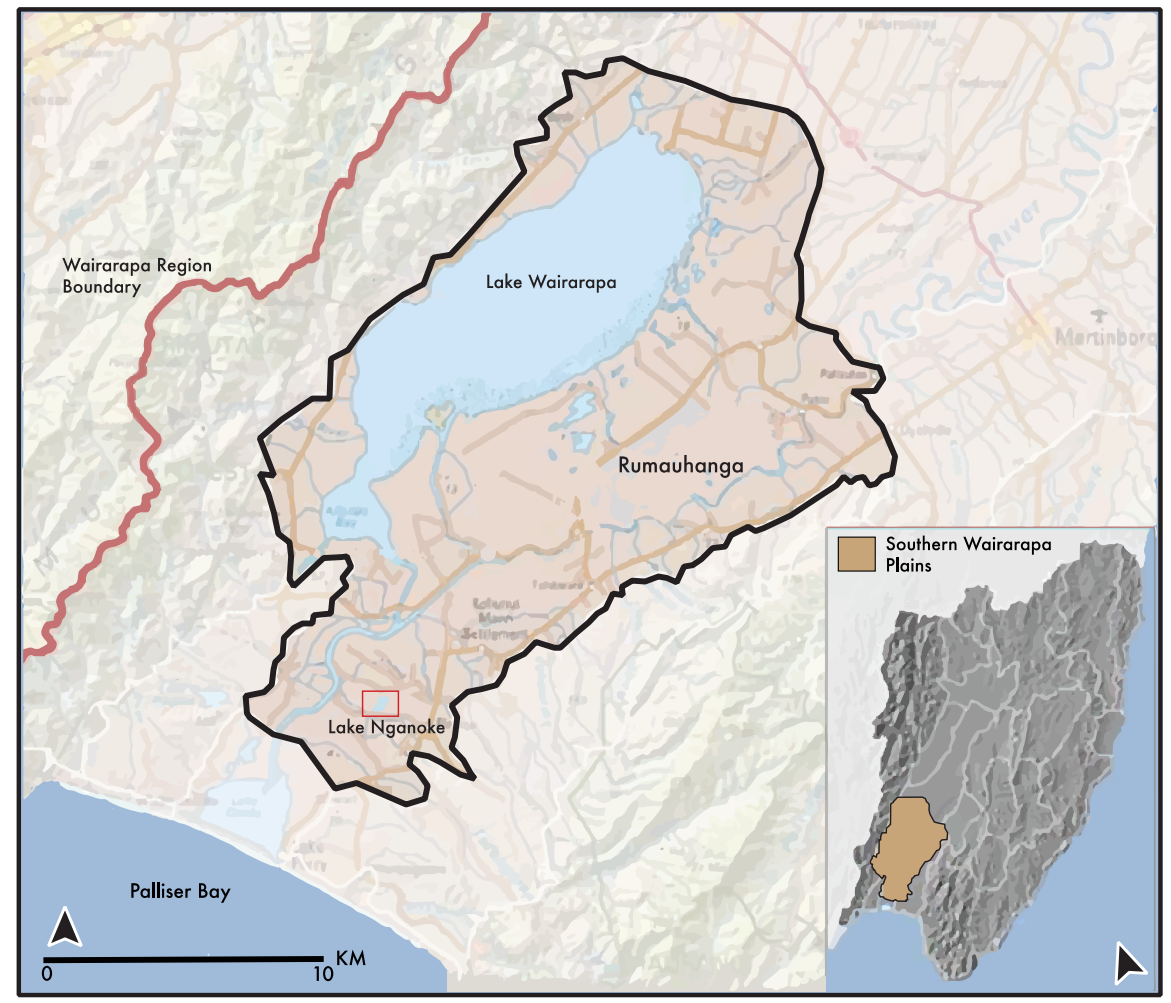

Figure 4.2: Location of the Southern Plains, New Zealand Adapted from Miskell (2010)

The surrounding area comprises fertile plains and river terraces. The predominant land type is classified as a plain, with the main landuse being horticulture, cropping and dairying. The soil type is fine grain silt, sand and gravel deposits which have likely travelled downstream, originating in the ranges. The prevalent land cover is pasture, with frequent plantings of poplar, dense plantings of willow and the scattered remnants of kahikatea and cabbage trees (Miskell, 2010). The land experiences moderate rainfall $(1000 \mathrm{~mL})$ and is dominated by sheep and beef farming and large-scale dairying. Typically, the Southern Plains have a low density of settlement and are extensively grazed by large farming systems (Miskell, 2010).

\subsection{HUMAN SETTLEMENT AND AGRICULTURAL DEVELOPMENT}

This section reviews evidence and past research concerning Polynesian and European settlement within the Wairarapa region. Specifically, four zones are defined in order to provide greater insight into findings within Chapter 6. While not directly indicative of settlement at a local scale, the following evidence is likely to be representative of Lake Nganoke's catchment. 
In the Wairarapa region, anthropogenic modifications likely began with moderate deforestation of the lowlands by Polynesian settlers. While it has been established that Polynesian settlement occurred within New Zealand c. 700-800 calibrated years before AD 1950 there is evidence that the settlement of Wairarapa may have not occurred until later ( AD 1350 - 95\% CI: AD 1280 - 1420)(Anderson, 1991; McFadgen, 2003b; McIntyre, 2012). Dates produced through radiocarbon techniques consist of a charcoal tree root buried beneath a garden at Okoropunga (eastern coast of the Wairarapa). Furthermore, paleo reconstruction of Lake Pounui (west of Lake Wairarapa) uses pollen records to further date Māori arrival inland, estimating a later period of AD 1500 to 1600 (Cochrane, 2017). Polynesian arrival within the Wairarapa is therefore defined as a range between the maximum radiocarbon dates (AD 1300) and minimum pollen stratigraphy (AD 1600) i.e. AD 1450 (95\% CI: 1156 - 1744); pre-human baselines are recognised as any date prior.

First European arrival within the Wairarapa (Palliser Bay) is estimated at $\sim$ AD 1770. Widespread settlement of the Wairarapa region did not commence until AD 1844 with the establishment of two of New Zealand's earliest sheep stations (A.K. Booth, 1969; Mair, 1972; Leach, 1981; Trodahl et al., 2016a). By 1854, Masterton, Carterton, Greytown and Featherston were all settled, (Hill, 1963a; Leach, 1981; Fallon, 2015). Cochrane (2017) further supports these findings, with pollen records indicating formal settlement of the Wairarapa valley in AD AD 1825 (95\% CI: 1789 - 2068). Largescale European settlement within the Wairarapa region is consequently accepted as 1850 which fits with historical evidence of formal settlement of the Wairarapa Valley in AD 1853 (Leach, 1981; Hill, 1963).

The fertility and ease of development for agriculture meant that the plains and lowlands were readily developed for agriculture and consequently extensively modified. In 1949, advancements in aerial topdressing saw the first arrangement for aerial fertilisation within NZ. A Wairarapa farmer, L.T Daniell, arranged for 127 tonnes of fertiliser (the first large operation within NZ) to be dropped on 11 properties (Wendelken, 1976). As a result, agriculture rapidly intensified with stocking rates lifted from 1-2 ewes per acre to a minimum of 3 (A.K. Booth, 1969). By AD 19692.75 million sheep and 50,000 milking cows were located within the Wairarapa. In current times, the Wairarapa is home to three million sheep, 230,000 dairy cattle and 257,000 beef cattle (Anastasiadis \& Kerr, 2013a). 
Agricultural intensification within Wairarapa is therefore defined by advancements in technology and dated AD 1950 to present.

Based on literature and historical accounts the timing of landuse zones within the Wairarapa are defined as:

Pre-human: pre 1450

Māori: 1450 to 1850

European: 1850 to 1950

Intensification: 1950 to present

These a priori zones will be used throughout the thesis and their validity for Lake Nganoke examined in the Sections 7.1.1, 7.2.1, 7.3.1 and 7.4.1.

\subsection{LAKE NGANOKE}

Lake Nganoke is a small shallow lake on private land located in the southern end of the Southern Plains $\left(41^{\circ} 21^{\prime} 20^{\prime \prime} \mathrm{S}, 175^{\circ} 11^{\prime} 10^{\prime \prime} \mathrm{E}\right)$ (Figure 4.3). It has a surface area of approximately $0.049 \mathrm{~km}^{2}$ and a depth of no more than $2 \mathrm{~m}$. The catchment of the lake largely consists of agricultural pasture used for farmland, covering approximately $1.5 \mathrm{~km}^{2}$ to the south east of the lake. Currently, the lake is surrounded by a compact $5 \mathrm{~m}$ riparian buffer zone on the northern, eastern and western side. This is somewhat diminished on the southern side, however the catchment located to the east of the lake is extensively planted, with riparian thickness minimum of $20 \mathrm{~m}$ in some parts. To date, limited water quality analysis has been measured from the lake, making it an ideal candidate for the paleo approach.

Dominant species surrounding the lake include: Cordyline australis, Phormium tenax, Carex secta, Typha orientalis, Cyperus ustulatus, Melicytus ramiflorus, Corynocarpus laevigatus, Pinus, radiata and Salix sp. (Department of Conservation, 2000).

The Turanganui Romney Stud is a fourth generational sheep and beef farm surrounding Lake Nganoke. Little is known of the land prior to the purchase on April $18^{\text {th }}, 1907$. Whilst the sale originally involved $6.84 \mathrm{~km}^{2}, 4 \mathrm{~km}^{2}$ was subdivided with a brother giving the Stud farm $2.84 \mathrm{~km}^{2}$ (Figure 4.3). 


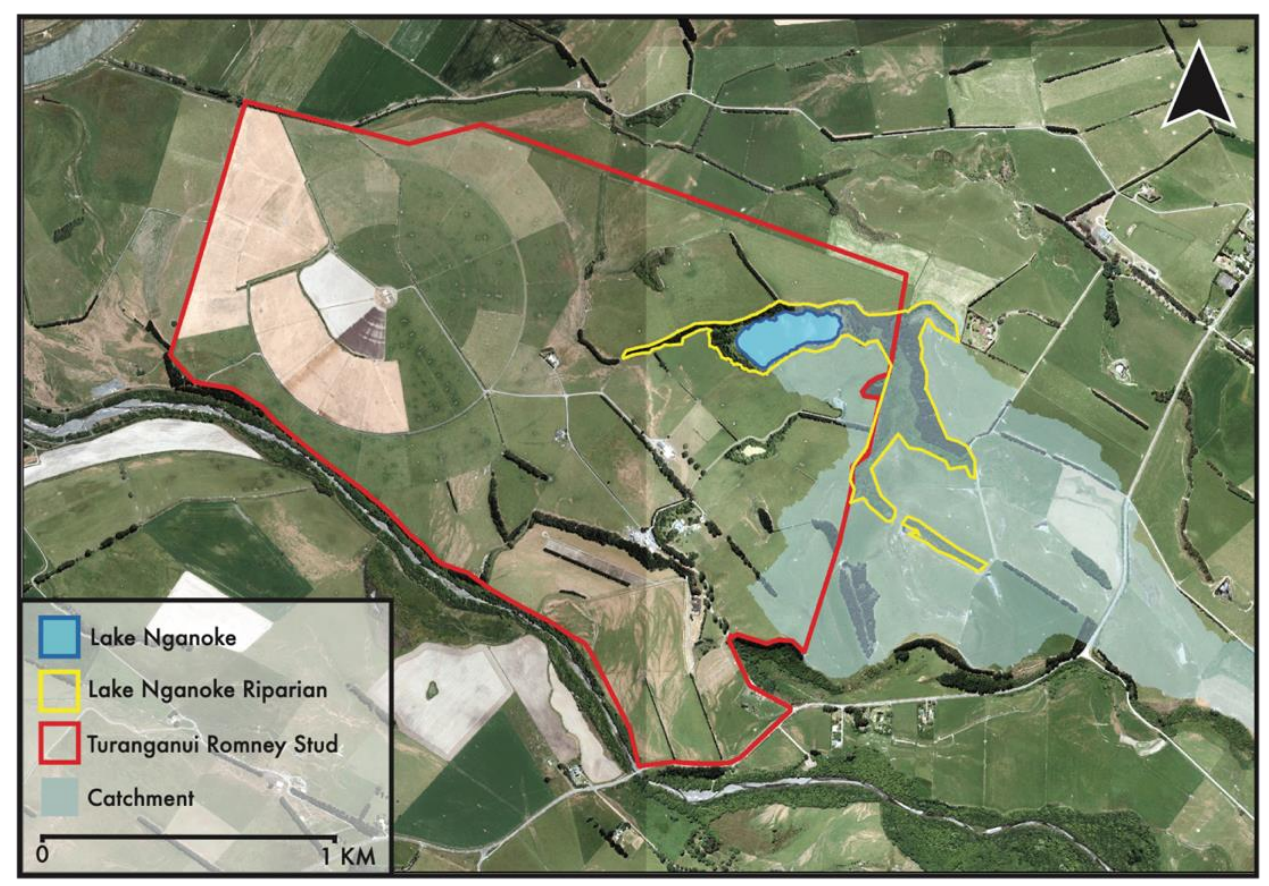

Figure 4.3: Lake Nganoke and surrounding land.

Displayed is Lake Nganoke (blue), the riparian zone (yellow), Turanganui Romney Stud (Red) and the catchment (grey). 


\section{CHAPTER 5: METHODOLOGY AND METHODS}

\subsection{METHODOLOGY}

Historical baselines can be used as the conceptual benchmark for lake ecosystem and water quality assessment and management (Battarbee, 1999; Duarte et al., 2009; Bennion et al., 2011). Furthermore, the assessment of landuse change prior to and after human arrival potentially provides a greater understanding of observed historical lake ecosystem and changes in water quality. Reconstructing the past environment of Lake Nganoke will therefore allow for the assessment of anthropogenic impact with respect to natural baseline conditions, producing information crucial to informing future mitigation strategies.

Paleolimnological methods are fast becoming recognised as an essential tool for evaluating past lake health internationally (Korsman \& Birks, 1996; Battarbee, 1999; Bennion \& Battarbee, 2007; Ruhland et al., 2008; Bennion et al., 2011), and nationally (Newnham, Lowe, \& Matthews, 1998; McGlone \& Wilmshurst, 1999d; Augustinus et al., 2006; Augustinus et al., 2012; Perry et al., 2012). This thesis will therefore make use of a multiproxy paleo-based approach to reconstructs the past environment of Lake Nganoke. The use of multiple proxies provides correlation of evidence concerning the history of landuse, water quality and ecosystem change. In this respect, the greater the consensus between a wide range of proxies, the stronger the argument.

To investigate research hypothesis one "Anthropogenic landuse intensification in Lake Nganoke's catchment has resulted in ecosystem change and a sequential stepwise decrease in water quality from a prehuman baseline, through Māori subsistence, European agricultural and intensification" indicators of ecological health, catchment disturbance and human arrival will be evaluated. Specifically, a high resolution chronology will be created through the use of key radiometric dating techniques: ${ }^{210} \mathrm{~Pb},{ }^{137} \mathrm{Cs}$, bomb spike ${ }^{14} \mathrm{C}$, conventional ${ }^{14} \mathrm{C}$ and bio stratigraphic age constraints. Past landuse reconstruction will be informed through environmental Digital Droplet Polymerase Chain Reaction, geochemical analysis and palynology. Previous lake ecosystem and water quality change will be characterised through the use of $16 \mathrm{~s}$ ribosomal Polymerase Chain Reaction, hyperspectral imaging and residual phosphorous fractionations.

Research hypothesis two "The planting of a riparian zone around the lake has buffered lake water quality against intensification of agriculture" will be investigated using 
indicators of water quality and lake ecosystem change through periods of identified growth and maturity of riparian planting. The timing of planting and growth to maturity will be constrained using historical aerial photographs and compared to measures of water quality and ecosystem change.

\subsection{CORE RETRIEVAL AND SUBSAMPLING}

\subsubsection{CORE RETRIEVAL}

Five sediment cores were retrieved from Lake Nganoke using a Uwitech gravity corer with a 2-m-long, 65-mm diameter polyvinyl chloride barrel (Figure 5.1) (UWITECH, 2019). The Uwitech corer was used because it is operated by hand, is easily transportable, and captures the upper $2 \mathrm{~m}$ of sediment within a lakebed, making it perfect for sampling relatively small and shallow lakes. Individual cores are cut to $\leq 1$-m subsections within the field for logistical reasons (handling, transport, splitter/scanner rails, etc.)

Cores were taken at the depocenter of the lake's basin (i.e. the southern end: $41^{\circ} 21 ' 21.6^{\prime \prime S}$, and $175^{\circ} 11^{\prime} 07.7^{\prime \prime} \mathrm{E}: \sim 2 \mathrm{~m}$ deep), as this should provide the most complete record (Figure 6). Lengths were collected in 2019 and are as follows:

- LC1U: $77 \mathrm{~cm}$

- LC2U: $84 \mathrm{c} \mathrm{m}$

- LC3U: $93 \mathrm{~cm}$

- LC4U: $89 \mathrm{~cm}$

- $\quad$ LC6U: $92 \mathrm{~cm}$

After collection the cores were chilled at $4{ }^{\circ} \mathrm{C}$ in complete darkness until subsampling. Important to note, while LC5U was collected, this core was archived and therefore will not be included within this study. 


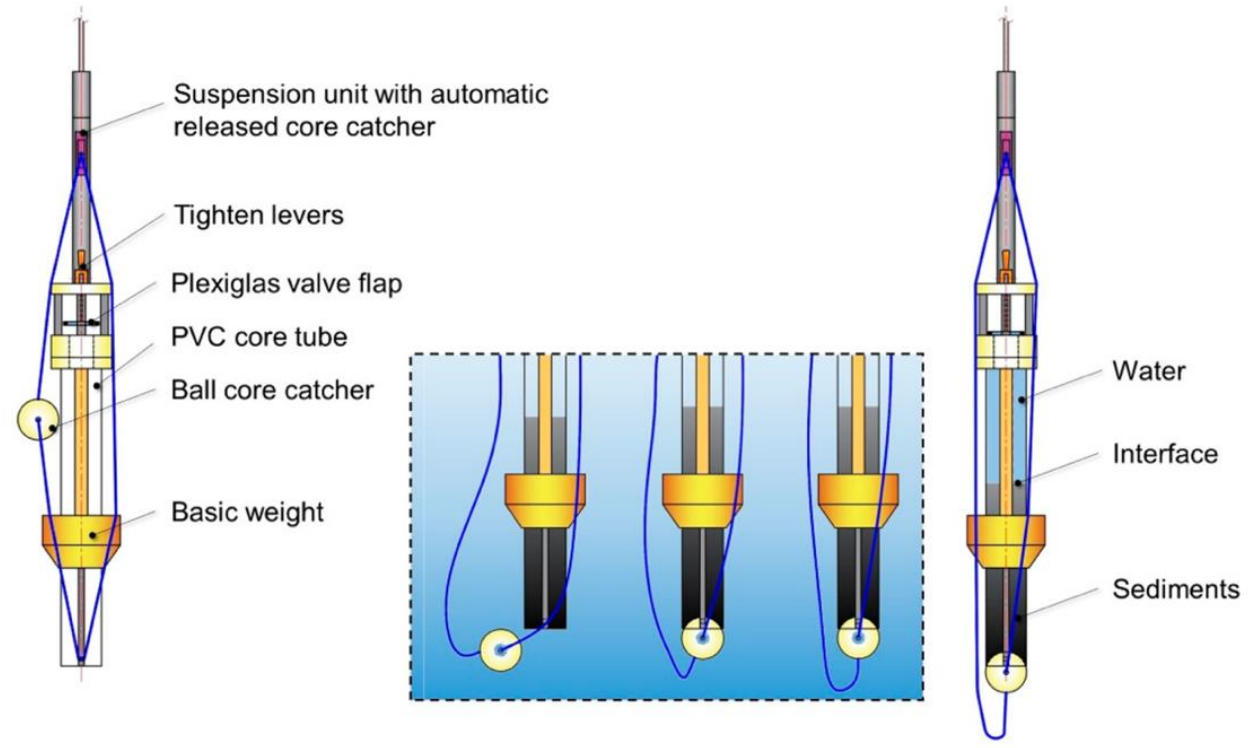

Figure 5.1: Structure and sealing sketch of the conventional UWITEC gravity corer. Retrieved from Gong et al. (2019)

\subsubsection{SUBSAMPLING}

All five cores were sliced along the longitudinal plane, with the top two to three millimetres of one half carefully removed with a sterile spatula. Stratigraphic units within the cores were determined using a combination of visual logging (colour, texture, structure and core deformation) and computed tomography (CT) scanning. In order to minimise the effects of oxidation on the core, visual logs were completed directly after core splitting, with photographs also taken for later reference. All five cores were run through a medical grade CT scanner at Pacific Radiology Boulcott Hospital. The raw data was imported and processed using the ImageJ software platform (Schneider et al., 2012). Hounsfield units were converted into $\mathrm{g} / \mathrm{cm}^{3}$ following the approach outlined in Reilly et al. (2017).

As the longest core, theoretically providing the greatest temporal extent, LC3U was selected as the master core to be sampled. However, due to the large amount of sediment required for the multiproxy approach, LC1U and LC6U were also sampled in order to complete the full range of proxy analyses. CT scans and hyperspectral scans were used to produce high resolution correlations between the sediment cores. Sample depths were transformed into master core depths using polynomial regressions developed using the inter-core correlations. 


\subsection{AGE-DEPTH MODEL}

\subsubsection{DATING}

The sampling resolution for ${ }^{14} \mathrm{C}$ and ${ }^{210} \mathrm{~Pb}$ was completed on $\mathrm{LC} 1 \mathrm{U}$ and comprised two approaches in order to gain both a precise and broader resolution of dating within the lake. The first included a targeted approach at $1-\mathrm{cm}$ intervals from $17-27 \mathrm{~cm}$ while the second broader approach included $2-\mathrm{cm}$ intervals from $8-16 \mathrm{~cm}$ and $5-\mathrm{cm}$ intervals from 28-84 cm. Macros used for dating were visually identified after core splitting or during proxy sub-sampling. Only three of the samples retained sufficient mass for dating after pre-treatment.

\section{Radiocarbon $\left({ }^{14} \mathrm{C}\right)$ dating}

Accelerator mass spectrometry (AMS) radiocarbon dating was carried out at the Rafter Radiocarbon Laboratory, GNS Science, on one seed capsule, and two leaf fragments collected from Lake Nganoke cores (Table 2). Once collected, samples were rinsed in a $90-\mu \mathrm{m}$ and $150-\mu \mathrm{m}$ sieve stack using distilled water, before being inspected under a microscope to identify the sample and remove contaminants. Samples were then placed in an ultrasonic bath to remove any remaining contaminants, dried in a $50^{\circ} \mathrm{C}$ oven overnight and weighed. Acid/alkali/acid pre-treatment, using $0.5 \mathrm{M} \mathrm{HCl}$ and $1.0 \mathrm{M}$ $\mathrm{NaOH}$, was carried out on plant material to isolate the humin fraction.

While sample pre-treatment, chemical treatment, graphitisation and measurement are the same for both conventional ${ }^{14} \mathrm{C}$ dating and bomb spike dating, calibration is not. Conventional ${ }^{14} \mathrm{C}$ dates were calibrated using the SHcal13 curve (Reimer et al., 2013), whereas bomb spike dates were calibrated with SH1-2 (Hua et al., 2013).

\section{Lead $^{210}$ and Caesium ${ }^{137}$}

Dating of ${ }^{210} \mathrm{~Pb}$ relies on the estimation of the residual radioactivity arising from the presence in the sediments of unsupported ${ }^{210} \mathrm{~Pb}$ derived from 'rain-out' onto the surface of the water body beneath which the sediments have accumulated (Appleby \& Oldfield, 1978b; Fitzpatrick et al., 2003).

The sampling strategy comprised two approaches in order to gain both a precise and coarser resolution of dating within the lake. The first included a targeted approach with the aim of definitively identifying the $1954 \mathrm{Caesium}^{137}\left(\mathrm{Cs}^{137}\right)$ horizon within the same samples as ${ }^{210} \mathrm{~Pb}$. The second takes a more complete approach capturing measurements 
throughout the core. Particular depths of interest were informed through a previous bomb spike date of 1958 and palynology giving a rough estimate of European settlement around 1840 (defined by the presence of Pinus).

Once samples were collected, radionuclide measurements were made using gamma spectrometry at the Institute of Environmental Science and Research (ESR), Christchurch, New Zealand. Activities were quantified using a gamma counter with a high-purity germanium well detector. Activities are reported in $\mathrm{Bq} \cdot \mathrm{kg}^{-1}$ and the uncertainties are based on the combined standard uncertainty (uc) multiplied by a coverage factor $(\mathrm{k})=2$ (providing a level confidence of $95 \%$ ) as described by WHO (1995). Core chronology from ${ }^{210} \mathrm{~Pb}$ were calculated using the constant rate of supply (CRS) model in R by means of the paleolimbot package (Dunnington, 2019). Assuming that the supply of unsupported ${ }^{210} \mathrm{~Pb}$ to the sediment is the same for each time interval, the CRS model is calculated as follows:

\section{Equation 1}

$$
t_{z}=\lambda^{-1}-1 \ln \left(A_{0} A_{z}^{-1}\right)
$$

Where $(\mathrm{t})$ is the age of any interval $(\mathrm{z}),(\lambda)$ is the ${ }^{210} \mathrm{~Pb}$ decay constant $\left(0.031\right.$ year $\left.{ }^{-1}\right),\left(\mathrm{A}_{0}\right)$ is the integrated activity from the surface and $\left(\mathrm{A}_{\mathrm{z}}\right)$ is the integrated activity to $\left(\mathrm{A}_{0}\right)$ (Appleby \& Oldfield, 1978b).

\subsubsection{AGE MODELS}

An age-depth model was constructed using the P Sequence prior model in OxCal 4.3 (Ramsey, 2000; Ramsey, 2008). The P Sequence prior treats sediment deposition as a Poisson process, where the prior permits accumulation of a sedimentary sequence to fluctuate around a constant rate (Vandergoes et al., 2018). The model was parametrised using a variable event thickness constant $(\mathrm{k})$, which is a loosely defined prior that ranges uniformly over two orders of magnitude above and below $1 \mathrm{~cm}^{-1}$ (Bronk Ramsey \& Lee, 2013).

\subsection{LANDUSE RECONSTRUCTION}

\subsubsection{PALYNOLOGY}

The pollen stratigraphy was used to identify changes in regional and local vegetation as well as fire histories through time (Section 5.4.2) Palynology sampling was completed prior to this thesis and consisted of 16 samples from LC3U. Pollen was provided by Xun 
Li (GNS), who followed an adapted preparation method outlined in Faegri et al. (1989). A relative pollen diagram was produced by normalising taxa counts by the dryland pollen sum, defined as the sum of pollen grains from tall trees, small trees \& shrubs and herbs. Fern spores and wetland taxa are not included but the percentage of fern spores and wetland taxa were calculated against the dryland pollen sum.

The main processing steps undertaken included: acid wash (remove calcium), acetolysis, heavy liquid flotation (remove mineral fraction), filtering through $6-\mu$ m nylon cloth meshes (remove fine materials), and slide mounting. Every sample weighed roughly 0.25 and $0.5 \mathrm{CC} \mathrm{ml}$. Minimum dryland pollen sum was approximately 150 grains but usually ranged between 150 and 200 grains. Charcoal particles were enumerated from pollen slides.

\subsubsection{CHARCOAL}

Charcoal analysis was also qunatified as part of the palynology sampling and presented alongside pollen data by Xun Li. Charcoal counts were converted to concentrations (charcoal particles $\mathrm{cm}^{-3}$ ) by dividing counts by volume of sediment sieved (Perry et al., 2012). Charcoal counts on pollen slides are used to reconstruct charcoal abundance, with microscopic equal to $<100 \mu \mathrm{m}$ and macroscopic $>100 \mu \mathrm{m}$.

\subsubsection{ANALYSIS OF ENVIRONMENTAL DNA USING DROPLET DIGITAL PCR}

The sampling strategy for environmental DNA comprised two approaches in order to gain both a detailed and broader understanding of environmental change within the lake. The first included a targeted approach on core LC3U at 1-cm intervals over three key areas of interest (pre-Polynesian settlement, European arrival/intensification and riparian planting). The second provided a more holistic approach at 2-, 3- and 5-cm intervals outside of these periods of interest. Particular areas of interest were identified through a combination of hyperspectral scanning, radiocarbon dating, palynology and historical reconstruction and included $12-25 \mathrm{~cm}, 38-42 \mathrm{~cm}$ and $57-72 \mathrm{~cm}$.

Droplet Polymerase Digital Chain Reaction (ddPCR) was used to quantify concentrations of bacteria associated with ruminants within the samples in order to provide a proxy for changes in stocking rates in Lake Nganoke. This was completed Cawthron Institute in Nelson. 
All steps of the molecular analysis (DNA extraction, Polymerase Chain Reaction (PCR) or ddPCR) were conducted in a separate sterile laboratory, with chronological workflow to ensure no cross contamination. Ultra-violet sterilisation was available in all rooms dedicated to DNA extraction, amplification set up and template addition, and was used for a minimum of $15 \mathrm{~min}$ before and after each use. The ddPCR set-up and template addition were undertaken in laminar flow cabinets with high-efficiency particulate air filtration. Aerosol barrier tips (Eppendorf, 2019) were used throughout to avoid contamination between samples.

Sediment sub-samples were kept frozen $\left(-20^{\circ} \mathrm{C}\right)$ and in the dark until DNA extraction. Operating in a laminar flow hood, approximately $0.25 \mathrm{~g}$ of sediment from each sample was weighed into the first tube of a DNEasy® PowerSoil@ Soil DNA Isolation Kit (Qiagen, 2019). DNA was then extracted with DNA eluted in $100 \mu \mathrm{L}$. Extraction of DNA was performed in batches of twelve including a negative control every second batch. This negative control contained all reagents but no sediment, providing a means of assessing whether contamination had occurred. Following extraction, DNA concentrations were measured with the DNA protein ratio estimated for each sample using a Bio Spectrophotometer (Eppendorf, 2019). Samples were stored in the freezer $\left(-20^{\circ} \mathrm{C}\right)$ until further analysis.

\section{Droplet digital PCR amplification}

Absolute concentrations of a 16S rRNA gene specific to ruminants was measured in all samples using a BioRad QX200 Droplet Digital PCR system and Bacteroides Ruminant specific primers and a probe (BacR_f'-GCGTATCCAACCTTCCCG', BacR_r'CATCCCCATCCGTTACCG', BacR_p'-FAM-CTTCCGAAAGGGAGATTMGBNFQ', (Reischer et al., 2006). Each ddPCR reaction included $450 \mathrm{nM}$ of each primer and probe, $10 \mu \mathrm{L}$ of $1 \times$ BioRad ddPCR Supermix for probes, $1 \mu \mathrm{L}$ of DNA, and sterile water for a total reaction volume of $22 \mu \mathrm{L}$. The BioRad QX200 droplet generator divided all reaction mixtures into nanodroplets by mixing $20 \mu \mathrm{L}$ of the reaction mixture with $70 \mu \mathrm{L}$ of BioRad droplet oil. Following processing, a total nanodroplet volume of $40 \mu \mathrm{L}$ was transferred to a PCR plate for amplification. The following cycling protocol (40 cycles of $94^{\circ} \mathrm{C}$ for $30 \mathrm{~s}, 60^{\circ} \mathrm{C}$ for $60 \mathrm{~s}$ ) was used and then analysed on the QX200 instrument held at $95^{\circ} \mathrm{C}$ for $10 \mathrm{~min}$, with a final enzyme deactivation step at $98^{\circ} \mathrm{C}$ for 10 $\min$. 
For each ddPCR plate run, at least one negative control and one positive control were included. When inhibition was observed or samples were too concentrated these were diluted with RNA/DNA-free water (ThermoFisher, 2019) and reanalysed. The results where then converted to copies $\mathrm{g}^{-1}$ using the following formula:

\section{Equation 2}

$e D N A$ sediment samples $=\frac{(\text { Number of copies per } \mu L \times 22 \mu L \times 100 \mu L)}{(\text { weight of lyphophilized starting material }(\text { in } g))}$

\subsubsection{GEO-CHEMICAL ANALYSIS - CADMIUM, TOTAL NITROGEN AND TOTAL CARBON}

A two-tiered sampling resolution was undertaken in the sampling of LC6U for both geochemical analysis and $\mathrm{P}$ fractionation. Funding constraints and sediment volumes dictated a maximum of 15 samples. A 2-cm sampling resolution was used over the transition between the European and Intensification period (samples at 8, 12, 16, 20, 22, and $24 \mathrm{~cm}$ ). Coarser resolution was used over the remaining core with an emphasis on identifying periods of landuse change (samples at 28, 34, 40, 50, 60, $70 \mathrm{~cm}$ ).

Chemical analysis of cadmium was conducted as part of the $\mathrm{P}$ fractionation method at Analytica Hamilton. Sample extracts were diluted and analysed on a Perkin Elmer 300D ICP-MS using collision mode (KED) for all elements and scandium as the internal standard. Detection limits $\left(\mathrm{mg} \mathrm{L}^{-1}\right)$ for the machine are $\mathrm{Cd}<0.02$ and $\mathrm{Pb}<0.04$.

Chemical analysis of total nitrogen and carbon was carried out on 15 samples as part of the $\mathrm{P}$ fractionation method at Analytica, Hamilton. The reporting limit was $0.02 \mathrm{~g} / 100 \mathrm{~g}$ dry weight and $0.1 \mathrm{~g} / 100 \mathrm{~g}$ dry weight for total nitrogen and total carbon, respectively. Specifically, samples were air-dried and sieved to $<2 \mathrm{~mm}$ then analysed by dumas combustion analysis with infrared detection, based on ISO 10694:1995, IDT. Total organic carbon is measured after first removing carbonates by hydrochloric acid treatment of the air dried sample. Samples were prepared and analysed at Analytica Laboratories. $\mathrm{C}: \mathrm{N}$ ratios were calculated to infer the source of organic matter accumulating in the sediment. 


\subsubsection{AERIAL PHOTOGRAPHY}

Historical aerial photographs were sourced under 'The Local Government Geospatial Alliance' and used to establish and monitor the growth of Lake Nganoke's riparian zone (LGGA, 2019). Using the software ArcGIS Pro, photographs were geo-referenced and annotated, with changes in Lake Nganoke and riparian growth outlined.

\subsection{LAKE ECOSYSTEM AND WATER QUALITY RECONSTRUCTION}

\subsubsection{HYPERSPECTRAL IMAGING}

Hyperspectral imaging was used to derive the Relative absorption band depth (RABD) at 660-670 $\mathrm{nm}$ as a proxy for Chlorophyll a and in-lake productivity. All three cores LC1U, LC3U and LC6U were scanned. Cores were prepared by scraping the surface sediment ensuring a smooth and flat surface. This guaranteed there were no pockets or deviations within the surface, as these can create false readings within the hyperspectral data. Hyperspectral imaging scans were then collected for each of the four sediment cores using a Specim SISU single core scanner with a sCMOS-50-V10E spectral camera. Image preprocessing and normalization followed protocols from Butz et al. (2017). Spatial resolution was set to $1 \mathrm{~mm} /$ pixel at a spectral resolution of $660-670 \mathrm{~nm}$. Spectral indices were calculated in $\mathrm{R}$ version 3.4.0, with the RABD ratio $\mathrm{R} 670 / \mathrm{R} 680$ providing a simple estimate of changes of in-lake productivity downcore.

\subsubsection{BACTERIAL METABARCODING (16S rRNA)}

Bacterial metabarcoding targeting the 16S rRNA gene was undertaken on 42 samples. The sampling resolution is the same as that identified in Section 5.4.3.

\section{Amplification, sequencing and bioinformatics}

The V3-V4 region of the bacterial 16S rRNA gene was amplified by Polymerase Chain Reaction (PCR), using the bacterial-specific primers 341F: 5'-CCT ACG GGN GGC WGC AG-3' and 805R: 5'-GAC TAC HVG GGT ATC TAA TCC-3 (Herlemann et al., 2011; Klindworth et al., 2013). All batches included a negative and positive control. PCRs (48 $\mu \mathrm{L}$ ) containing $47 \mu \mathrm{L}$ of reagents and $1 \mu \mathrm{L}$ of extracted sediment DNA were amplified, with the reagent mix for one tube containing; $25 \mu \mathrm{L}$ of AmpliTaq Gold® 360 Master Mix (Technologies, 2019), $10 \mu \mathrm{L}$ of DNA/RNA free water (Technologies, 2019), $5 \mu \mathrm{L}$ of $360 \mathrm{GC}$ enhancer (Technologies, 2019), $5 \mu \mathrm{l}$ of BSA (Sigma) and $1 \mu \mathrm{L}$ of each primer at $10 \mu \mathrm{M}$. The cycling profile was; denaturation at $95^{\circ} \mathrm{C}$ for $10 \mathrm{~min}$, followed by 
35 cycles at $95^{\circ} \mathrm{C}$ for $30 \mathrm{~s}$, annealing at $52^{\circ} \mathrm{C}$ for $30 \mathrm{~s}$, extension at $72^{\circ} \mathrm{C}$ for $1 \mathrm{~min}$ and a final extension step at $72{ }^{\circ} \mathrm{C}$ for $7 \mathrm{~min}$.

Final products, including all negative extraction and PCR controls were visualized on a $1.5 \%$ agarose gel electrophoresis stained with Red Safe DNA Loading Dye (WORLD, 2019). UV illumination of the product also guaranteed amplifications of a single $400 \mathrm{bp}$ product. Purification and quantification of amplicons were performed with the 96-well SequalPrep ${ }^{\mathrm{TM}}$ Normalization Plate Kit (Harris et al., 2010), normalizing DNA concentrations up to $1.25 \mathrm{ng} \mu \mathrm{L}^{-1}$ per sample. Libraries were sent to New Zealand Genomics Limited at the University of Auckland for sequencing and paired-end sequences $(2 \times 250)$ generated on a MiSeq instrument using the TruSeqTM SBS kit (Illumina, 2019).

Sequence data were automatically demultiplexed using MiSeq Reporter (v2), and forward and reverse reads were assigned to samples. General sequence quality was assessed with FastQC, unwanted sequences were removed with Cutadapt. The DADA2 package (R / R Studio) was used to quality filter the sequences and remove sequences of poor quality. Amplicons were pooled into a single library and paired-end sequences $(2 \times 250)$ were generated on a MiSeq instrument using the TruSeq ${ }^{\mathrm{TM}}$ SBS kit (Illumina, 2019).

Due to time constraints, the bioinformatics were completed by John Pearman at Cawthron Institute. The R software version 3.4.2 (Team, 2017), RStudio software version 1.1.442 Studio (2019), and the phyloseq package (McMurdie \& Holmes, 2013) were used for merging data from all sequencing runs, normalising the samples at the same sequencing depth, and carrying out statistical analyses and plots design. Based on the rarefaction curves, samples were rarefied at 14800 reads through random subsampling with no replacement.

\subsubsection{STATISTICAL TESTING - NONMETRIC MULTIDIMENSIONAL SCALING}

In order to provide greater insight into the composition change of taxa within Lake Nganoke, a nonmetric multidimensional scaling (NMDS) based on Bray-Curtis distance was used to summarize the pattern of species occurrence between zones identified in Section 4.3 (Legendre \& Legendre, 2012). In order to test for statistical differences between these zones, an Adonis function of the $\mathrm{R}$ vegan package was applied, with values 
of $\mathrm{p}$ less than 0.05 indicating a significant difference between the taxonomic composition of the zones (Oksanen et al., 2013).

\subsubsection{PHOSPHOROUS FRACTIONATION}

This thesis pioneers the innovative approach of applying the phosphorous fractionation downcore. The sampling strategy is the same as that already identified in Section 5.4.4. In order to calculate the residual value, a complex process and assessment of all the $\mathrm{P}$ fractions must be completed. The methods used within this thesis, as described below, are based on Waters (2016).

\section{Pore water}

Prior to analysis, pore water was immediately separated from the sediment by centrifuging at $4000 \mathrm{rpm}$ for $40 \mathrm{~min}$, filtered through $0.45-\mu \mathrm{m}$ Millipore membrane and frozen until analysis. The remaining sediment was freeze-dried at $-18{ }^{\circ} \mathrm{Cfor} 48 \mathrm{hr}$ using the CHRIST Freeze Dryer (Fissore et al., 2018). Pore water samples were analysed for dissolved phosphorous by inductively coupled plasma optical emission spectrometry (ICP-OES). The limit of detection for $\mathrm{P}$ on this instrument is $0.00455 \mathrm{mg} / \mathrm{L}^{-1}$.

\section{$\underline{\text { Sequential chemical extractions }}$}

Extraction of phosphorous is based on Psenner et al. (1988) and adapted slightly from that described in Rydin (2000) (Figure 5.2).

The $\mathrm{P}$ forms targeted by the extraction steps are as follows;

1. $\underline{N H}_{4} \underline{C l-P} ;$

For each sample approximately $0.5 \mathrm{~g}$ of sediment were placed into a Falcon tube, weighed and recorded. $25 \mathrm{~mL}$ of $\mathrm{NH}_{4} \mathrm{Cl}$ solution was pipetted into the sample, weighed and placed on the shaker for $2 \mathrm{hr}$. Once thoroughly mixed, samples were centrifuged at $3900 \mathrm{rpm}$ for $15 \mathrm{~min}$ before filtering $(0.45 \mu \mathrm{m})$ to waste, keeping the remaining filtered sample plus sediment. The extracts were sent to Analytica for dissolved reactive phosphorous (DRP) analysis.

2. $\underline{B D-P ;}$

The $\mathrm{BD}$ step (involving bicarbonate/dithionite $\left(\mathrm{NaHCO}_{3} / \mathrm{Na}_{2} \mathrm{~S}_{2} \mathrm{O}_{4}\right)$ ) is a reducing reaction. $25 \mathrm{~mL}$ of $\mathrm{BD}$ solution was pipetted into solution, weighed and placed on the shaker for $1 \mathrm{hr}$. Samples were then centrifuged, decanted and 
filtered (as in step 1), with the extracts sent to Cawthron for analysis using an inductively coupled plasma mass spectrometer (ICP-MS).

\section{NaOH-tot-P;}

The $\mathrm{NaOH}$-reactive $\mathrm{P}(\mathrm{rP})$ step extracts remaining $\mathrm{P}$ forms which are sensitive to $\mathrm{pH}$ change. $25 \mathrm{~mL}$ of $0.1 \mathrm{~mL} \mathrm{NaOH}$ was pipetted into the sediment and weighed, before being placed on the shaker for $16 \mathrm{hr}$. The sample was then centrifuged, decanted and filtered (as in step 1) with the extracts sent to Cawthron for ICP-MS analysis.

$\mathrm{NaOH}-\mathrm{rp}$

$1 \mathrm{~mL}$ of $0.1 \mathrm{mLNaOH}$ was extracted from the sample and placed within a $50-\mathrm{mL}$ tube. The sample was then topped up with Milli-Q and weighed before being sent to Analytica for DRP analysis.

\section{4. $\underline{\mathrm{HCl}-\mathrm{P} \text {; }}$}

The $\mathrm{HCl}$ step targets remaining $\mathrm{P}$ forms, which are mobile at low $\mathrm{pH} .25 \mathrm{~mL}$ of $\mathrm{HCl}$ concentrate were pipetted into the remaining sediment from Step 3 and weighed, before being placed on a shaker for $16 \mathrm{hr}$. The sample was then centrifuged, decanted and filtered (as in step 1) with the extracts sent to Cawthron for ICP-MS analysis.

5. $\underline{\text { Res-P; }}$

Residual $\mathrm{P}$ is extracted with a strong acid digestion $\left(\mathrm{HNO}_{3}\right)$ and is considered to include refractory organic and inert inorganic forms. The residual sediment was sent to Analytical Labs for Total Recoverable P analysis.

6. Total

Total sediment $\mathrm{P}$ is considered to be the sum of the extracted $\mathrm{P}$ forms (SOE). 


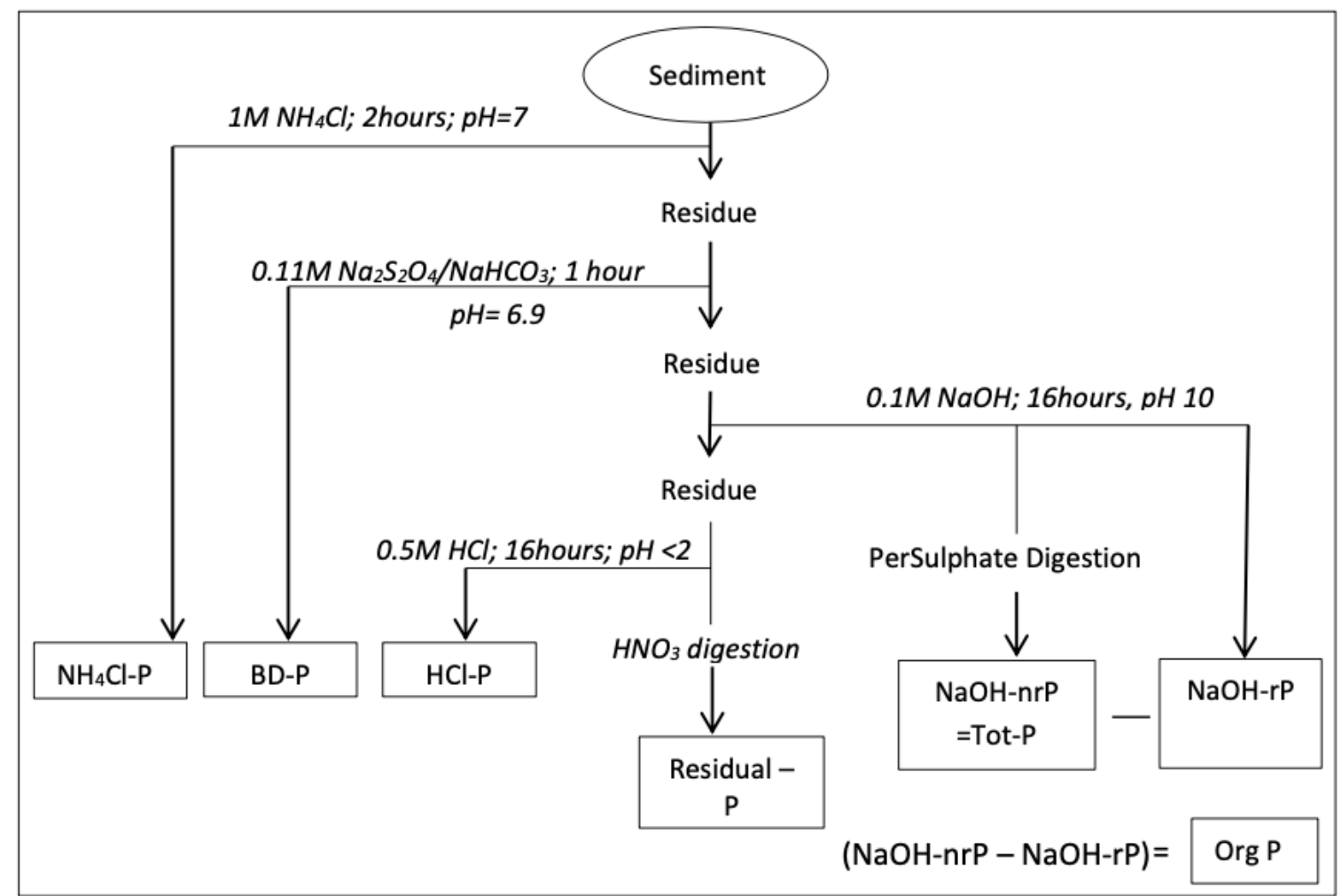

Figure 5.2: Sequential extraction scheme used on Lake Nganoke sediments.

Waters (2016)

\subsubsection{LOSS ON IGNITION (LOI)}

LOI sampling was completed as part of the geochemical analysis and $\mathrm{P}$ fractionation outlined in Section 5.4.4. Wet weight to dry weight (DW) ratios give an estimation of water content in the sediment and were determined by drying a sediment sample at $105^{\circ} \mathrm{C}$ for $24 \mathrm{hr}$. The sample was weighed prior to and after the drying process. These samples were then combusted at $550^{\circ} \mathrm{C}$ for $4 \mathrm{hr}$. The weight lost during ignition (LOI) gives a percentage of organic material by the following equations:

\section{Equation 3}

$$
L O I_{550=} \frac{\left(D W_{105}-D W_{550}\right)}{D W_{105}} \times 100
$$

Further ignition at $950^{\circ} \mathrm{C}$ for $2 \mathrm{hr}$ gives an estimate of carbonate in the sediment and was calculated with the following equation:

\section{Equation 4}

$$
L O I_{950}=\frac{D W_{550}-D W_{950}}{D W_{105}} \times 100
$$


The weight of carbonate in the original sample is the weight lost due to ignition at $950^{\circ} \mathrm{C}$ (Heiri et al., 2001). 


\section{CHAPTER 6: RESULTS}

Chapter 6 describes the results of proxy analyses that inform changes in landuse, lake ecosystem and water quality within Lake Nganoke and its surrounding catchment. This chapter begins by characterising the sedimentology and producing a chronology of four cores (LC1U, LC2U, LC3U, LC6U) from Lake Nganoke (Section 6.1).The results for landuse change proxies, including palynology, ruminant ddPCR, geo-chemical analysis, historical photography, and stocking/ fertilisation rates are described in Section 6.2. Measures of lake ecosystem and water quality change are described through the proxies, bacteria metabarcoding, hyperspectral imaging, phosphorous fractions and geochemical analyses (Section 6.3). All proxies described are classified into Pre-human, Māori, European and intensification zones; the timing of which are defined based on historic and previously published records germane to Lake Nganoke (see Chapter 2, Section 4.3). Finally, aerial photography of riparian establishment and growth are characterised and described. Figures within Sections 6.2 and 6.3 plotted against depth are displayed within appendix B.

\subsection{STRATIGRAPHY AND CHRONOLOGY}

\subsubsection{STRATIGRAPHY}

Defined on the basis of colour, texture, structure, organic content and CT scanning, cores LC1U, LC2U, LC3U and LC6U are characterised by five lithofacies that can be correlated accurately across all four cores. The exception is unit 5 , which is not observed in LC6U (Figure 6.1). Unit 1 is a dark brown (10YR3/2) silt that has massive structure and an LOI average (proxy for organic content) of 20.4\% 1 Sigma $+/-1.06 \%$. Similarly, unit 2 is an orange brown (2.5Y4/1) silt that has massive structure and an LOI average of $18.4 \% 1$ Sigma $+/-1.2 \%$. Consisting of a laminated-layer structure with sharp contacts, unit 3 is a mixture of dark, orange and pale brown colouring $(2.5 \mathrm{Y} 5 / 2,2.5 \mathrm{Y} 4 / 1,10 \mathrm{YR} 3 / 2)$ with an average LOI of $16.8 \% 1$ Sigma $+/-0.9 \%$. While unit 4 is an olive brown (2.5Y/1) silt with a massive structure, unit 5 is a greyish brown (N5, N4 and N7) silt with a laminated structure. No loss-on-ignition samples were available for either unit. The five lithofacies are easily distinguished in CT densitometry, with clear laminations found within units 3 and 5. Macrofossil samples for dating were taken from LC2U at depths of 12 and $60.5 \mathrm{~cm}$ and LC3U at depths of 13, 20.5, 26, 46, 57.5 and $83 \mathrm{~cm}$. 


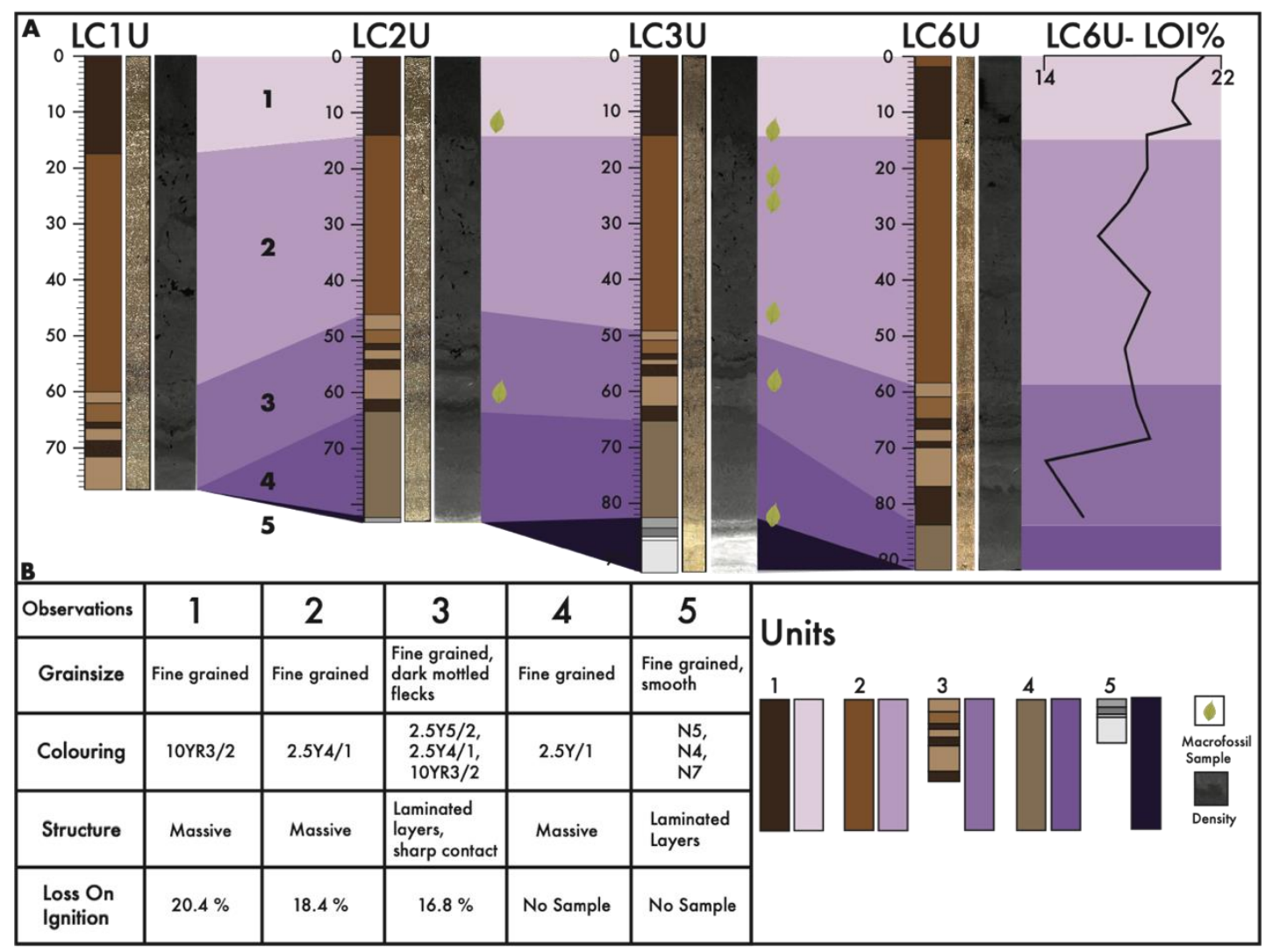

Figure 6.1: Stratigraphic characterisation (A) and observations (B) of cores LC1U, LC2U, LC3U and LC6U.

Cores are characterised from visual logs, scanned imaging and internal structures (CT). Lithofacies are described by colouring and grouped into five distinct units, with each of the five units characterised by grainsize, colouring, structure and averages of loss on ignition. Measurements of LOI\% are representative of LC6U only and averaged for units 1, 2 and 3.

\subsubsection{CORE CORRELATIONS TO MASTER STRATIGRAPHY}

Ten tie points were identified in each core (LC1U, LC2U, LC3U and LC6U) from hyperspectral imaging (RABD 660-670 nm) in order to correlate all data to a master stratigraphy (Figure 6.2). 


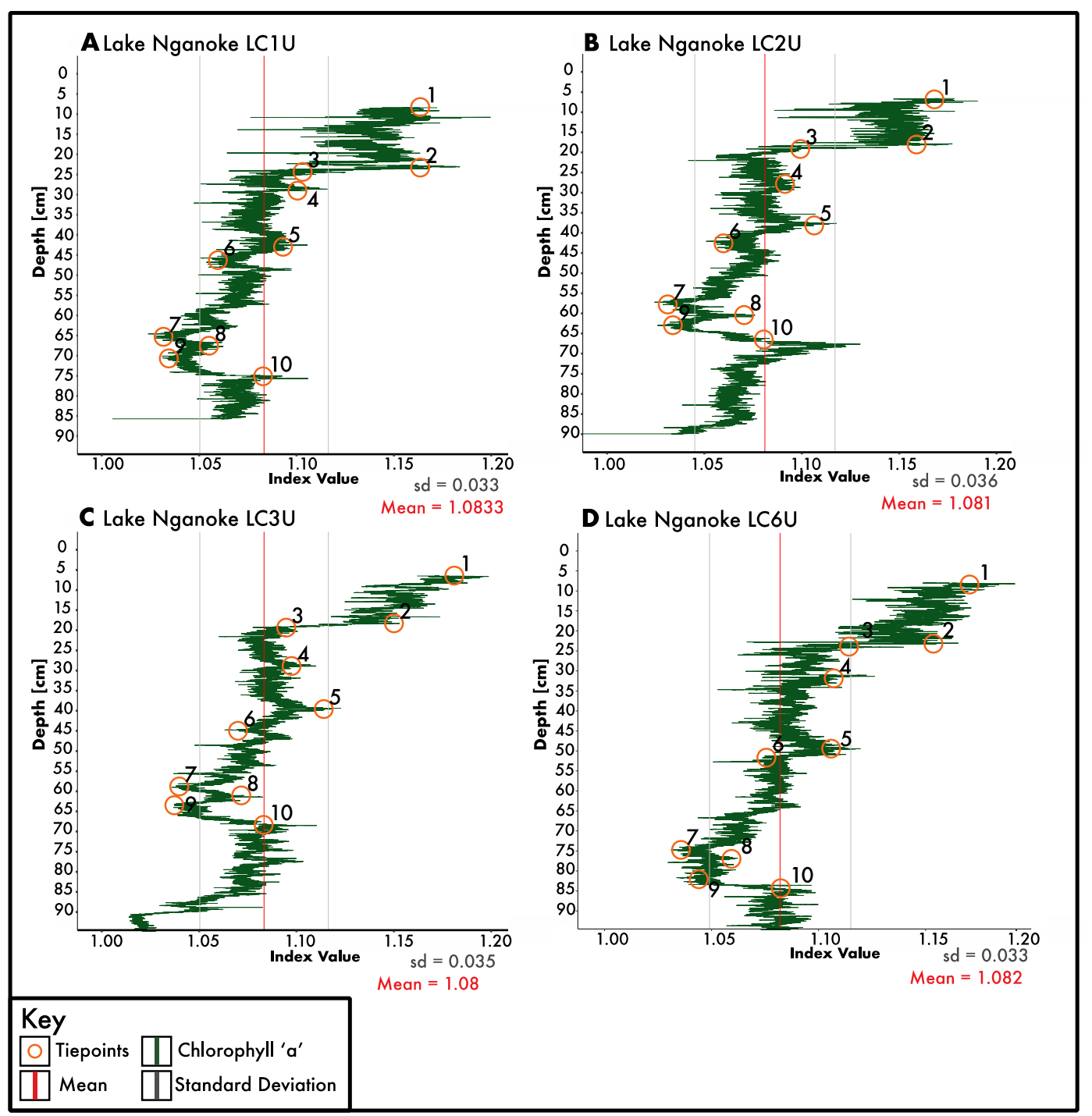

Figure 6.2: Correlations of cores LC1U (A), LC2U (B), LC3U (C) and LC6U (D).

Where correlated points are depicted in orange, with Chlorophyll an abundance (RABD at 660-670 $\mathrm{nm}$ ) in green, mean in red and standard deviation in grey. All points are defined by a clear change in Chlorophyll a throughout all four cores.

A master stratigraphy was created by regressing LC1U, LC2U and LC6U against LC3U using points identified in Figure 6.2. This resulted in the following polynomial regression curves (Figure 6.3):

\section{Equation 5}

$$
L C 3 U=-2.9525+(1.0006 \times L C 1 U)-\left(-0.0007 \times L C 1 U^{2}\right)
$$

$r^{2}=0.9981$

\section{Equation 6}

$$
L C 3 U=-0.3752+(1.0649 \times L C 2 U)-\left(-0.0007 \times L C 2 U^{2}\right)
$$

$\mathrm{r}^{2}=0.9995$ 


\section{Equation 7}

$L C 3 U=-0.6963+(0.8748 \times L C 6 U)-\left(-0.0001 \times L C 6 U^{2}\right)$

$r^{2}=0.9948$
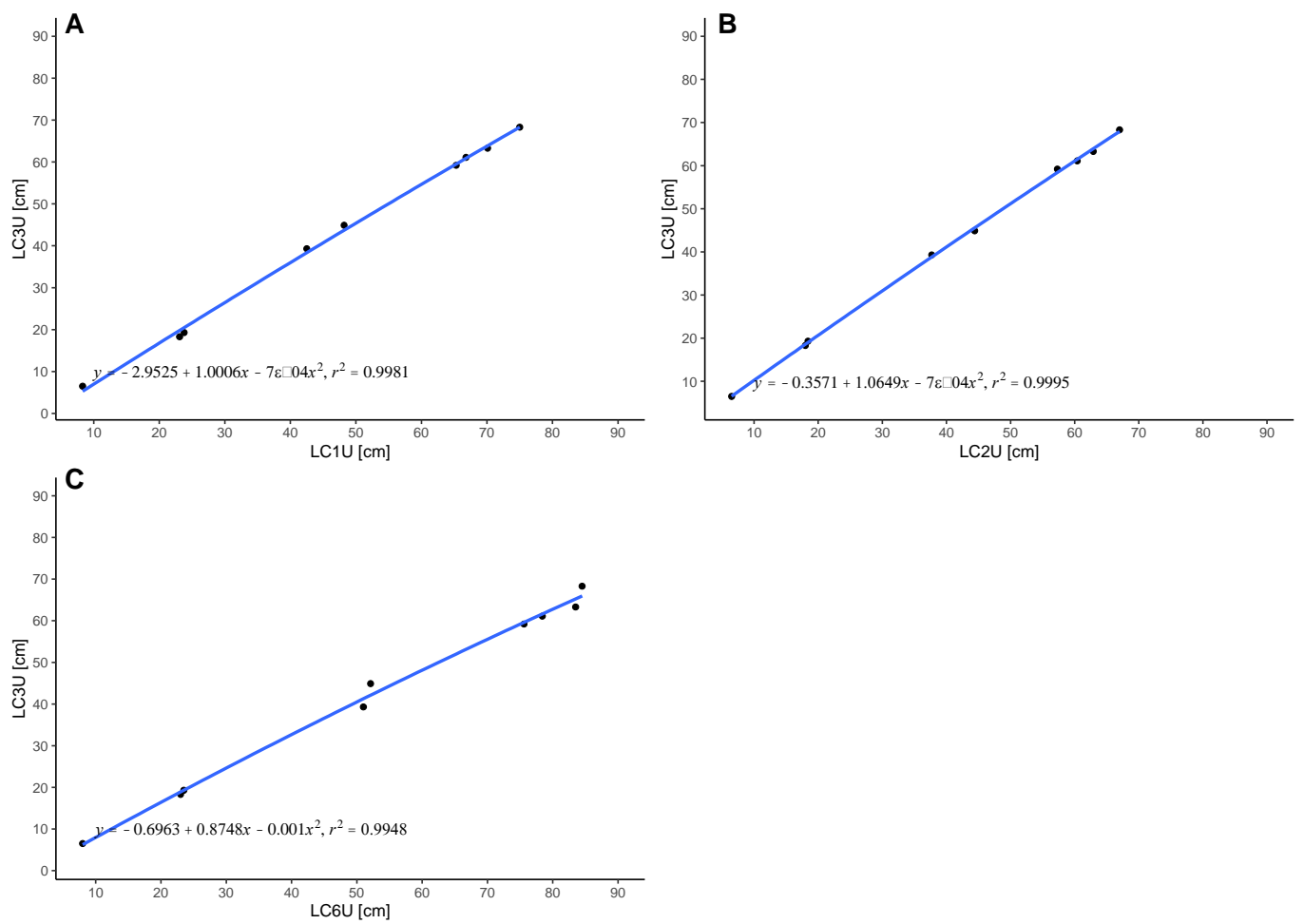

Figure 6.3: Polynomial regressions of cores LC1U (A), LC2U (B) and LC6U (C)

Correlations (blue) are calculated by regressing depths (black dots) on one core against the master core (LC3U). Error is displayed as grey

\subsubsection{AGE DEPTH MODEL}

Sediment within Lake Nganoke was dated using ${ }^{210} \mathrm{~Pb}$, bomb spike radiocarbon, biostratigraphy (pollen) and conventional ${ }^{14} \mathrm{C}$ techniques (See appendix A). Fourteen ${ }^{210} \mathrm{~Pb}$ samples were collected from Lake Nganoke, ranging from 0 to $66 \mathrm{~cm}$ (LC3U correlated depth) (Figure 6.4A). The CRS model returned a total of nine dates, ranging from AD 2019 (95\% Confidence Interval (CI): AD 2032 - 2005) to AD 1934 (95\% CI: AD 1951 - 1917) (Figure 6.4B). Bomb spike dates returned fraction modern values of 1.063314885 (+/-0.00277113) (95.4\% AD 1958) and 1.043163663 (+/-0.002498979) (90\% AD 1957). Bio-stratigraphic ages were based on known taxa arrival dates within literature, and as such, detections of willow at $38.5 \mathrm{~cm}$ were dated to AD 1870 (95\% CI 1850 - 1889) pine at 51.5cm to AD 1865 (95\% CI 1829 - 1904) and Māori arrival based on bracken fern at $58.5 \mathrm{~cm}$ to $\sim \mathrm{AD} 1450$ (95\% CI 1255 - 1645). The radiocarbon sample from $62.8 \mathrm{~cm}$ depth provided a calendar age once calibrated of AD 1431 (95\% CI AD 1415 - 1446). 

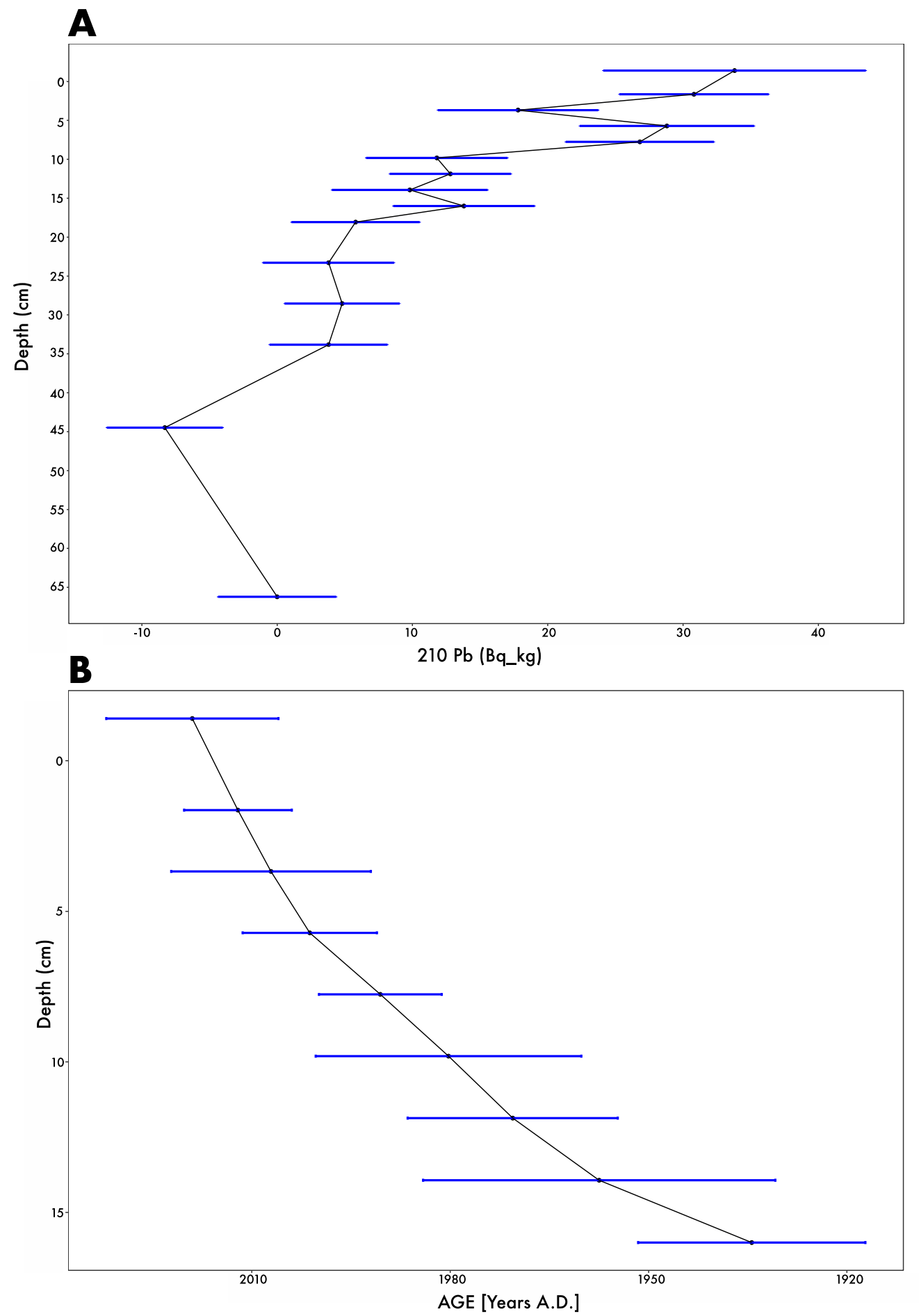

Figure 6.4: ${ }^{210} \mathrm{~Pb}$ excess plotted against depths (A) and ages calculated using the CRS model (B).

Where 95\% uncertainties are depicted in blue.

Figure 6.5 depicts the age-depth model for Lake Nganoke produced using the $\mathrm{P}$ sequence prior and independent age information described above. The model covers a range from AD 1150 (95\% CI: AD 759 - 1366) to AD 2019 (95\% CI: AD 2018 - 2019) with maximum precision located at depth $0 \mathrm{~cm}$ and minimum at $93 \mathrm{~cm}$. The agreement index provides a measure of model fit to the chronological data and is the degree to which the 48 
posterior probability density functions (PDFs) overlaps with the likelihood PDFs. Good model fit is defined as a model agreement index greater than 60\% (Bronk Ramsey, 2008). The agreement index for Lake Nganoke is $132 \%$, demonstrating the robustness of the age model. The model also demonstrates that sedimentation rates have not been constant over the 1-kyr duration of the record. Fluctuations in sedimentation are observed between prehuman (0.087 cm.yr ${ }^{-1}$ : 95\% CI: 0.07 - 0.087) and Māori zones (0.03 cm/year: $95 \%$ CI: $0.02-0.31)$. The European zone experiences the highest sedimentation rate $(0.301$ cm/year: 95\% CI: $0.297-0.304)$ before declining during agricultural intensification $(0.219 \mathrm{~cm} /$ year: $95 \%$ CI: $0.183-0.255)$. 


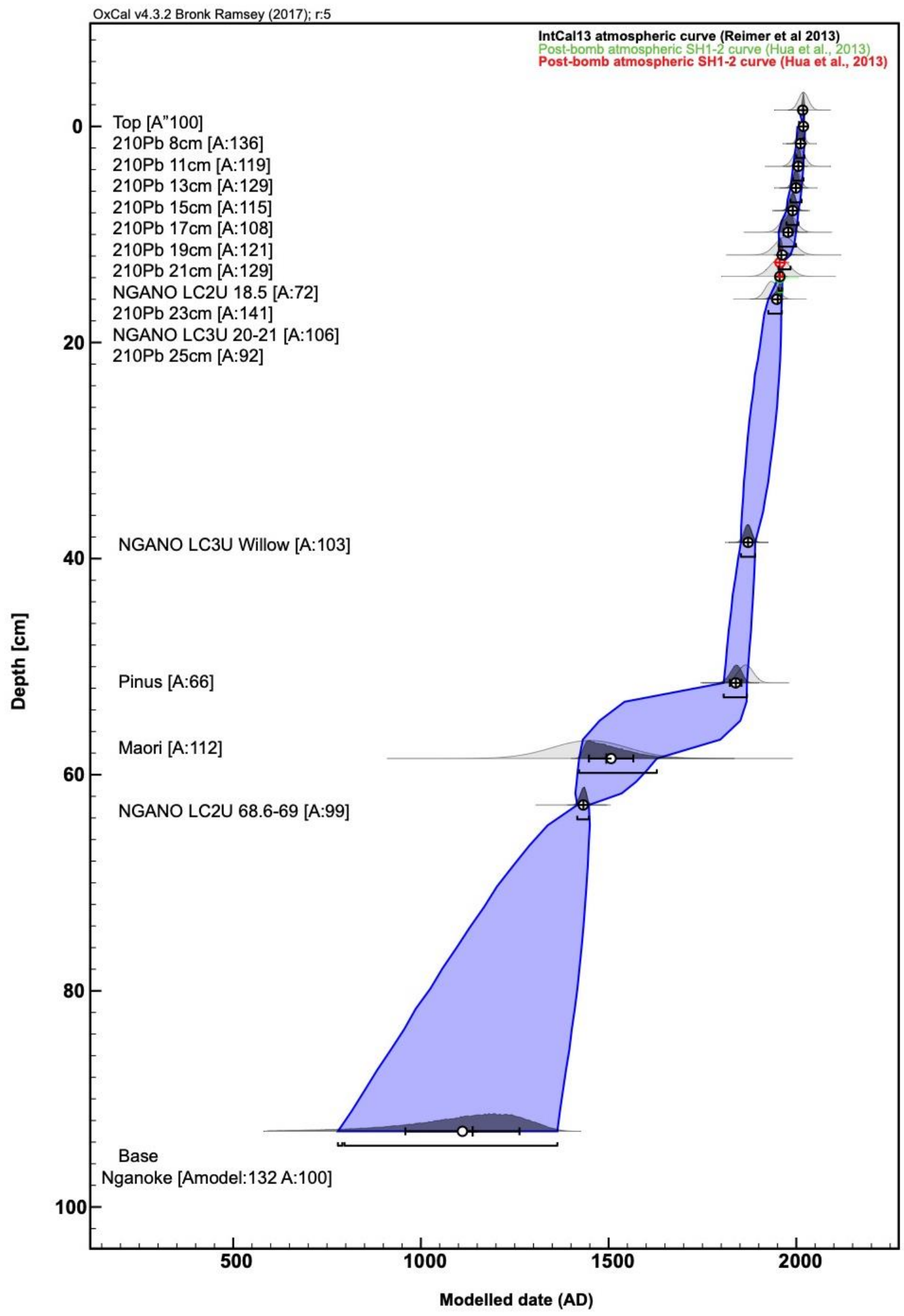

Figure 6.5: OxCal age model of Lake Nganoke sediment down core using depths correlated to a master core ( $\mathrm{LC3U})$. 


\subsection{LANDUSE RECONSTRUCTION}

\subsubsection{PALYNOLOGY}

A total of 16 samples were submitted for pollen analyses. Summarised in Figure 6.6, pollen records are described by zones and displayed as a percentage of the dryland pollen sum.

Pre-Human: Pre AD 1450

During the pre-human period ( $<$ AD 1450), terrestrial pollen is dominated by high abundances of Fuscospora (red beech, black beech, mountain beech and hard beech: 55.2\%), Dacrydium cupressinum Spp. (rimu: 21\%) and other Podocarps such as: Prumnopitys taxifolia (mataī) ; Podocarpus spp. (totora); Dacrycarpus dacrydioides (kahikatea) and Prumnopitys ferruginea (miro: all totalling 17.2\%). Elevated values of Cyathea Smithii \& Cyathea dealbata (fern pollen: $13.8 \%$ and 8.6\%) are also recorded. Holistically, tall trees remain the dominant vegetation (>95\%) until AD 1431, where the composition changes to $80 \%$ tall trees, $12.8 \%$ small trees and $6.8 \%$ herbs. A small charcoal spike (50-100 $\mu \mathrm{m}: 4.6 \%)$ is observed early in AD 1100 s.

Māori: AD 1450 - AD 1850

Representative of Māori arrival and occupancy on the landscape, this period is characterised by several noteworthy changes in pollen spectra. Fuscospora, D. cupressinum and other Podocarp pollen show a general decline accompanied by a marked arrival in AD 1490 of Poaceae (Gramineae: 6.8\%), Cyperaceae (Sedges: 18.2\%) and Pteridium esculentum (Bracken: 126.4\%). In contrast, small tree and shrub pollen concentrations do not decline post AD 1490 but rather increase (12.8\% to 20.3\% by AD 1700). Typha (Raupo) shows a distinct increase (by 30\%) towards the top of this zone (14.2\% to $37.7 \%$ by AD 1700). Furthermore, herb abundance increases from $8.2 \%$ to 49.4\% during the latter half of this zone (AD 1700-1850), with tall trees declining from $71.5 \%$ to $41 \%$. A sharp decline in charcoal abundance is also observed by AD $1700(68 \%$ to $27.5 \%$ ), before decreasing to $19.3 \%$ by $\mathrm{AD} 1849$.

European: AD 1850 - AD 1950

The European zone (AD 1850-1950) is characterised by the appearance and increase of exotic pollen types such as Pinus (9.6\% to $18.9 \%)$, Rumex acetosella ( $0.5 \%$ to $1.5 \%)$ and the detection of Salix (willow: 0.9\%) in AD 1873. Increasing abundancies in Poaceae pollen are identified between $\mathrm{AD} 1850$ to 1873 , combined with declining values of 
Pteridium esculentum (23.4\% to $4.3 \%$ by AD 1941) and the arrival of Potamogeton (Pondweed: 4.8\%) in AD 1850. Overall, tall and small trees begin to increase towards the end of the European period (rising 8\% from AD 1870 to 1941). Herb abundance begins to decrease in the second half of the zone (AD 1900 to 1950). A sharp decline in charcoal (charcoal 50-100 $\mu \mathrm{m}: 6.8 \%$ ) occurs at the start of the zone and there is a trend of decreasing abundance through the zone although a minor peak to13.8\% occurs at AD 1950

Intensification: $\mathrm{AD} \sim 1950$ - present

Exotic taxa, such as pine (28.8\%: AD 2019) continue to rise during the intensification period. Small fluctuations of Potamogeton (18.2\% peak in AD 1991, 13.5\% by AD 2019), Poaceae (trough of $39.6 \%$ in AD 2006 and 45.1\% by AD 2019) Typha, Cyperaceae and Macrocarpa dacrydiodes are also observed with Typha decreasing in abundance across the zone boundary. A sharp peak of Salix (5.2\%) is detected in 2006. The intensification period displays a continued trend of increasing tall trees (55.7\% peak in AD 2006), consistent abundance of small trees/shrubs and declining herbs. Charcoal abundance continues to decline. 


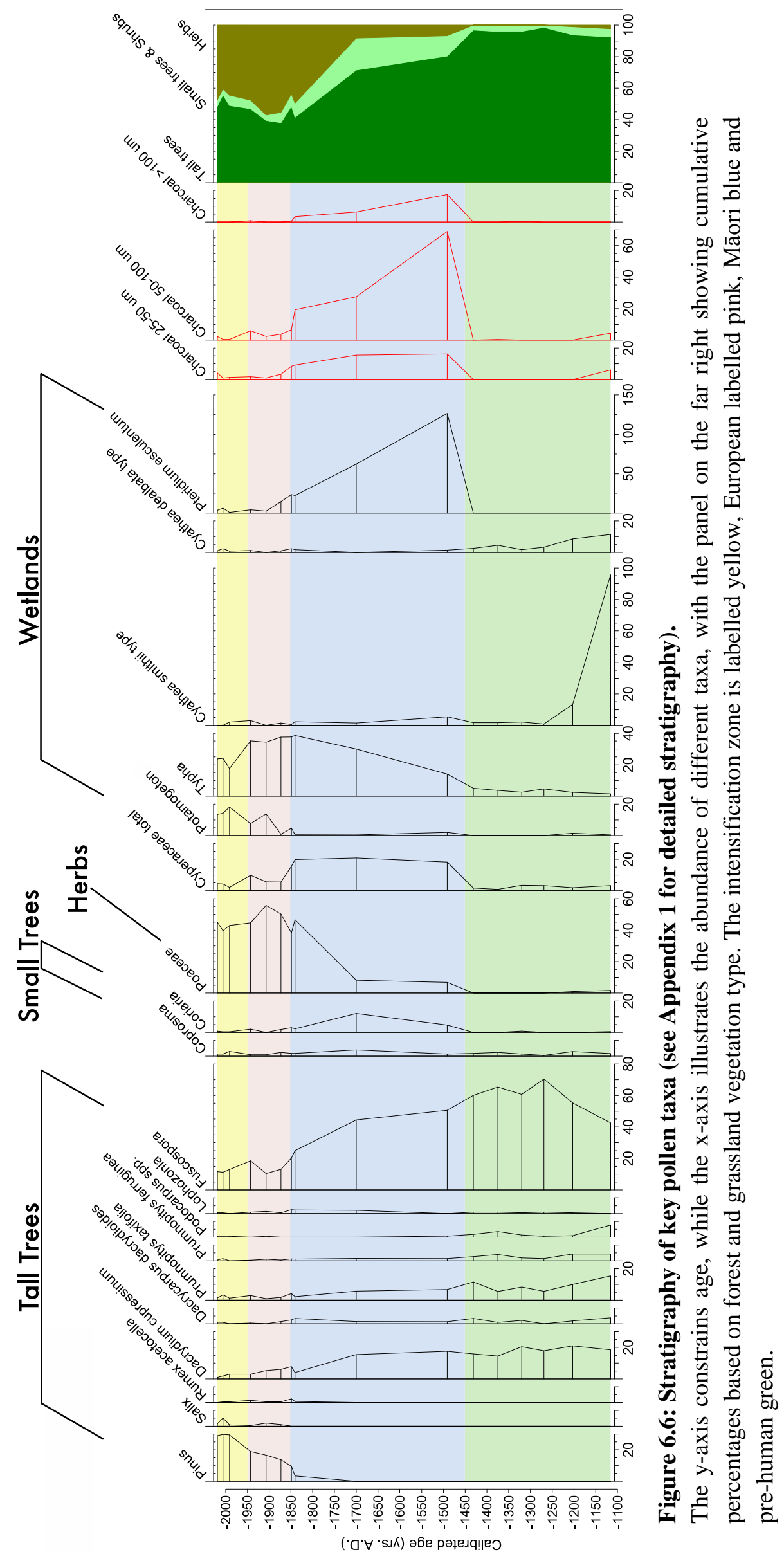




\subsubsection{ENVIRONMENTAL DNA - DDPCR}

The detection of bacteria associated with ruminants was used as an indicator of their abundance within the catchment. High gene copies (1900 and 1200 copies per gram) were observed at ages AD 1900 and 1946 (Figure 6.7). The trend dramatically increases post 1950, rising to 60,000 copies per gram (a measure of abundance) by the end of AD 2019.

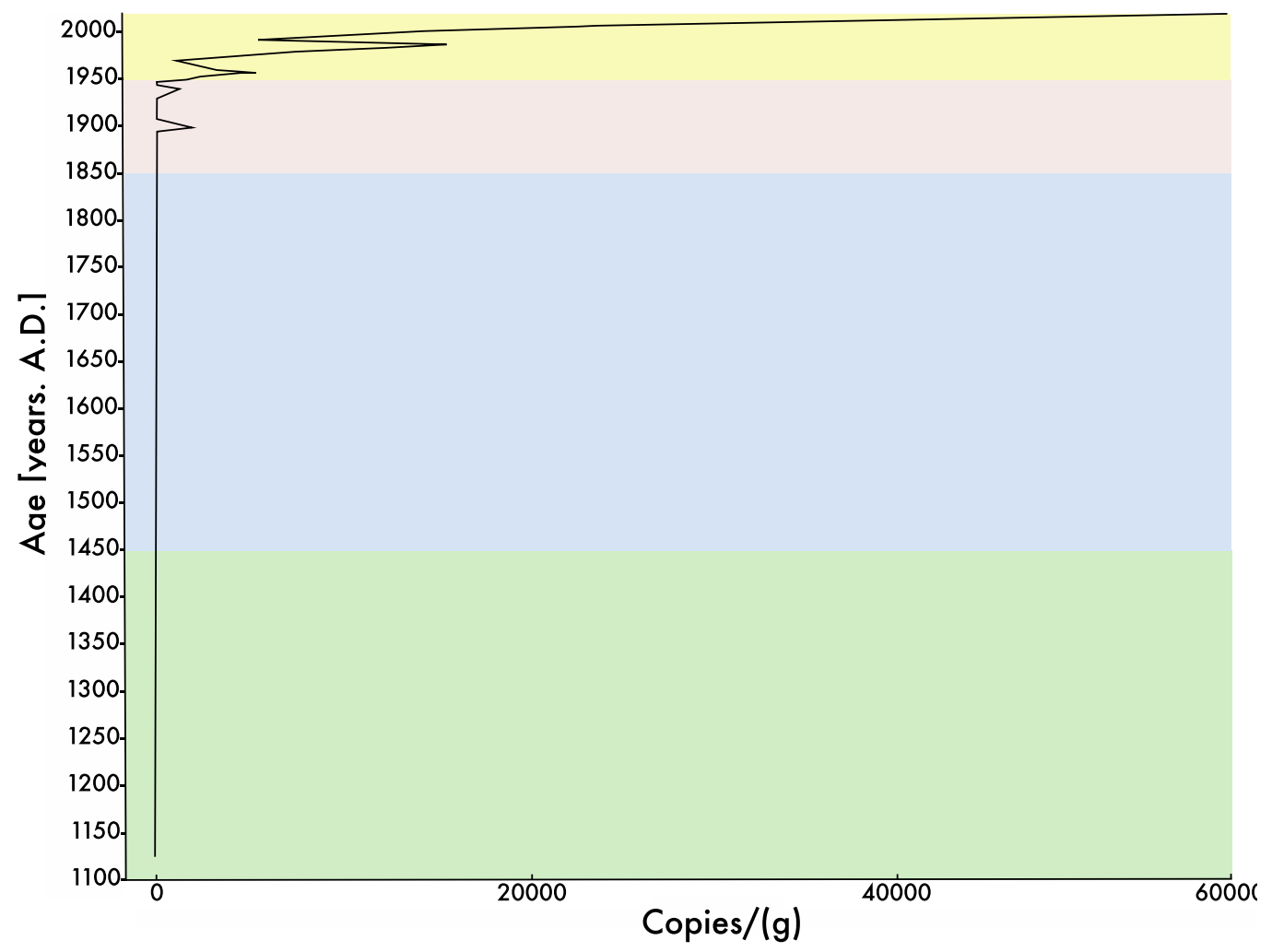

Figure 6.7: Digital droplet ruminant PCR of Lake Nganoke samples.

\subsubsection{GEO-CHEMICAL ANALYSIS}

A proxy for fertilisation application, cadmium abundance shows a slow incline from 0.08 to $0.12 \mathrm{mg} \mathrm{kg}^{-1} \mathrm{DW}$ (dry weight) during pre-human and Māori occupation. Cadmium increases throughout European landuse and again during intensification to more than double the values of previous zones $\left(0.3 \mathrm{mg} \mathrm{kg}^{-1} \mathrm{DW}\right)$. A small decrease is highlighted at $\sim$ AD 1995. Total nitrogen rises relatively steadily during Māori occupancy to $8000 \mathrm{mg}$ $\mathrm{kg}^{-1}$ DW prior to fluctuations within the European Zone $\left(7500-8200 \mathrm{mg} \mathrm{kg}^{-1} \mathrm{DW}\right)$. Increasing post $\mathrm{AD} 1950$, total nitrogen reaches levels of $10,000 \mathrm{mg} \mathrm{kg}^{-1} \mathrm{DW}$ by $\mathrm{AD}$ 2019.

Following a similar trend, total carbon flux is relatively low ( $\left.<6000 \mathrm{mg} \mathrm{kg}^{-1} \mathrm{DW}\right)$ during pre-human landuse before rising dramatically post AD 1550 from $5800 \mathrm{mg} \mathrm{kg}^{-1} \mathrm{DW}$ to more than $8000 \mathrm{mg} \mathrm{kg}^{-1} \mathrm{DW}$ by AD 1800. During the European zone, carbon flux follows a similar trend to cadmium and total nitrogen with a sharp peak in the mid to late 1800 s. 
Carbon flux increases from $7800 \mathrm{mg} \mathrm{kg}^{-1} \mathrm{DW}$ to $95000 \mathrm{mg} \mathrm{kg}^{-1} \mathrm{DW}$ during the first half of the intensification period (AD 1950 to AD 1965). Post AD 1970, carbon flux declines to 9000 by AD 1980 before increasing to $10,000 \mathrm{mg} \mathrm{kg}^{-1} \mathrm{DW}$ by AD 2019. A measure of organic matter provenance, carbon to nitrogen ratios decline (by 1.2) from AD 1450 to AD 1550. Ratios rise within the Māori zone to reach 11.5 by the start of the European period (AD 1850) before dropping to 10.5 in $\mathrm{AD} 1860$. A general trend of decline is observed after AD 1930, for which ratios of carbon to nitrogen reach 10 by AD 2019.

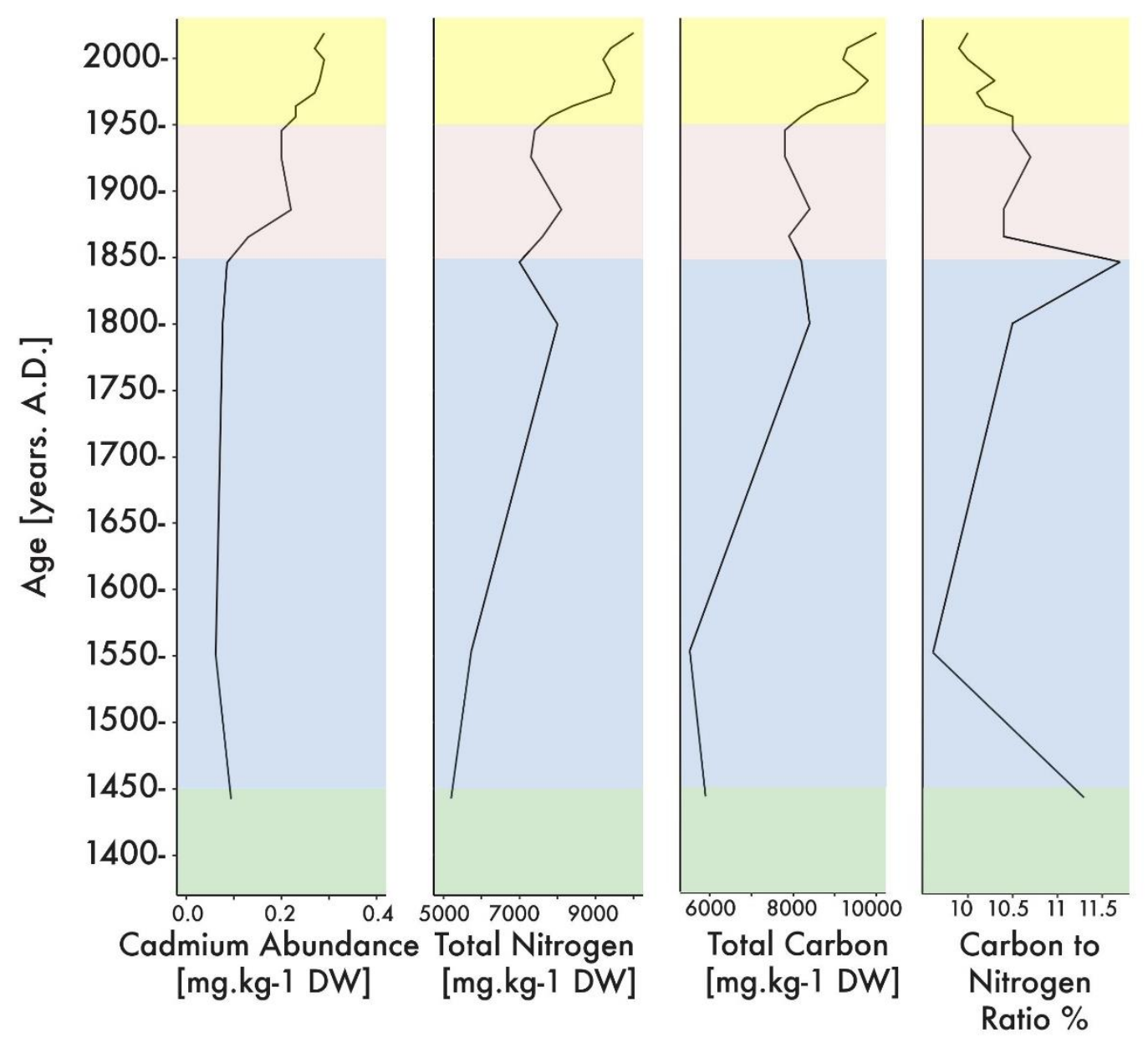

Figure 6.8: Geo-chemical analysis of cadmium, total nitrogen , total carbon and carbon to nitrogen ratio (C: $\mathrm{N}$ ratio).

\subsection{LAKE ECOSYSTEM AND WATER QUALITY RECONSTRUCTION}

\subsubsection{BACTERIAL METABARCODING - (16s rRNA)}

Amplicon sequence variants (ASV's) refer to the individual DNA sequences recovered from a sample. A total of 44,040 bacterial ASV's were recovered from 47 samples within Lake Nganoke. A total of 27 bacterial phyla were identified (Figure 6.9), with Proteobacteria, Chloroflexi and Acidobacteria displaying the highest total number of ASV's. A total of 11 phyla were identified with mean percent abundances greater than 
one (Figure 6.10). Chloroflexi, Proteobacteria and Spirochetes had the largest changes in percentage $(>20 \%)$.
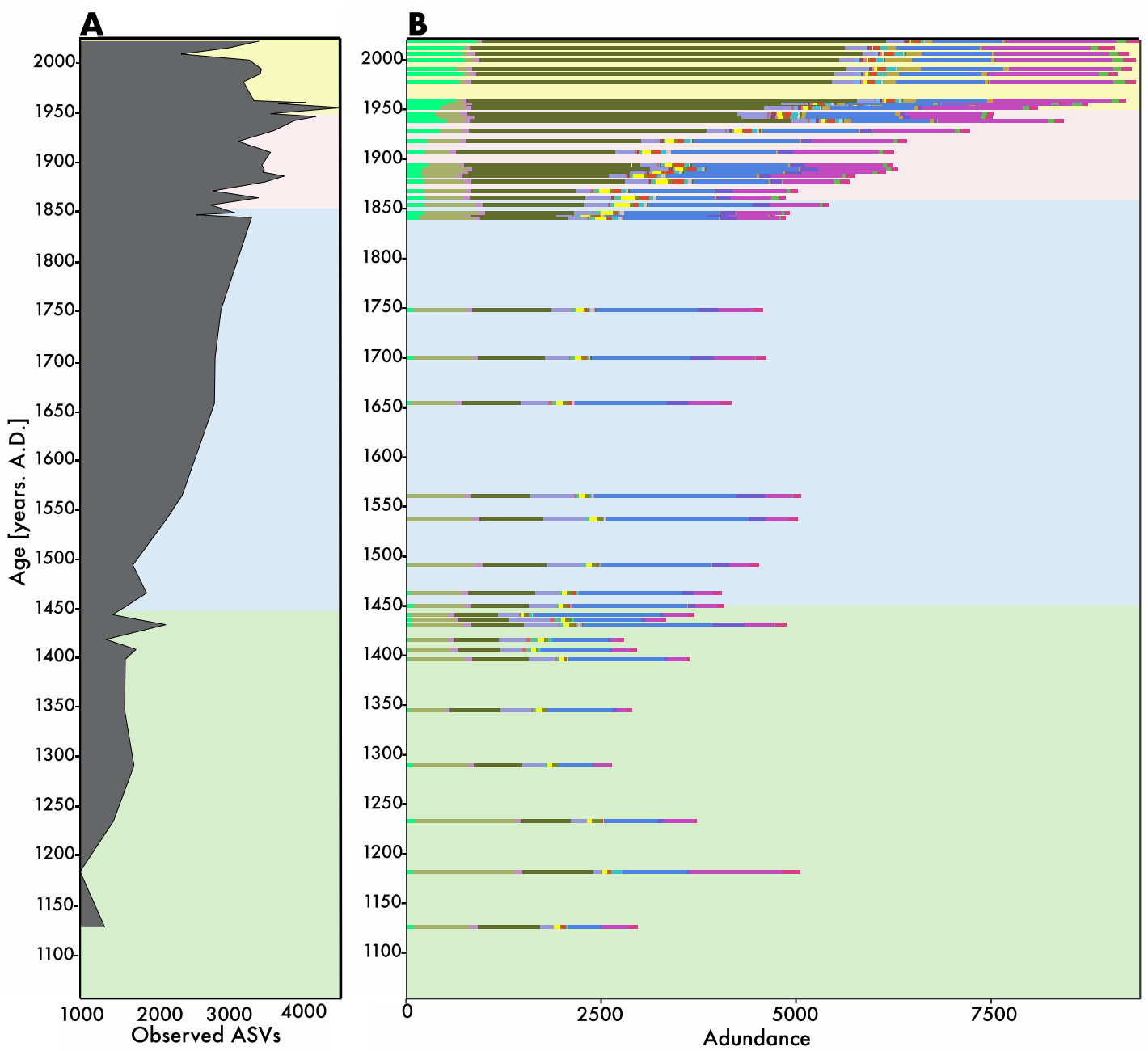

\section{Phyla}

\begin{tabular}{|c|c|}
\hline Acidobacteria & Cyanobacteria \\
\hline Actinobacteria & Dependentiae \\
\hline Bacteroidetes & Elusimicrobia \\
\hline Caldiserica & Epsilonbacteraeota \\
\hline Calditrichaeota & Fibrobacteres \\
\hline Chlamydiae & Firmicutes \\
\hline Chloroflexi & Gemmatimonadetes \\
\hline
\end{tabular}

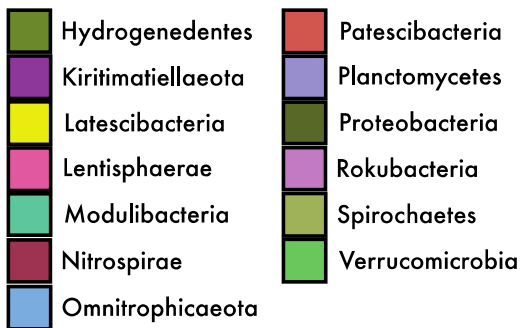

Figure 6.9: Taxonomic richness (Observed ASV's) (A) and composition (reads per samples) (B) of Lake Nganoke at Phylum level. 

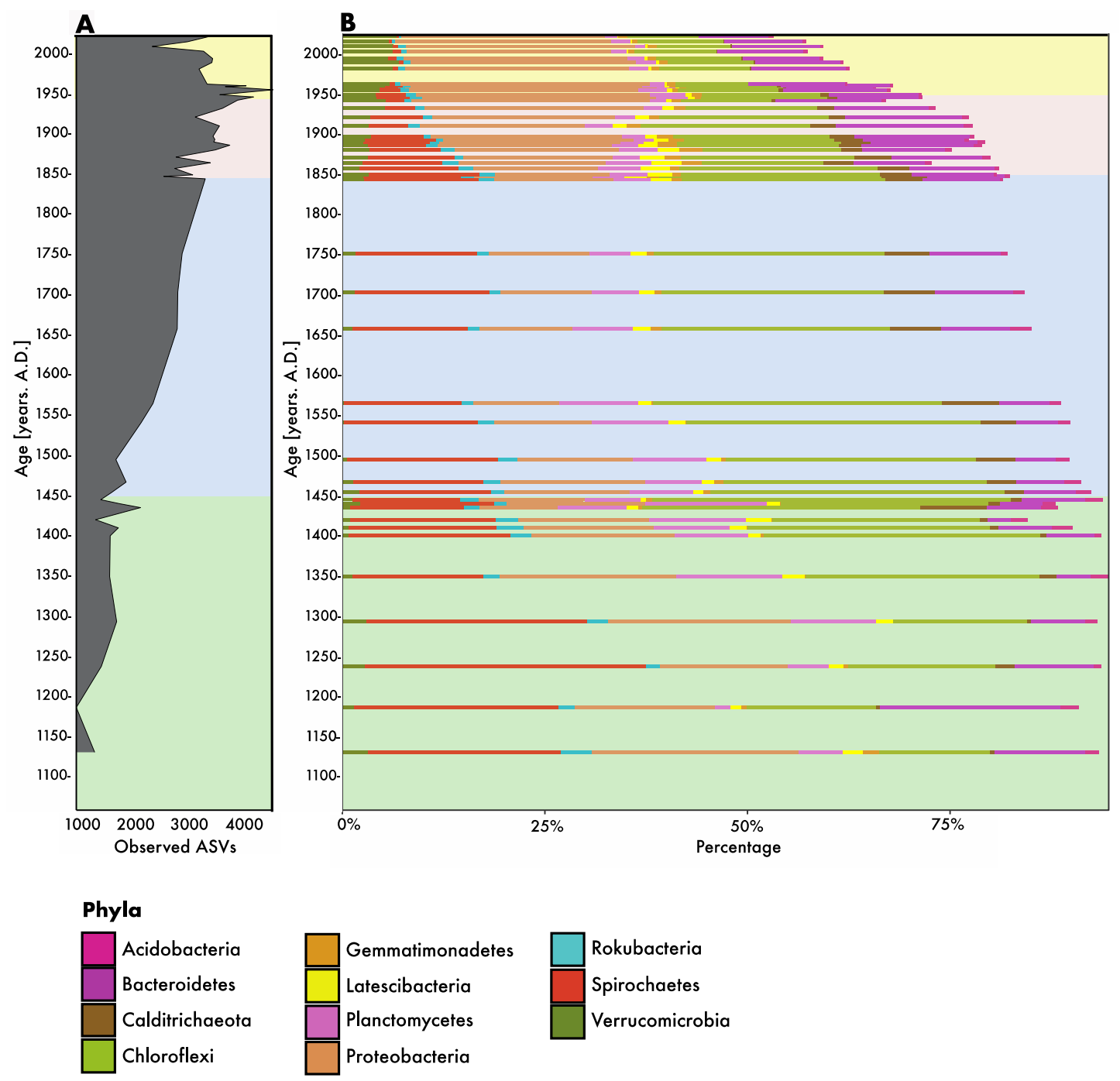

Figure 6.10: Taxonomic percentage richness (Observed ASV's) and abundance (reads per samples) (B) of Lake Nganoke at Phylum level.

This figure only includes phyla that have a mean greater than one.

A non-metric multidimensional scaling plot was used to illustrate the difference in taxonomic composition between zones. Figure 6.11 displays a clear dissimilarity in species composition between intensification, European, Māori and pre-human, as no two zones cluster together. Two major trends are highlighted: axis one where intensification, European, and Māori are separate from each other and axis two where Māori and prehuman are separated. This may imply that the Māori zone is different from the rest. The Adonis statistical test, with a p-value of 0.001 , confirms all four zones are significantly different from one another. 


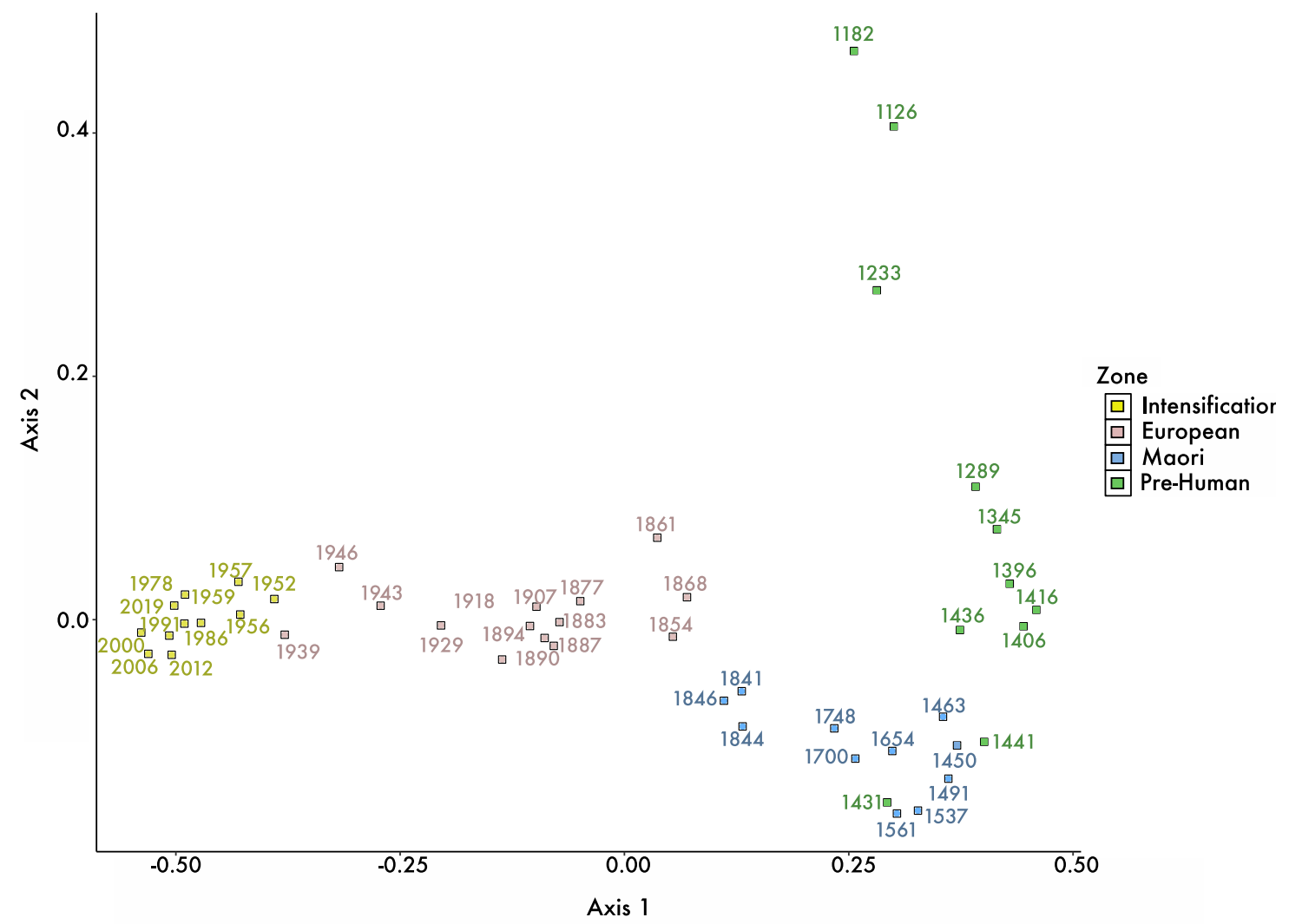

Figure 6.11: Two-dimensional non-metric multidimensional scaling plot displaying taxonomic differences between landuse zones .

Dissimilarity matrix was made using the Bray-Curtis dissimilarity distance, before being plotted on the NMDS.

As identified within Section 2.5.2 Nitrospirae, Proteobacteria, Cyanobacteria and Atribacteria have the potential to provide insight into historical changes within lake water quality and bacterial ecosystems. All four phyla are plotted within Figure 6.12 at class level, with Nitrospirae consisting primarily of Thermodesulfobrionia, with lower overall concentrations of the classes Nitrospira and 4-29 (<1\% ASVs per sample) (4-29 ASV currently unidentified at class level). Further descriptions of the observed trends are explored below and classified within the zones established in Section 4.2. 

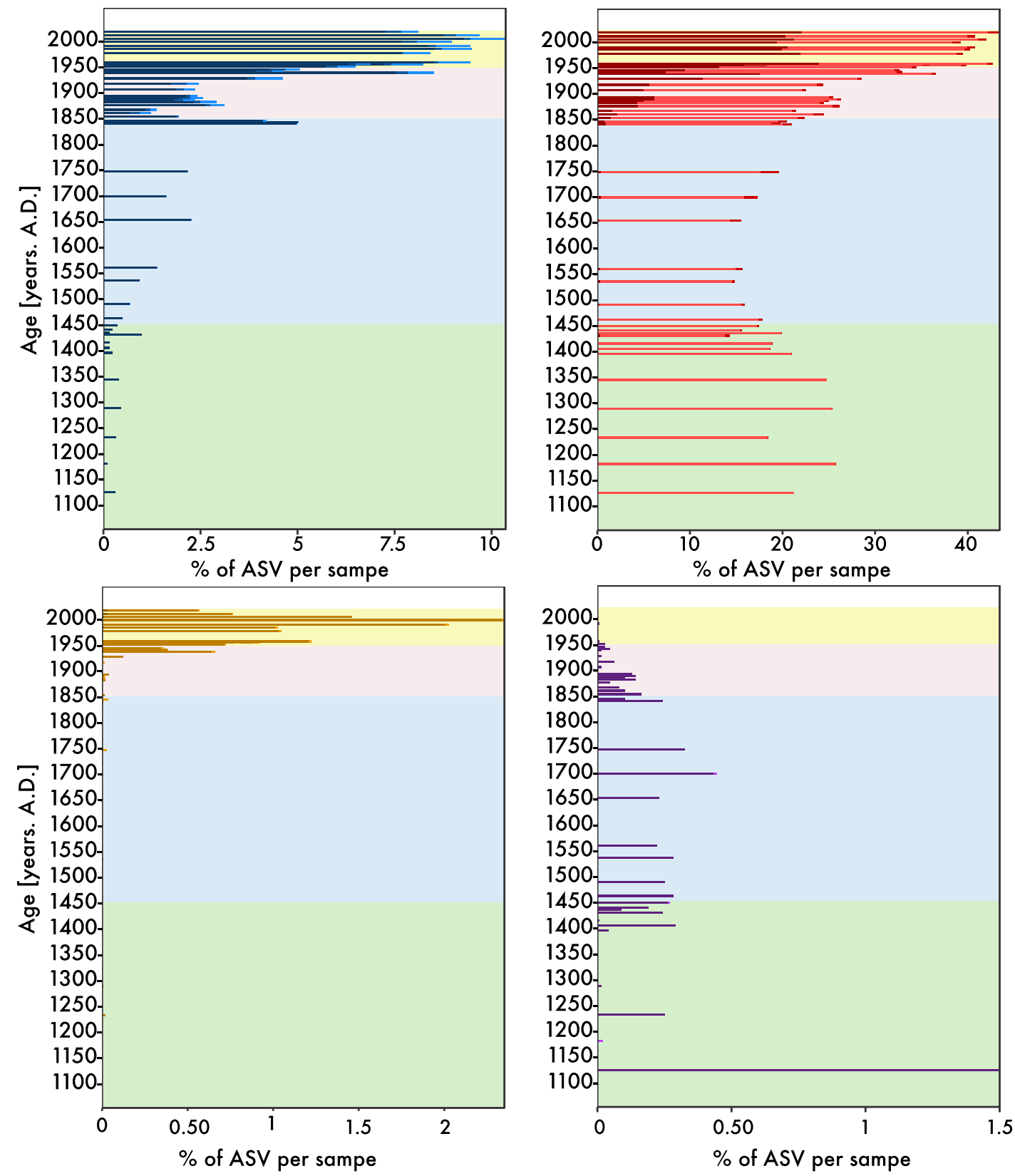

\section{Nitrospirae}

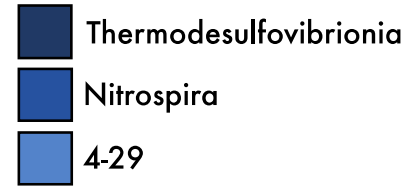

\section{Cyanobacteria}

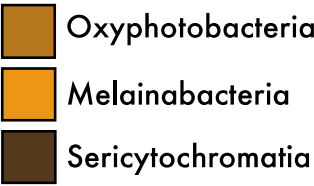

\section{Proteobacteria}

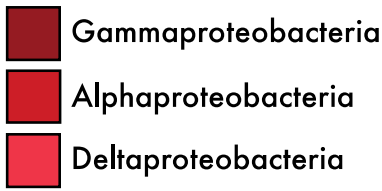

\section{Atribacteria}

JS 1

Caldatribacteria

Figure 6.12: Taxa indicative of changes in lake water quality and ecosystem health identified through literature.

Identified taxa consist of Phyla Nitrospirae (classes Thermodesulfovibrionia, Nitrospira and 429 - Blues), Proteobacteria (classes Gammaproteobacteria, Alphaproteobacteria and Deltaproteobacteria - Reds), Cyanobacterian (classes Oxyphotobacteria, Melainabacteria and Sericytochromatia - Golds) and Atribacteria (classes JS1 and Caldatribacteria - Purples) 
Pre-Human: Taxonomic composition is relatively low in diversity(max $<5000$ reads) during the pre-human zone (Figure 6.9). Three taxa (Spirochetes, Proteobacteria and Bacteroides) dominate Lake Nganoke's lake bacteria community, remaining relatively stable throughout (Figure 6.10). Chloroflexi increases during this zone from $15 \%$ to 37.5\%. Indicator taxa Nitrospirae and Atribacteria display consistent ASV's per sample throughout this zone with the exception of a peak (>1.5\%) at approximately AD 1125 (Figure 6.12). Proteobacteria shows a slight decline (26\% to $22 \%$ ), with the class Alphaproteobacteria the main taxa present. Of particular importance, there is a small abundance of ASVs for Cyanobacteria and no proteobacteria class Gammaproteobacteria are seen within the pre-human zone.

Māori: Taxonomic composition during the Māori zone is relatively low diversity and consistent with reads generally below 5,000 (Figure 6.9). Percentages of taxa largely stay the same across the zone with the exception of Chloroflexi, which decreases slightly (35\% to 29\%) from AD 1450 to AD 1500) (Figure 6.10). Indicator taxa Thermodesulfobrionia increases from $0.3 \%$ to $5 \%$ by mid $\mathrm{AD} 1800$, while Alphaproteobacteria remains relatively constant $\sim 17 \%$ within the zone (Figure 6.12). No ASV's of Cyanobacteria are present from AD 1450 to 1850 .

European: The European zone is characterised by a noticeable increase in taxonomic composition (5,000 to 7,600 reads), with Proteobacteria displaying a largest increase (1,500 reads to 4,300; Figure 6.9). Verrucomicrobia (2\% to 6\%) and Proteobacteria (18\% to $30 \%$ ) change dramatically, exhibiting increases within the zone. Conversely, Spirochetes (17\% to $2 \%)$ and Chloroflexi (25\% to $18 \%)$ display declines in percentage per sample from AD 1850 to AD 1950 (Figure 6.10). Concerning indicator taxa, Thermodesulfobrionia experiences a rapid decline post AD $1850(\sim 1 \%)$ before increasing to $7.5 \%$ by the start of $\mathrm{AD} 1950$ (Figure 6.12). Both Gammaproteobacteria and Alphaproteobacteria display increases throughout this zone (Alphaproteobacteria from $20 \%$ to $40 \%$ and Gammaproteobacteria from $2 \%$ to $20 \%$ ). Of significance, this is the first time Gammaproteobacteria is observed within Lake Nganoke's sedimentary records. While percentages of Cyanobacteria are relatively low (>0.01) pre-AD 1930, percentages of Oxyphotobacteria increase to $0.75 \%$ by the start of AD 1950. Conversely, measurements of JS1 decrease post AD 1850 to approximately $0.03 \%$. 
Intensification: Taxonomic composition remains high $(>7,500$ reads) throughout the intensification period, with little change in the abundance (reads) of species (Figure 16). Observed ASV's drop rapidly following AD 1950, from 4,000 to 3,500, falling again in the early 2,000s to 2,200 ASVs per sample (Figure 6.9). Percentages of Verrucomicrobia, Proteobacteria, Chloroflexi and Actinobacteria remain relatively constant throughout the timeframe, with Spirochetes declining to 0 reads per sample by 2019 (Figure 6.10). Indicator taxa Thermodesulfobrionia remains relatively stable $(\sim 8.5 \%)$ throughout the intensification zone, as does Gammaproteobacteria ( 20\%) and Alphaproteobacteria ( $40 \%$ ) (Figure 6.12). Oxyphotobacteria increases post AD 1950, peaking at $\sim 2.2 \%$ in AD 2000 before declining to $0.5 \%$ by 2019 . No values of JS1 are presented within the intensification zone.

\subsubsection{HYPERSPECTRAL IMAGING}

The 660/670 RABD averages are well below the mean for the duration of Māori zones with an index range of 1.02 to $1.06 \mathrm{RABD}$ at $\sim 680 \mathrm{~nm}$ (Figure 6.13). Peaks are recorded at $\mathrm{AD} 1340$ and $\mathrm{AD}$ 1420, reaching levels over the 1.803. During the European period, the levels increases above the mean to a peak above 1.10 , rising sharply during the Intensification Zone, to end at 1.18 by 2019 . 


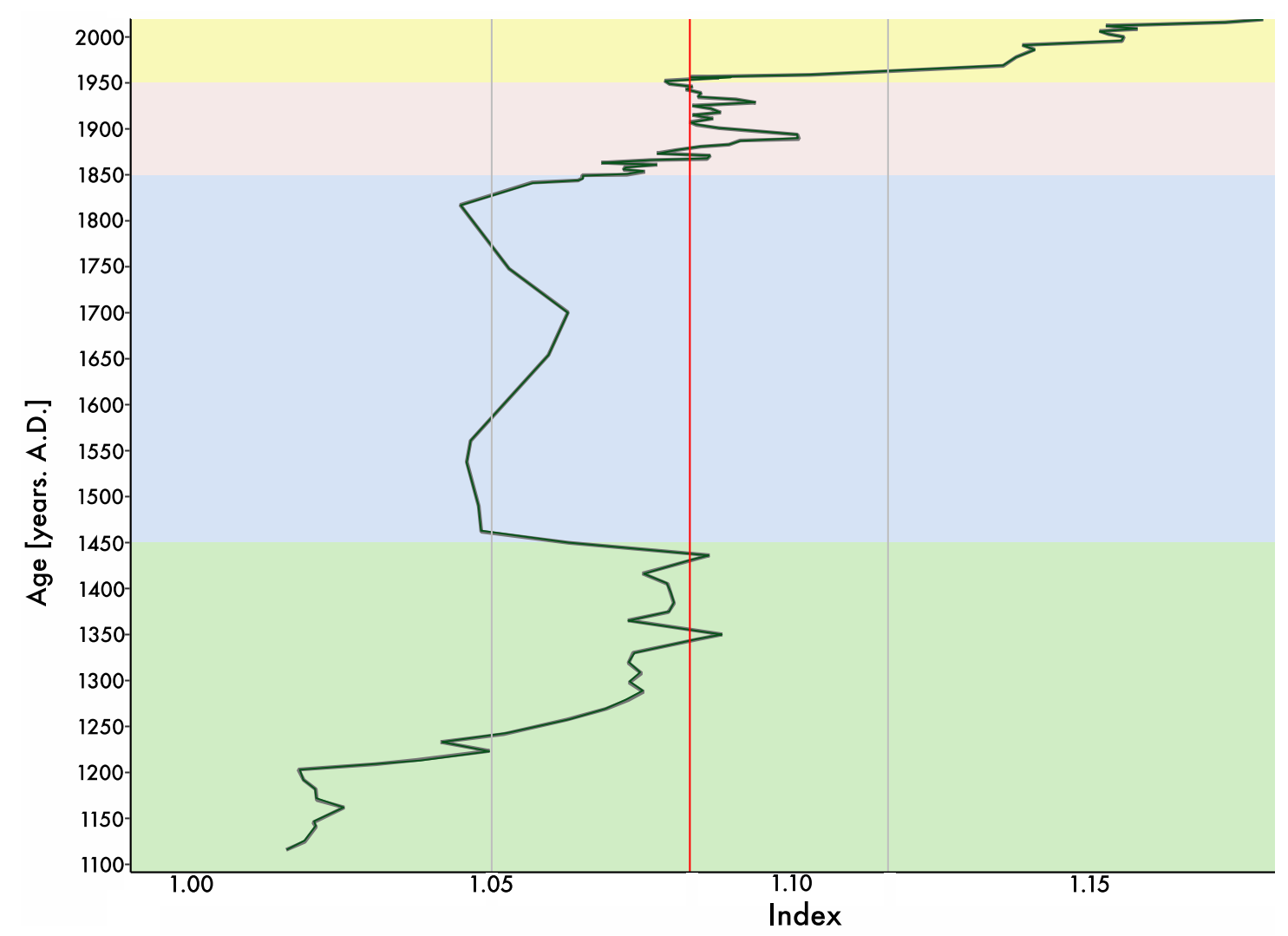

Figure 6.13 Hyperspectral ratio of the $660 / 670 \mathrm{~nm}$ band (green) in Lake Nganoke with mean value of 1.803 (red) and standard deviation of 0.033 (grey).

In order to estimate chlorophyll content, measurements are taken of the reflective absorption band at $\sim 660 / 670 \mathrm{~nm}$, with the data averaged at each depth $(1 \mathrm{~cm})$ to minimise noise.

\subsubsection{PHOSPHOROUS FRACTIONATION}

The residual phosphorous fraction profiles with age are presented as this is the least mobile fraction (Figure 6.14). The residual fraction trends upwards (>200 $\mathrm{mg} \mathrm{kg}^{-1} \mathrm{DW}$ ) until AD 1800 before dropping dramatically at the start of the European period. A sharp increase in the intensification period is observed post AD 1950 rising from $150 \mathrm{mg} \mathrm{kg}^{-1}$ DW to $290 \mathrm{mg} \mathrm{kg}^{-1} \mathrm{DW}$. 


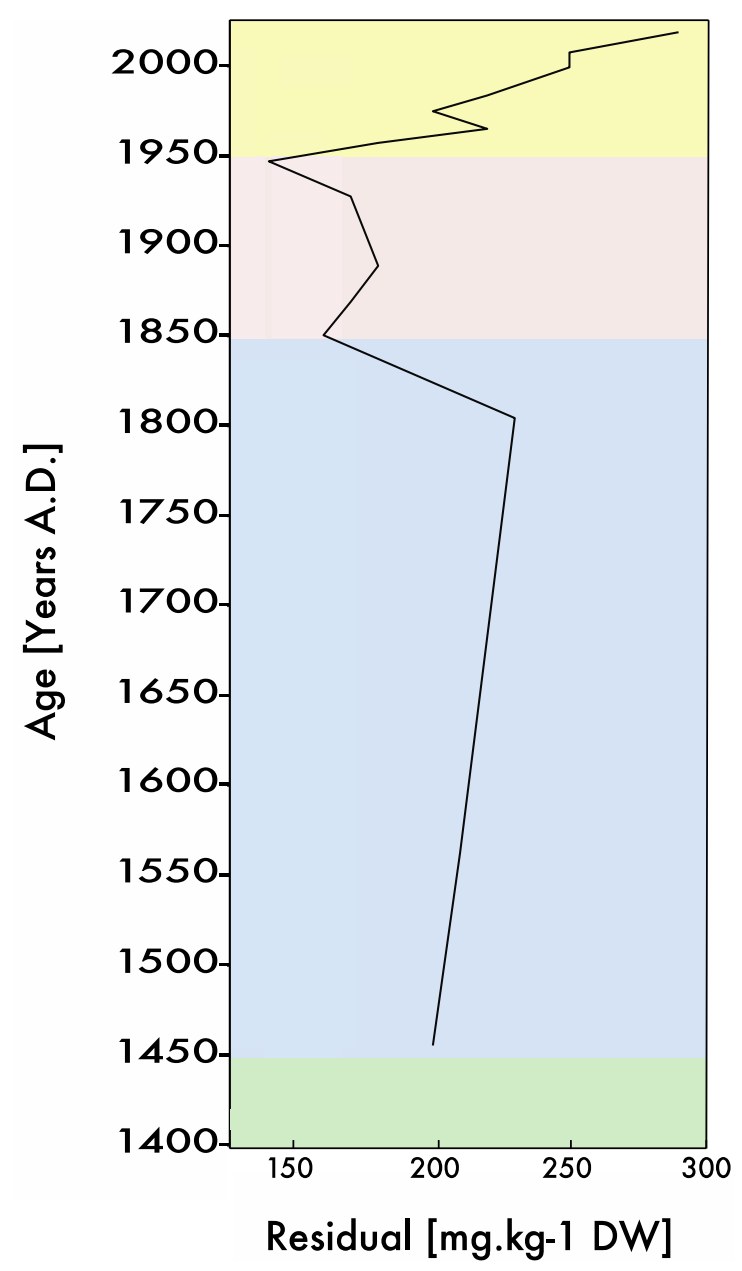

Figure 6.14: Fraction of residual $P$

\subsection{AERIAL PHOTOGRAPHY}

Historical air photography provides evidence of two strips of riparian zones in the Lake Nganoke catchment (Figure 6.15). The first, lake marginal riparian is located at the southern end of the lake and is the major area to receive planting and growth during the timeframe captured by available aerial photography. A lack of vegetation indicates the riparian as absent in AD 1944 and present in AD 1962. Growth of the lake marginal riparian is hence defined as post AD 1944 with maturity established by AD 1973, after which its size remains constant through to $\sim$ AD 2013. Average width is defined as $5 \mathrm{~m}$.

The second, stream marginal riparian is present prior to $\sim \mathrm{AD} 1944$, and located to the south east of Lake Nganoke and covers the entire fluvial catchment. The composition of the riparian is mainly native with some plantation pine. The catchment riparian reached maximum size in AD 1961, with an average width of $30 \mathrm{~m}$. Large amounts of deforestation from $\sim$ AD 1961 to 1973 lower the number of tall trees within the catchment 
and therefore size. Changes in Pinus pollen abundance can provide some insight into the timing of maturity reached within this zone.

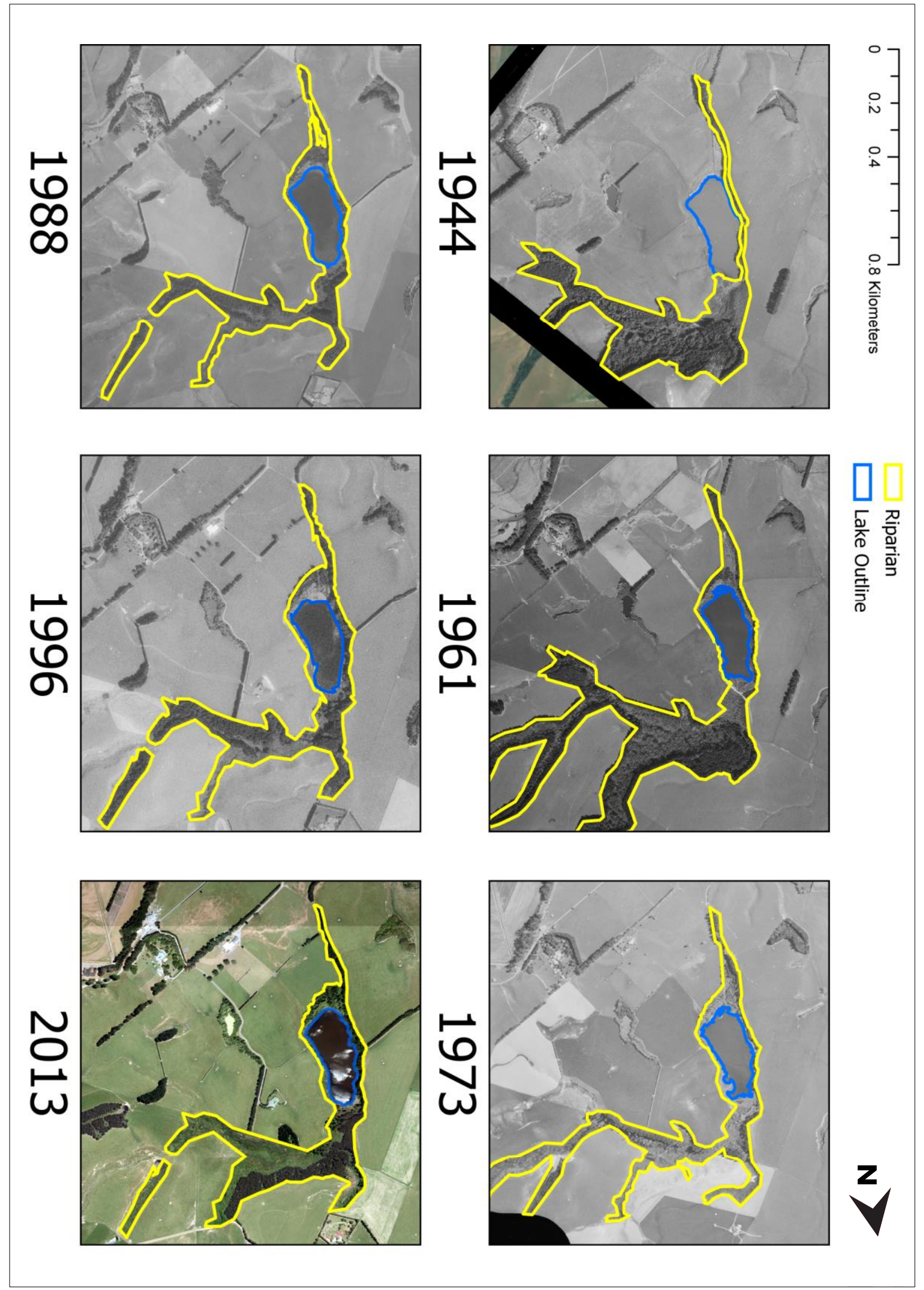

Figure 6.15: Historical air photographs of Lake Nganoke (blue) and riparian change (yellow) from 1944 to 2013 


\section{CHAPTER 7: DISCUSSION}

Chapter 7 aims to reconstruct environmental change at Lake Nganoke, to examine the impacts of landuse intensification on lake ecosystems and water quality. Two hypotheses are tested, 1) whether anthropogenic landuse intensification in the Lake Nganoke catchment has resulted in ecosystem change and a decrease in water quality from prehuman baselines through to Māori subsistence, European agriculture and intensification;

2) whether the planting of a riparian zone around the lake has buffered lake water quality against agricultural intensification.

In order to achieve this aim, a chronology of pre-human, Māori, European and intensification landuse regimes within Lake Nganoke's catchment is generated, with specific reference to a high-resolution record of agricultural intensification over the last 180 years (Sections 7.1.1, 7.2.1, 7.3.1, 7.4.1). Furthermore, a record of lake water quality, ecosystem evolution and nutrient loading as a response to drivers of landuse change is investigated (Sections 7.1.2, 7.2.2, 7.3.2, 7.4.2). Following environmental reconstruction, the effectiveness of riparian zones in mitigating agriculturally enriched nutrients fluxes is assessed (Section 7.5). The discussion will relate to the summary Figures 7.1 on page 66. 


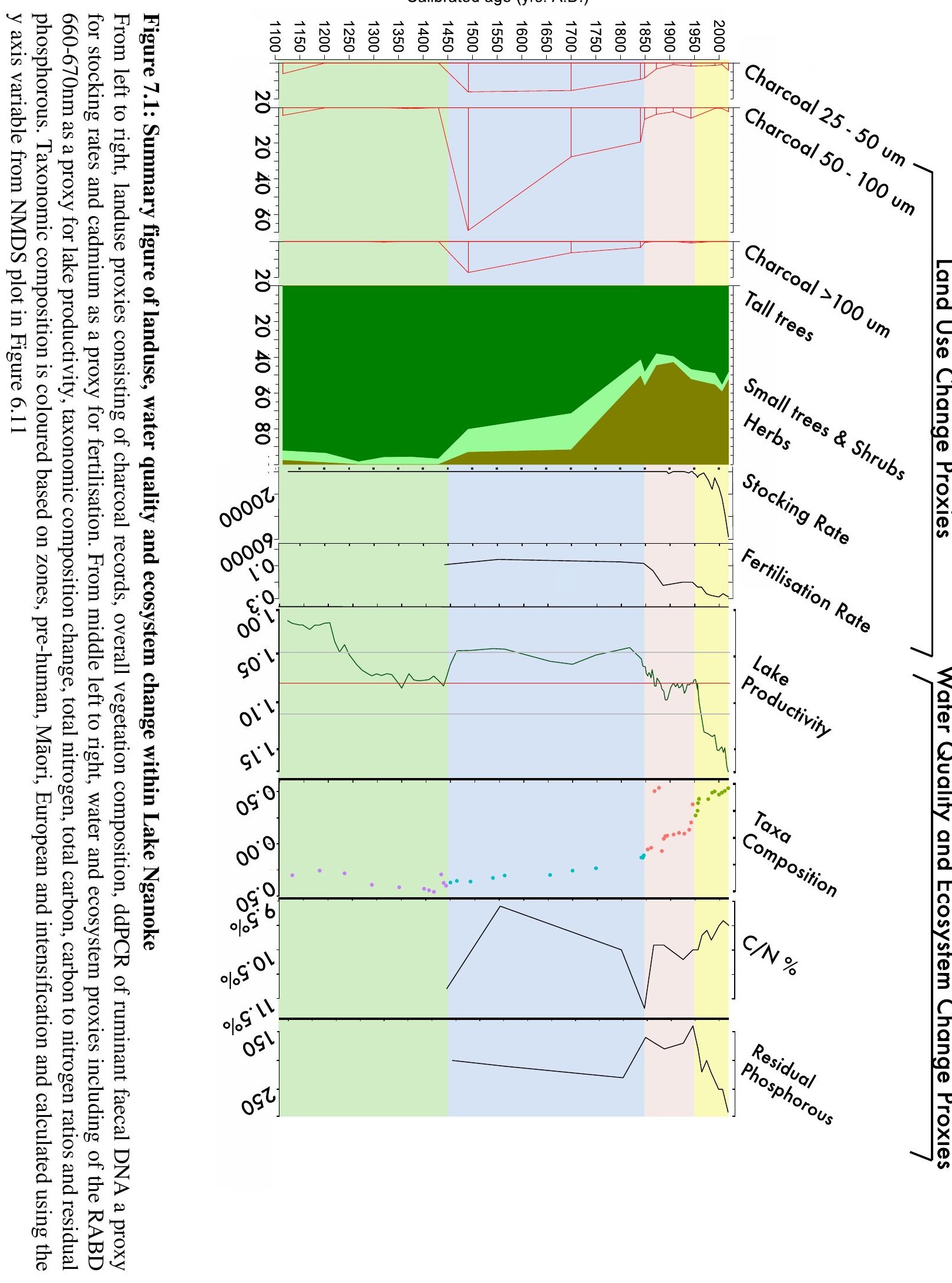




\subsection{PRE-HUMAN VEGETATION: PRE AD 1450}

\subsubsection{LANDUSE}

Consistent with findings by Hill (1963b) and Wardle (1991), the pollen record of prehuman vegetation largely consists of tall trees. Primarily Fuscospora and Dacrydium cupressinum; this indicates the majority of the catchment was forested. Fuscospora is typically a light demanding canopy tree that prefers deep, fertile, well-drained soils and low elevation (Stewart \& Rose, 1990). While these preferences are true for red beech, mountain beech (which are also included within Fuscospora pollen types) can grow to forest tree lines (Okuda et al., 2002). However, due to the land surrounding Lake Nganoke being primarily lowland plains, the predominant beech within Fuscospora pollen is therefore likely red beech situated at low elevation, although it is important to note that beech pollen is relatively mobile. Podocarps, of which rimu is the most common, are historically categorized as emergent, forming pure stands to the exclusion of Fuscospora (Wardle, 1967). The catchment during this period is therefore likely well-vegetated, with Fuscospora located on dry spurs and ridges while Podocarps dominate the lower hills and plains.

\subsubsection{RESPONSE OF LAKE ECOSYSTEM AND WATER QUALITY CHANGE}

Measurements of RABD 660-670 nm provide a proxy for sediment chlorophyll a that is usually interpreted as an autochthonous productivity signal (Butz et al., 2015). Productivity pre-human arrival at Lake Nganoke is relatively high for the record, on par with the lowest values observed within the European era. The single measurement of $\mathrm{C}: \mathrm{N}$ ratio of $\sim 10$ at $\sim \mathrm{AD} 1444$ demonstrates that organic material was primarily algae in origin, with values $>20$ from terrigenous origin while values $<10$ signifying algae origin (Herczeg et al., 2001). Therefore, measurements of RABD are likely autogenic (derived from algae. Measurements of RABD 660-670 are therefore likely the result of in-lake productivity which demonstrates average rates of organic biomass production from 1300 to $1440 \mathrm{AD}$. Caution however must be taken when considering measurements of $\mathrm{C}: \mathrm{N}$ and residual $\mathrm{P}$ as they only have one sample, located near the end of the zone boundary (AD 1440). Low productivity observed at the bottom of the core is likely related to a different depositional environment (i.e. light grey laminated silt), potentially explained through the shallow marine embayment historically observed as occupying most of the Southern Wairarapa pre $3 \mathrm{ka}$. This was outlined earlier in Section 4.1. 
Taxonomic composition of bacterial flora within Lake Nganoke remains constant throughout the pre-human zone, suggesting a stable environment. Indicator taxa, like Deltaproteobacteria and Atribacteria, remain constant throughout the zone. While Deltaproteobacteria's continuous relative abundance suggests nitrifying nutrient input, Atribacteria points towards anerobic conditions. It is hard to imagine a 3-m deep lake would thermally stratify; however, this could have been encouraged by wind protection from a closed-canopy forest. More likely, however, oxygen depletion was driven by inlake productivity and algal blooms (Schindler, 2006). The nutrient source driving these blooms prompts further investigation, but, from the $\mathrm{C}: \mathrm{N}$ ratios, nutrients are not observed to originate from terrestrial vegetation. One potential source could include waterfowl nutrient loading, as bird life was prolific prior to human arrival in New Zealand (Worthy et al., 2017; Cole \& Wood, 2018). Higher rates of algal productivity could therefore be driven by high abundances of bird populations inhabiting Lake Nganoke, further supporting internal lake nutrient loading. Additional research into molecular markers for historic bird life would better quantify this hypothesis. Finally, higher rates of algal productivity have serious implications for the NPS-FW and restoration efforts, as not all lakes necessarily have oligotrophic baseline states (Ministry for the Environment, 2014).

\subsection{MĀORI: AD 1450 - 1850}

\subsubsection{LANDUSE CHANGE}

This zone is characterised by large increases in the influx of charcoal (>100 um), a decline in tall trees, and an increase in grasses, shrubs, Pteridium and Typha. Similar transition from closed-canopy forests to Pteridium and early-successive shrubs and grasses is well documented within New Zealand palynology records and interpreted to be the result of Polynesian land clearance (McGlone, 1983b; Sutton, 1987; McGlone, 1989b; Elliot et al., 1995; Newnham, Lowe, \& Matthews, 1998; Byrami et al., 2002; Ogden et al., 2006; McWethy et al., 2009; Abrahim et al., 2013; Walter et al., 2017). Increases in Pteridium linked with influxes of > 100 um charcoal found within Lake Nganoke sediments indicate localised land clearance for subsistence practices (McWethy et al., 2009; McWethy et al., 2014; Trodahl et al., 2016a). Pteridium is an important source of carbohydrate for Polynesian settlers. Interestingly, a further increase in deforestation can be observed post $\mathrm{AD} 1700$, with an additional decline in tall trees and a continuation of charcoal burning. This may be indicative of further Māori landuse, or resettlement within Lake Nganoke's catchment or possibly the product of a sampling artefact. A higher 
resolution pollen analysis on the Lake Nganoke record is required to determine the most appropriate explanation of the substantial decline in tall trees post AD 1700.

Historic Māori land clearance, however, was typically small scale and localised, intended to clear undergrowth for the cultivation of food related taxa (Wardle, 1985). Within Lake Nganoke's catchment, evidence of small localised fires are reinforced through relatively high abundances of $>100-\mu \mathrm{m}$ charcoal suggesting burning of local origin (Higuera et al., 2007; Oris et al., 2014) and the continued presence of tall trees which precludes large tracks of regional deforestation. Interestingly, while Podocarps are inferred to most likely have dominated the forest on the plains surrounding Lake Nganoke, they only decline marginally through the pre-human Māori transition; further supporting the argument for clearing being localised.

Paleolimnological evidence therefore suggests that Māori arrival within the Lake Nganoke catchment occurred between AD 1417-1551 (95\% confidence interval). Although this is younger than the established date for settlement in New Zealand: AD 1150-1250 (McFadgen, 2003b, 2003a; Wilmshurst et al., 2004; McWethy et al., 2010; McWethy et al., 2013), it agrees with the approximate date of arrival at AD 1450 prescribed in Section 4.2. The location of relatively early radiocarbon samples southeast of Lake Nganoke (Palliser Bay: AD 1350 +/-70)(McFadgen, 2003b, 2003a) and later dates northwest (Lake Pounui: AD 1500 - 1600)(Cochrane, 2017) consequently make a strong case for the progression of Māori inland from Palliser bay to the Wairarapa Valley during this period.

Trodahl et al. (2016a), however, identify an increase in charcoal in Lake Wairarapa at AD 1230 not seen within Lake Nganoke record. This may indicate that Māori settled further inland around Lake Wairarapa prior to the area surrounding Lake Nganoke, contradictory to the hypothesis of progression inland from Palliser bay. Whilst evidence of regional burning (one charcoal sample at $<100 \mu \mathrm{m}$ ) can be seen at AD 1130-1200 within Lake Nganoke, neither local burning, a decline in tall trees, or a growth in grasses, shrubs and bracken fern are observed (for which Trodahl et al. (2016a) have no measurements). Currently, there is no evidence (charcoal <100 microns) in Lake Nganoke for this early landscape disturbance signal. The single sample at AD 1130-1200 is therefore more likely a part of the natural fire regime. 
The validity of chronology within Trodahl et al. (2016a) however must be questioned. Trodahl et al. (2016a) chronology is modelled on one radiocarbon sample of a freshwater mussel, which has the potential to move within lake sediments. Furthermore, in the case where radiocarbon ages from lake sediments have been used to date Polynesian arrival, ages have the potential to be contaminated by old carbon (McGlone \& Wilmshurst, 1999d; Sutton et al., 2008; Striewski et al., 2009). The fact that the date was on a freshwater mussel is particularly problematic, as such radiocarbon targets suffer from local reservoir effects as they fix their carbon from the water column of the lake.

Dating of Polynesian arrival within Lake Wairarapa by Trodahl et al. (2016a) is therefore at best speculative. While uncertainties within Polynesian arrival within Lake Nganoke are rather large (95\%: $\mathrm{AD} 1418$ to 1555 ), the arrival in AD 1250 is observed well outside this. The chronology of Lake Nganoke is developed from a range of dating techniques, and therefore provide a more parsimonious chronology of surrounding landuse change, subsequently providing a superior estimate on Polynesian arrival. Furthermore, Cochrane (2017) found a similar timing of palynological evidence in Lake Pounui identified in Lake Nganoke. Located some $\sim 7 \mathrm{~km}$ west of Lake Wairarapa, the lack of data concerning Polynesian settlement at AD 1230 further questions previous dating of Polynesian arrival within Lake Wairarapa.

\subsubsection{RESPONSE OF LAKE ECOSYSTEM AND QUALITY CHANGE}

Following Polynesian arrival $\sim \mathrm{AD} 1450$, Lake Nganoke's ecosystem and water quality is characterised by a relatively stable bacterial taxonomic composition and a decline in algae productivity within the lake. The NMDS plots for changes in bacterial taxa composition indicates a continuous change in taxa composition across the pre-human and Māori boundary. A clear overlap between the zone boundaries implies that taxonomic composition during this timeframe could simply be a record of gradual environmental shifts. More likely however, the two oldest pre-human samples overlap within the Māori zone and could therefore be a simple issue of sampling resolution. A higher resolution throughout this period would address this.

While increases of sedimentation and in-lake productivity post Polynesian land clearance are expected (McGlone, 1989a; McGlone \& Wilmshurst, 1999a), the opposite is observed within Lake Nganoke. Riparian planting by Māori may explain both the decline in sedimentation rate and in-lake productivity decline 
Cyperaceae and Typha growth on the fringes of the lake post-Māori arrival (AD 1450) is likely a local response to either increased light availability at the lake's margins due to forest removal and/or intentional planting as these taxa were used by Māori. Increased plantings in lake marginal taxa limit both sediment and nutrient inputs and in turn reduce productivity. Furthermore, restrictions in nutrients entering the waterways limits algae growth and consequently the productivity of benthic organisms (Carey \& Migliaccio, 2009). Additional evidence is highlighted in AD 1450 - 1550 with a clear decrease in lake productivity at the same time as terrigenous organic material and sedimentation decreases within the lake. Restrictions in the temporal resolution of $\mathrm{TN}$, residual $\mathrm{P}$ and $\mathrm{C}: \mathrm{N}$ ratios samples restrict understandings of nutrient loading pre Māori arrival ( AD 1450), limiting an informed understanding of water quality and ecosystem change post Māori arrival.

The question arises as to why marginal lake plants such as Typha and Cyperaceae increase in abundance post land clearance AD 1450. Two potential explanations exist: clearing trees from the lake edge allows more light to reach the lake, consequently promoting these plants to grow and become established, and second these taxa have cultural value to Māori, and as a result, are intentionally cultivated. The pollen record suggest that tall trees decline in the Lake Nganoke post AD 1450, which could increase light availability for the growth of lake marginal plants. However, an increase in light availability would also increase within lake productivity, which does not occur in the Lake Nganoke record. Lake marginal taxa growth is therefore probably largely driven through cultivated planting by Māori, with increased light as a result of forest clearance playing a minor role in promoting plant growth.

Further evidence for Māori planting post settlement AD 1450, is observed through indicator taxon Atribacteria remaining relatively stable. Consisting of strictly anaerobic taxa (Frank et al., 2016; Liu et al., 2019), although nitrogen fixing Thermodesulfobrionia are non-photosynthetic organisms. Therefore, an increase in this taxon is unlikely the result of changes in the tree canopy surrounding the lake, but rather evidence of atmospheric nitrogen fixation. The lack in change of other indicator taxa, like Deltaproteobacteria and Atribacteria, combined with productivity (hyperspectral and residual P) further suggests that external nutrient loading within this zone is relatively low and constant, the result of nitrifying bacteria providing a small nursery effect for nutrient dependant taxa. Declines in lake productivity (hyperspectral) are therefore more 
likely the result of decreases in nutrient rich sediment entering lake Nganoke; further supporting the hypothesis of buffering provided by the growth of marginal vegetative taxa.

The ecosystem within lake Nganoke during the Māori zone is therefore likely driven by a combination of in-lake nutrient cycling, with small increases in external nutrients post AD 1550. Decreases in sedimentation directly post settlement are likely the result of increases in marginal lake plant taxa, while low levels of algae productivity indicate healthier water quality levels than recorded during the pre-human era. This suggests that apart from the initial impact of land clearance, Māori intentionally or unintentionally "managed" nutrient loads entering the lake relatively well.

\subsection{EUROPEAN: AD 1850-1950}

\subsubsection{LANDUSE}

Peaks in Pinus abundance and further declines in Pteridum and Cyperaceae occur in the early to mid $19^{\text {th }}$ century and are consistent with European land clearance shortly after settlement in New Zealand AD 1840 (Elliot et al., 1998; Elliot, 1998; McGlone \& Wilmshurst, 1999b; Horrocks et al., 2007). Historical evidence of European arrival within the Wairarapa region is well documented, consisting of first arrival at Palliser Bay in AD 1770, sheep farming production in AD 1844 and regional settlement of the Wairarapa Valley by AD 1853 (Hill, 1963b; Leach \& Anderson, 1974). Considered a strong indicator for European arrival (Byrami et al., 2002; Ogden et al., 2006; Abrahim et al., 2013), Pinus is first observed within Lake Nganoke at AD 1846. However, due to the resolution of pollen chronology, the exact introduction of the taxon cannot be constrained further than post AD 1841 (95\% CI: 1700-1932).

Surprisingly, macroscopic charcoal flux $>100 \mu \mathrm{m}$ diminishes rapidly following European arrival, indicating low amounts of land clearance by fire. Regionally, charcoal influxes $<100 \mu \mathrm{m}$ show less of a reduction, likely influenced by a low sampling resolution in the palynology over the Māori to European transition which precludes any ability to draw conclusions about exactly when the last phase of deforestation occurred. Despite this limitation, further evidence of European arrival on the regional landscape is observed in additional changes in vegetation post $\sim$ AD 1850. Declines in Fuscospora are likely further evidence of deforestation for agriculture. Increases in Poaceae (made up of both native and exotic species) and exotic pollen Rumex and acetosella are suggestive of land 
clearance for cultivated pastoral development and most probably regional (Kissling et al., 2005). With this in mind, it is estimated that while first European settlement occurred $\sim$ AD 1840, large scale European arrival is slightly later at approximately AD 1850 (95\% CI: AD 1809-1870), which fits with the date of regional settlement prescribed from the literature (Cochrane, 2017; Waters, 2018).

Previously identified as a major problem associated with anthropogenic landuse change, land clearance destabilises the catchment, increasing erosion. Moreover, excess available nutrients can be found within the surrounding soils as they are not absorbed by diminishing vegetation (Fahey \& Jackson, 1997). The effect is even greater when extra nutrients are added to the soil via animal effluent and fertiliser additions (Harper et al., 1993). Well documented, excess nutrients in the water body can cause eutrophication and internal nutrient loading, consequently degrading lake health (Canfield Jr \& Hoyer, 1988; Correll, 1998; Smith et al., 1999; Smith \& Schindler, 2009).

Reconstructions of agricultural stock around Lake Nganoke detect external nutrient loading post AD 1900 and again in AD 1940 via ruminant gut flora. While increases in stocking rates within the European zone are consistent with historical records for the Wairarapa region (for further information see Chapter 2, Section 2.2), declines are not (Anastasiadis \& Kerr, 2013a). An explanation for fluctuations in stocking rate (ruminant gut flora) not matching historical stocking increases involves the taphonomy of faecal material. While faecal material traveling vast distances through a watercourse is well documented (Oliver et al., 2005), the resultant concentration deposited in a sedimentary basin is poorly understood (Vogel et al., 2007). Increases in ruminant detection are therefore most likely a local signal of stock that have come into direct contact with the lake edge or body. A comprehensive history of the catchments stocking rate would provide a separate chronology, and potentially a check on the validity of ddPCR as a proxy for stocking rates.

Levels of cadmium within Lake Nganoke sediments increase post arrival in AD 1850, remaining stable from AD 1890 to 1948. Another form of agricultural nutrient fertilisation, elevated concentrations of cadmium as a result of excess superphosphate application is well documented within New Zealand (Bramley, 1990; Ma \& Rao, 1997; Taylor et al., 2017). Superphosphate was not imported into New Zealand until AD 1867 and national manufacturing only commenced in $\mathrm{AD} 1881$, which seems at odds with the 
increase in cadmium from $\mathrm{AD}$ 1850. However, when considering uncertainty in the chronology, the first increase of cadmium overlaps with the date of importation. Furthermore, low levels of cadmium pre AD 1950s are likely the result of fertilisation accessibility restricted to flatter areas. Early increases in cadmium levels post European arrival are likely the result of first superphosphate fertilisation in and around the lowlying areas of Lake Nganoke's catchment. Similar to the application of ruminant faecal DNA as a proxy for stocking rates, further validation of cadmium could be examined with a thorough history of fertilisation within the lake's catchment.

\subsubsection{RESPONSE OF LAKE ECOSYSTEM AND QUALITY CHANGE TO DRIVERS OF LANDUSE CHANGE}

Increases in lake productivity are often linked to increased fertilisation and stocking rates (Burns, 1991; Abell et al., 2010; Finlay et al., 2013; Nielsen et al., 2014). Rising levels of cadmium suggest increasing rates of fertilisation and higher nutrient loads entering Lake Nganoke post AD 1850. Furthermore, fertilisation levels correlate with increases in algae productivity and Res $\mathrm{P}$, suggestive of a close relationship throughout the entirety of the European zone. Lake Nganoke algal productivity within the European zone is therefore likely driven by the advent of increased agricultural landuse post-European settlement.

Within Lake Nganoke dramatic increases of the macrophyte Potamogeton can also be observed post European arrival. Two explanations arise for the appearance of the taxon: first, increased nutrients drive in-lake productivity, promoting macrophyte growth; and second, increased water clarity promotes suitable habitat for the taxon. While there is no evidence for increased water clarity (such as decreases in bloom-forming bacteria), highly productive lakes tend to have increased phytoplankton growth consequently blocking light from reaching lake macrophytes (Kane et al., 2014). Although improved water clarity cannot be ruled out, it is more likely that Potamogeton growth within Lake Nganoke is the result of agricultural nutrient loading and therefore supports the argument for nutrient driven in-lake productivity.

Clear changes in bacterial taxonomic composition (NMDS axis 1) are highlighted at the start of European arrival in $\sim \mathrm{AD} 1850$, followed by a period of stability from AD 1880 to $\mathrm{AD} 1940$. The trend in bacterial composition correlates well with $\mathrm{Cd}$ concentrations, providing a strong argument for a link between fertilisation rates, lake productivity and 
bacterial community change. Further evidence of Lake Nganoke's response to European landuse can be observed through increases of indicator taxa Gammaproteobacteria and decreases in Atribacteria. Known denitrifying bacteria, Gammaproteobacteria respond to increases in bioavailable nutrients entering a water body. This response provides strong evidence of the lake ecosystem responding to changes in nutrient flux because increased nutrient loading within Lake Nganoke has already been demonstrated through proxies such as cadmium.

Furthermore, bacterial taxa observed at $\sim$ AD 1865 indicate similar configuration to those found within the intensification zone suggesting a brief phase of degraded water quality that the system recovered from. Interestingly, both minor peak in productivity and the end of the increase in Cd correlate to this taxonomic change. This is the first time indicator bloom-forming Oxyphotobacteria are observed within Lake Nganoke. Consequently, it is speculated that initial fertilisation pushed the lake towards a more eutrophic state from which it recovered when the fertilisation rate plateaued.

Atribacteria live in anaerobic environments, typically indicative of a highly productive ecosystem promoting algae growth (Nobu et al., 2016). Diminishing levels of Atribacteria therefore likely represent increasing oxygen within Lake Nganoke, contrary to the low oxygen levels associated with high algal productivity. Two reasons as to why are speculated: first, nitrogen-fixing taxa could encourage oxygen-dependant taxa through oxidised nitrification; and second Lake Nganoke's water column is easily mixed. Given that Lake Nganoke is relatively shallow ( $>2 \mathrm{~m}$ ), its water column would be easily mixed by wind-generated waves on the lake surface. The final clearance of lake marginal trees during European settlement would only have promoted this process.

Increases in productivity and changing taxa composition is opposite to the that found within Māori and pre-human zones. Anthropogenic forcing within the European zone is therefore identified as having far more of an impact on the productivity and composition of organisms within Lake Nganoke than Māori and pre-human zones. This is likely the result of the agricultural landuse and increased nutrient fluxes into the lake.

\subsection{INTENSIFICATION: AD 1950 - 2019}

\subsubsection{LANDUSE}

The intensification period within Lake Nganoke is characterised by further increases 
in Pinus, a peak of Salix at AD 2000 and little to no changes of Poaceae (native and exotic grasses). Periods of burning indicated through charcoal abundance are observed to drop post AD 1950, remaining relatively low. This suggests that the majority of land within Lake Nganoke's catchment has already been cleared for agricultural purposes with any increases in excess nutrient loads likely not the result of deforestation or land clearance. Increases in sediment $\mathrm{Cd}$ are indicative of both increased superphosphate application rates in the Lake Nganoke catchment. These increases are consistent with trends in fertilizer application in the wider Wairarapa and New Zealand more generally (Wendelken, 1976; Vant \& Huser, 2000; MacLeod \& Moller, 2006b; Moller et al., 2008; Anastasiadis \& Kerr, 2013b).

Industry driven reductions in cadmium concentrations in AD 1997 potentially provide an independent way of assessing the validity of cadmium as a proxy for fertilisation. At this time the source of superphosphate was changed from cadmium rich Nauru to Western Saharan that has lower cadmium concentrations. Cadmium levels within Lake Nganoke decline in AD 1999 (95\% CI: 1992 - 2013), which correlates well with the change in superphosphate source. The correlation may suggest that cadmium is a reliable proxy for reconstructing historical fertilisation. While this decrease could be representative of fertilisation decreases at a local scale, the timing and size make it more likely to be representative of changes in cadmium abundance. Large increases of cadmium in the surface sediment could be evidence of a degradation signal, as values begin to rise contrary to the evidence of stabilising fertilisation use post AD 2000.

Further evidence of excess nutrients as a result of agricultural intensification are highlighted through increases in ruminant gut flora post AD 1950. Detections of ruminant faecal DNA within Lake Nganoke are consistent with records of increasing stocking rates post AD 1950 (Awarua-o-Porirua, 2018; Drewry et al., 2019). Numbers of stock within New Zealand is generally recognised as rapidly increasing post AD 1950 (Winder, 2009). While ddPCR and independent evidence are consistent with one another, further work that compares the DNA proxy with actually local stocking rates are required before conclusions about the robustness of the proxy can be drawn. Escalating numbers within the catchment are therefore more likely representative of over-saturation within the catchment, accounting for low levels identified pre $\sim \mathrm{AD} 1950$. This indicates there is probably some threshold stocking rate above which the proxy becomes reliable. 
Therefore, the general consensus and evidence provided by this reconstruction aligns with the theory of increased stocking and fertilisation rates as the main cause of lake ecosystem and water quality degradation (Abell, Hamilton, et al., 2011; Dymond et al., 2013; Nielsen et al., 2014).

\subsubsection{RESPONSE OF LAKE ECOSYSTEM AND QUALITY CHANGE TO DRIVERS OF LANDUSE CHANGE}

Cadmium (a proxy for superphosphate fertilisation) and ruminant faecal DNA follow a comparable trend to that of lake productivity, residual phosphorous, and bacterial community composition (NMDS). The importance of fertilisation as a driver for lake ecosystem and water quality change becomes apparent, as increases in external loading (fertilisation) can directly be linked to the growth of in-lake algae and subsequently productivity (Dodson et al., 2000; Salmaso, 2010; Norton et al., 2012; Thackeray et al., 2013). Furthermore, increased productivity has increased bioavailable $\mathrm{P}$ in the surface sediments and initiated a positive feedback that is driving the lake towards a more eutrophic state (Woodward, 2013).

Thriving in anaerobic conditions, the decline of Atribacteria to undetectable levels post AD 1950 further supports increasing oxygen within the water column. This is reinforced by ASVs of denitrifying Gammaproteobacteria increasing dramatically at the start of the zone before plateauing. Surges in the abundance of bloom forming Cyanobacteria along with increases in the productivity is an unequivocal indication of decreased water quality (Ministry for the Environment, 2014). Furthermore, observations of Oxyphotobacteria, a denitrifying bloom-forming cyanobacteria, increase substantially post AD 1950 before decreasing post AD 1990. Interestingly, both Potamogeton and Oxyphotobacteria peaks match nicely with stocking rates inferred from ruminant DNA (AD 1960). Potentially, this supports the argument that increased fertilizer application and stocking rates have amplified nutrient loading in the lake, with nutrient loading resulting in a wholescale shift in the ecosystem. The implication is that without immediate action, Lake Nganoke may continue to degrade into the future.

Declines of cyanobacteria abundance post AD 2000, however, indicate potential improvements in the degradation of lake quality. Issues, therefore, arise over the status of lake health over the last 20 years. High levels of lake productivity indicate further degradation to eutrophic conditions, yet Cyanobacteria which thrive in these conditions 
decreases. Additionally, nitrogen-fixing taxa Thermodesulfobrionia increase post AD 1950 despite increases in external nutrient fluxes. Further studies into known water quality markers such as chironomids or diatoms could potentially shed some light on this puzzling phenomenon.

\subsection{ASSESSMENT OF THE EFFECTIVENESS OF RIPARIAN ZONES IN MITIGATING AGRICULTURALLY RICH NUTRIENTS}

While the documentation of riparian zones is well investigated within literature (Ilhardt et al., 2000; Gold et al., 2001; Johansen \& Phinn, 2006), factors influencing their ability to mitigate agricultural nutrients is often a point of contention (Rabeni \& Smale, 1995; Thenya et al., 2006; Wondie, 2010). Furthermore, the ever changing composition of riparian zones makes understandings of buffering nutrients complex as a wide range of factors play a role in influencing the success in mitigating the negative effects of excess agricultural nutrients entering water bodies (Sabo et al., 2005). Riparian classification of Lake Nganoke through aerial images is therefore a rather simplistic assessment of riparian buffering, providing little understandings of the dynamics concerning taxa composition (Rowlinson et al., 1999; Baker et al., 2006; Johansen et al., 2010). Assessing the growth and maturity of Lake Nganoke's riparian are consequently limited to a presence or absence based approach, with maturity established by a lack of change over the remaining imagery. None the less, the aerial photo record allows to map change in the riparian zone both around the lake and in the catchment over decadal timescales. This is an unrivalled perspective.

\subsubsection{THE EFFECTIVENESS OF RIPARIAN GROWTH IN MITIGATING AGRICULTURALLY RICH NUTRIENTS WITHIN LAKE NGANOKE:}

Riparian growth within Lake Nganoke is observed to have no impact on the trajectory of lake water quality or ecosystem change. Dramatic increases in fertilisation $(\mathrm{Cd})$ and inlake productivity ( $\mathrm{Chl}$ a) are associated with rapid changes in the bacterial community composition (MDS axis 1) between AD 1950 and 1970. The riparian zone reaches it maximum aerial extent in $\sim$ AD 1961, with both the average stream (30 m) and lake marginal $(5 \mathrm{~m})$ riparian width remaining constant from $\sim \mathrm{AD}$ 1970. Lake Nganoke experiences an ongoing eutrophication trend, despite riparian reaching its maximum extent and remaining constant from $\sim$ AD 1961.. Therefore, the alternate hypothesis outlined in Section 3.1 is rejected. 
While riparian zones within Lake Nganoke have not been found to be an effective buffer of agriculturally rich nutrients, multiple studies concerning fresh water lake degradation indicate otherwise (Choi, 1970; Addiscott, 1996; George, 2009). Timescales over which these studies occur, however, are extremely small covering no more than 3-5 years of monitoring. As highlighted by variations in lake ecosystem and productivity within Lake Nganoke, changes within lake systems can take decades if not longer to manifest, with the effects of agricultural nutrients not always immediate within resilient lakes. As such, further research is needed to investigate the lag times in responses to riparian mitigation. The result implies that conventional monitoring studies that only represent a short snapshot of time may not be representative of long term trends. The paleo record within this thesis does however capture the full time frame of riparian growth and maturity, providing a temporal extent far beyond current monitoring methods.

One potential explanation for the poor performance of riparian planting at Lake Nganoke's the narrow extent of the lake marginal riparian (less than $5 \mathrm{~m}$ in some places with a maximum of $15 \mathrm{~m}$ ). Dodson et al. (2005) highlight changes in 73 small and shallow lakes within Wisconsin, USA, finding that agricultural sites with wide riparian buffer strips greater than $30 \mathrm{~m}$ had significantly healthier lake ecosystems than those with narrower strips. Aguiar Jr et al. (2015) highlight a minimum width of $36 \mathrm{~m}$ as successful in reducing agriculturally rich diffuse source contaminants entering rivers. They measured a range of widths from 12 to $60 \mathrm{~m}$. Within New Zealand, investigations into riparian effectiveness are almost all exclusively river focused, with Baillie and Neary (2015) finding $42 \%$ of buffer zones were $>5-2 \mathrm{~m}$ wide in a degrading stream while Greenwood et al. (2012) identified $62 \%$ as $5 \mathrm{~m}$ or less. This is consistent with findings by Parkyn et al. (2000) who suggested that areas of planting less than $5 \mathrm{~m}$ wide are not likely to mitigate agriculturally rich landuse.

Generally, the wider the planting the greater the filtration ability (Fennessy \& Cronk, 1997), and although the minimum width is often a point of contention, $30 \mathrm{~m}$ is commonly referred to. Reasons for this primarily include the difficulty in discerning the distinction between the riparian zone and the adjacent landscape, for which each case is site dependant (Hansen et al., 2010). In the case of Lake Nganoke, the stream marginal riparian width likely meets best practice specifications $(>30 \mathrm{~m})$ while the small part of lake marginal riparian does not. The insufficient buffer width seen within the lake margin is therefore likely the main contributing factor in the increased water degradation 
experienced within Lake Nganoke. The nature of Lake Nganoke's data suggests the importance of continuous minimum width standards for riparian planting because a minimum of the recommended width seems to have had an impact while the recent smaller riparian has not.

Riparian mitigation of terrestrial nutrient fluxes appeared to function much more effectively during the Māori zone compared to the European and intensification zones. Evidence of riparian mitigation following Māori settlement is observed through increases of marginal wetland taxa Typha being co-temporal with a decrease is lake productivity and sedimentation rate. Furthermore, decreases in abundances of Cyperaceae and Typha post European arrival imply a reduction in riparian composition, while increases in Potamogeton as lakebed dwelling macrophytes are unlikely to provide nutrient mitigation functions. Although riparian established during the Māori zone is observed to buffer nutrient run-off from the subsistence cultivation, riparian buffering capabilities post European settlement cannot cope with the combined agriculture/intensification and apparent decrease in riparian size. This further supports the hypothesis of riparian planting during the European and intensification zone being insufficient in size to capture and mitigate nutrient rich run-off.

Evidence of increased lake quality during Māori landuse is not restricted to this thesis alone, with a recent publication by Cochrane (2017) providing further support of the buffering capabilities observed. The pollen record from Lake Pounui in the Wairarapa indicated that the aquatic plant Isoetes increases when Māori settled the area. Isoetes is an indicator for high water clarity and hence good water quality (Clayton \& Edwards, 2006). Further investigation into the success of riparian planting during Māori settlement and the taxa involved using a network of pollen records from shallow lowland lakes could potentially shed some light into the use for future mitigation schemes.

\subsection{VALIDITY OF PALEO-BASED METHODS}

Generally speaking, a higher sampling resolution creates a more robust reconstruction. Time and funding, however, plays a huge role in defining sampling resolution and number of proxies. This thesis was fortunate enough to be supported by the Lakes380 project, able to draw on a wide range of skills and resources, reducing time as well as costs. Higher resolution radiocarbon and lead ${ }^{210}$ dating would create a more robust age-depth model. Furthermore, additional sampling of all proxies at a greater resolution during key 
identified areas (Māori/European and the prehuman/Māori transition) would provide greater insight. A greater suite of proxies such as diatom and chironomid analysis would have complemented findings providing supplementary evidence. These proxies should form the basis of any further work.

While indicators of landuse change are investigated within lake sediments, little to no research has been conducted on the identification and quantification of agriculturally intensified landuse (Gaillard et al., 1992; Enters et al., 2008; Yang, Anderson, et al., 2008; McWethy et al., 2010). Quantitative measures of agricultural intensification derived from lake records could provide insights into the complex relationships between excess nutrient loading and declining water health within New Zealand.

The proxy ddPCR provides a quantitative amplification of ruminant gut flora simply not possible through traditional techniques. While some studies have reported an increased sensitivity of the ddPCR to detect low quantities of target DNA (Strain et al., 2013; Sze et al., 2014; Doi et al., 2015), little to low readings of ruminant DNA were found in timeframes where stocking rates were known to increase (AD 1850 - 1950). As the majority of these studies were conducted from aquatic water samples, sediment may play a different role in storing target DNA. This raises the concept of ruminant detection within sediment relying heavily on localised stock access (Giguet-Covex et al., 2019), with readings requiring high saturation in order to increase amplifications of DNA. Furthermore, the rapid increase post AD 2000 could be indicative of a degradation signal as the DNA breaks down throughout the core. Further research is required to assess whether direct livestock interaction with the lake or thresholds for detection drive the stocking signal within sediments derived from ruminant faecal DNA This validation is crucial before the proxy is used more widely within literature.

Concerning lake sediments, cadmium is primarily analysed for the purpose of heavy metal contamination (Sander et al., 2013), with little thought to the use as a proxy for fertilisation rates. Further authentication of cadmium was corroborated with known declines in nationwide cadmium within superphosphate, both as a result of changing the rock origin and industry reductions. It was concluded that cadmium levels within sediment cores of Lake Nganoke were a fairly accurate representation of fertilisation rates within the catchment. Further research into the movement of cadmium from soil to lake sediments would provide a greater understanding of the pathway process. 
While total concentrations of phosphorus in sediments are limited in predicting ecological responses to nutrient loading, fractions of phosphorus provide an integral insight into internal nutrient cycling (Kleeberg \& Dudel, 1997; House \& Denison, 2000; Thirunavukkarasu et al., 2000). Although this thesis predominantly focused on fractions of residual phosphorous, other forms such as reductant $\mathrm{P}$ and metal bound $\mathrm{P}$ potentially provide further insight into the complex dynamics of phosphorus loading within lakes. Caution, however, must be taken when these forms as they are known to be more mobile throughout sediment cores, and as such may not provide accurate measurements.

Within the context of Lake Nganoke, readings of residual phosphorous replicate similar trends to that of lake productivity (RABD 660-670 nm). Unsurprisingly, productivity correlates nicely with residual $\mathrm{P}$ and therefore provides a useful validation of the productivity signal. This relationship also has the potential to provide useful insights into internal nutrient cycling. 


\section{CHAPTER 8: CONCLUSION}

With increasing pressure to improve national water quality, it is vital to have informed understandings concerning the components of lake ecosystem resilience, drivers of degradation and anthropogenic impact. The use of paleolimnology in evaluating historical landuse, lake quality and ecosystem change, provides a temporal extent simply not possible through conventional monitoring techniques. To investigate the response of lake quality and ecosystem response to changes in landuse, this study aimed to reconstruct the past environment of Lake Nganoke from a pre-human reference state to current day. Specifically, the role of rising nutrient fluxes as a consequence of agricultural intensification was addressed and the ability of riparian zones to buffer these nutrients examined.

\subsection{RECONSTRUCTION OF HISTORIC LANDUSE AND WATER QAULITY WITHIN LAKE NGANOKE}

To reconstruct the past environment of Lake Nganoke, an age-depth model was created. The model placed the base of the sediment cores at $\sim$ AD 1150 (95\%: AD 769-1366). Human impact on the landscape was documented using charcoal, pollen, environmental DNA and geo-chemical analyses. Based on these proxies, three changes of landuse were identified within Lake Nganoke's catchment, these being Māori arrival AD 1450 (95\% CI: AD 1417-1551), European settlement AD 1850 (95\% CI: 1809 - 1870) and agricultural intensification $\sim$ AD 1950 (95\% CI: 1948 - 1964).

Lake Nganoke's water quality and ecosystem pre AD 1450 is presumably a shallow environment with a constant catchment input of natural nutrients and dominated by tall trees and likely heavily forested. Lake algal productivity during this zone is defined as average, while bacterial composition similarly shows little to no change. Large abundances in Atribacteria indicate Lake Nganoke as anoxic, with lake marginal vegetation limiting wind mixing, promoting lake stratification. A likely explanation for high rates of algal productivity is high bird numbers providing an alternative nutrient source within the lake.

As a result of land clearance for subsistence horticulture, tall trees within Lake Nganoke's catchment diminish post Māori arrival $\sim \mathrm{AD}$ 1450. Algal productivity significantly decreases post settlement, most likely the result of increased lake marginal taxa buffering nutrient rich sediment from entering the water column. This is further supported by no 
change in anoxic thriving Atribacteria. Apart from the initial impact of land clearance and further evidence of burning at AD 1700, Māori "managed" nutrients entering the lake relatively well, with changes in productivity indicating improvements to Lake Nganoke's water quality post AD 1450. The healthier water quality and ecosystem during this period is thought to be the result of purposeful lake marginal planting of plant taxa such as Typha.

European arrival AD 1850 was characterised by increases in exotic taxa such as Pinus and Salix, a decline in Pteridium and an increase in fertilisation and stocking rates. Lake Nganoke algal productivity rapidly increases post settlement, likely the result of increased nutrients from further land clearance and increased agriculture. Further evidence of increased nutrients entering the water column are provided through increases of Gammaproteobacteria. The result of nutrients from fertilizer application, in-lake productivity and changes in bacterial composition, Lake Nganoke water quality likely declines post European settlement. Furthermore, a strong relationship between increases in fertilisation rates and lake productivity indicate fertilisation as a strong driver of change.

Agricultural intensification post AD 1950 further increases the amount of agricultural nutrients entering Lake Nganoke's water column. Overall, vegetation changes very little during this period, likely indicative that the majority of Lake Nganoke's catchment had already been converted for agricultural landuse. Increases in fertilisation and stocking rates provide further evidence that increased nutrient run-off as a result of landuse intensification degraded water quality. Algal productivity and bacterial composition continue to change dramatically post AD 1950, likely the result of excess nutrients promoting algal growth. The absence of Atribacteria suggest Lake Nganoke is oxygenated, while constant abundances in Gammaproteobacteria indicate high nutrient loading. Bloom forming Cyanobacteria peak in abundance during this zone, consistent with nutrient loading and direct evidence of a decline in water quality.

Changes in Lake Nganoke water quality and ecosystem from pre-human reference states to agriculturally intensified landuse is obvious in the Lake Nganoke record. The alternate hypothesis is accepted. 
"Anthropogenic landuse intensification in the Lake Nganoke catchment has resulted in ecosystem change and a stepwise decrease in water quality from a prehuman baseline, through Māori subsistence, European agricultural and intensification"

While water quality does decrease from pre-human states, the decline is not immediate, largely starting from European arrival. Furthermore, water quality is observed to improve post Māori settlement, likely the result of lake marginal planting. This indicates European landuse and intensification as potentially having a greater impact on water quality within Lake Nganoke.

\subsection{THE ABILITY OF RIPARIAN ZONES TO BUFFER NUTRIENT RICH AGRICULTURAL RUN-OFF}

A degradation is observed in Lake Nganoke water quality post riparian growth and maturity, likely the result of an insufficient buffer width. The alternate hypothesis is therefore rejected.

"The planting of a riparian zone around the lake has buffered lake water quality against intensification of agriculture"

The absence of robust assessment in riparian composition however makes other factors (such as nutrient flow paths, retention rates and taxa composition) a possible reason for riparian failure. A more in-depth assessment of the riparian zone within Lake Nganoke's catchment would address this.

Regardless, the information gained through paleolimnological analysis of Lake Nganoke's sediment has provided a better understanding of the natural lake environment. This information will enable more informed decisions on restoration targets and the future use of paleo proxies in reconstructing agricultural drivers of lake water quality and ecosystem change. It is recommended that lake ecosystem and water quality targets within Lake Nganoke be centred towards the low rates of algal productivity and sedimentation observed during Māori landuse. Finally, it is concluded that present riparian planting is insufficient to cope with nutrient loading from the current stocking and fertilisation regime. 


\section{REFERENCES}

A.K. Booth, H. S. G. (1969). SOILS AND FARMING PATTERNS IN THE WAIRARAPA. Retrieved from

Abell, J. M., Hamilton, D. P., \& Paterson, J. (2011). Reducing the external environmental costs of pastoral farming in New Zealand: experiences from the Te Arawa lakes, Rotorua. Australasian Journal of Environmental Management, 18(3), 139-154.

Abell, J. M., Özkundakci, D., \& Hamilton, D. P. (2010). Nitrogen and phosphorus limitation of phytoplankton growth in New Zealand lakes: implications for eutrophication control. Ecosystems, 13(7), 966-977.

Abell, J. M., Özkundakci, D., Hamilton, D. P., \& Miller, S. D. (2011). Relationships between land use and nitrogen and phosphorus in New Zealand lakes. Marine and Freshwater Research, 62(2), 162-175.

Abrahim, G. M., Parker, R. J., \& Horrocks, M. (2013). Pollen core assemblages as indicator of Polynesian and European impact on the vegetation cover of Auckland Isthmus catchment, New Zealand. Estuarine, Coastal and Shelf Science, 131, 162-170.

Addiscott, T. (1996). A critical review of the value of buffer zone environments as a pollution control tool. Paper presented at the Buffer zones: their processes and potential in water protection. Proceedings of the International Conference on Buffer Zones.

Aguiar Jr, T. R., Rasera, K., Parron, L. M., Brito, A. G., \& Ferreira, M. T. (2015). Nutrient removal effectiveness by riparian buffer zones in rural temperate watersheds: The impact of no-till crops practices. Agricultural Water Management, 149, 74-80. doi:https://doi.org/10.1016/j.agwat.2014.10.031

Anastasiadis, S., \& Kerr, S. (2013a). Land use and farming intensity: For 1996, 2008 and 2020. Motu Economic and Public Policy Research Report for the Parliamentary Commissioner for the Environment. Available online at http://www. pce. parliament. nz/assets/Uploads/Land-Use-and-FarmingIntensity. pdf.

Anastasiadis, S., \& Kerr, S. (2013b). Mitigation and heterogeneity in management practices on New Zealand dairy farms. Motu Economic and Public Policy Research, Motu Working Paper, 13-11.

Anbumozhi, V., Radhakrishnan, J., \& Yamaji, E. (2005). Impact of riparian buffer zones on water quality and associated management considerations. Ecological Engineering, 24(5), 517-523. doi:https://doi.org/10.1016/j.ecoleng.2004.01.007

Anderson, A. (1991). The chronology of colonization in New Zealand. Antiquity, 65(249), 767-795. doi:10.1017/S0003598X00080510

Aotearoa, L. A. W. (2019). Lake Wairarapa. Retrieved from https://www.lawa.org.nz/explore-data/wellington-region/lakes/lake-wairarapa/

Appleby, P. (2008). Three decades of dating recent sediments by fallout radionuclides: a review. The Holocene, 18(1), 83-93.

Appleby, P., \& Oldfield, F. (1978a). The calculation of lead-210 dates assuming a constant rate of supply of unsupported $210 \mathrm{~Pb}$ to the sediment. CATENA, 5(1), 18.

Appleby, P. G., \& Oldfield, F. (1978b). The calculation of lead-210 dates assuming a constant rate of supply of unsupported $210 \mathrm{~Pb}$ to the sediment. CATENA, 5(1), 18. doi:https://doi.org/10.1016/S0341-8162(78)80002-2

Arnaud, F., Magand, O., Chapron, E., Bertrand, S., Boës, X., Charlet, F., \& Mélières, M.-A. (2006). Radionuclide dating (210Pb, 137Cs, 241Am) of recent lake 
sediments in a highly active geodynamic setting (Lakes Puyehue and IcalmaChilean Lake District). Science of The Total Environment, 366(2-3), 837-850.

Augustinus, P., Cochran, U., Kattel, G., D’Costa, D., \& Shane, P. (2012). Late

Quaternary paleolimnology of Onepoto maar, Auckland, New Zealand: implications for the drivers of regional paleoclimate. Quaternary International, 253, 18-31.

Augustinus, P., Reid, M., Andersson, S., Deng, Y., \& Horrocks, M. (2006). Biological and geochemical record of anthropogenic impacts in recent sediments from Lake Pupuke, Auckland City, New Zealand. Journal of Paleolimnology, 35(4), 789805.

Awarua-o-Porirua, T. (2018). Collaborative Modelling Project-Work Brief 11 RM.

Baillie, B. R., \& Neary, D. G. (2015). Water quality in New Zealand's planted forests: a review. New Zealand Journal of Forestry Science, 45(1), 7.

Baker, C., Lawrence, R., Montagne, C., \& Patten, D. (2006). Mapping wetlands and riparian areas using Landsat ETM+ imagery and decision-tree-based models. Wetlands, 26(2), 465.

Barmuta, L. (2001). New Zealand stream invertebrates: ecology and implications for management. Journal of the North American Benthological Society, 20(3), 502503. doi: $10.2307 / 1468045$

Bartram, J., Ballance, R., \& Organization, W. H. (1996). Water quality monitoring: a practical guide to the design and implementation of freshwater quality studies and monitoring programs.

Battarbee, R. W. (1999). The importance of palaeolimnology to lake restoration. In The Ecological Bases for Lake and Reservoir Management (pp. 149-159): Springer.

Battarbee, r. W., Anderson, n. J., Bennion, h., \& Simpson, g. L. (2012). Combining limnological and palaeolimnological data to disentangle the effects of nutrient pollution and climate change on lake ecosystems: problems and potential. Freshwater biology, 57(10), 2091-2106. doi:10.1111/j.1365-2427.2012.02860.x

Begg, J., Mazengarb, C., \& Mazengarb, C. (1996). Geology of the Wellington area.

Bennion, H., \& Battarbee, R. (2007). The European Union water framework directive: opportunities for palaeolimnology. Journal of Paleolimnology, 38(2), 285-295.

Bennion, H., Battarbee, R. W., Sayer, C. D., Simpson, G. L., \& Davidson, T. A. (2011). Defining reference conditions and restoration targets for lake ecosystems using palaeolimnology: a synthesis. Journal of Paleolimnology, 45(4), 533-544. doi:10.1007/s 10933-010-9419-3

Biggs, R., Schlüter, M., Biggs, D., Bohensky, E. L., BurnSilver, S., Cundill, G., . . . Kotschy, K. (2012). Toward principles for enhancing the resilience of ecosystem services. Annual review of environment and resources, 37, 421-448.

Birks, H. H., Whiteside, M., Stark, D. M., \& Bright, R. (1976). Recent paleolimnology of three lakes in northwestern Minnesota. Quaternary Research, 6(2), 249-272.

Bjerring, R., Becares, E., Declerck, S., Gross, E. M., HANSSON, L. A., Kairesalo, T., . . . CONDE-PORCUNA, J. M. (2009). Subfossil Cladocera in relation to contemporary environmental variables in 54 Pan-European lakes. Freshwater biology, 54(11), 2401-2417.

Björck, S., \& Wohlfarth, B. (2002). 14 C chronostratigraphic techniques in paleolimnology. In Tracking environmental change using lake sediments (pp. 205-245): Springer.

Bofill-Mas, S., Albinana-Gimenez, N., Clemente-Casares, P., Hundesa, A., RodriguezManzano, J., Allard, A., . . Girones, R. (2006). Quantification and stability of human adenoviruses and polyomavirus JCPyV in wastewater matrices. Appl. Environ. Microbiol., 72(12), 7894-7896. 
Bradbury, J. P. (1971). PALEOLIMNOLOGY OF LAKE TEXCOCO, MEXICO. EVIDENCE FROM DIATOMS 1. Limnology and oceanography, 16(2), 180200.

Bramley, R. (1990). cadmium in New Zealand agriculture. New Zealand Journal of Agricultural Research, 33(4), 505-519.

Brodie, J., \& Mitchell, A. (2005). Nutrients in Australian tropical rivers: changes with agricultural development and implications for receiving environments. Marine \& Freshwater Research, 56(3), 279-302. doi:10.1071/MF04081

Broecker, W. S., Lynch-Stieglitz, J., Clark, E., Hajdas, I., \& Bonani, G. (2001). What caused the atmosphere's CO2 content to rise during the last 8000 years? Geochemistry, Geophysics, Geosystems, 2(10).

Bronk Ramsey, C. (2008). RADIOCARBON DATING: REVOLUTIONS IN UNDERSTANDING. Archaeometry, 50(2), 249-275. doi:10.1111/j.14754754.2008.00394.x

Bronk Ramsey, C., \& Lee, S. (2013). Recent and Planned Developments of the Program OxCal. 2013, 11. Retrieved from https://journals.uair.arizona.edu/index.php/radiocarbon/article/view/16215

Brown, G., \& Stone, L. (2007). Cleaner production in New Zealand: taking stock. Journal of Cleaner Production, 15(8), 716-728. doi:10.1016/j.jclepro.2006.06.025

Burger, D. F., Hamilton, D. P., \& Pilditch, C. A. (2008). Modelling the relative importance of internal and external nutrient loads on water column nutrient concentrations and phytoplankton biomass in a shallow polymictic lake. Ecological Modelling, 211(3-4), 411-423.

Burns, Rutherford, J. C., \& Clayton, J. S. (1999a). A Monitoring and Classification System for New Zealand Lakes and Reservoirs. Lake and Reservoir Management, 15(4), 255-271. doi:10.1080/07438149909354122

Burns, C. W. (1991). New Zealand lakes research, 1967-91. New Zealand Journal of Marine and Freshwater Research, 25(4), 359-379. doi:10.1080/00288330.1991.9516491

Burns, N., McIntosh, J., \& Scholes, P. (2005). Strategies for Managing the Lakes of the Rotorua District, New Zealand. Lake and Reservoir Management, 21(1), 61-72. doi:10.1080/07438140509354413

Burns, N., McIntosh, J., \& Scholes, P. (2009). Managing the lakes of the Rotorua District, New Zealand. Lake and Reservoir Management, 25(3), 284-296. doi:10.1080/07438140903083815

Burns, N. M., Rutherford, J. C., \& Clayton, J. S. (1999b). A Monitoring and Classification System for New Zealand Lakes and Reservoirs. Lake and Reservoir Management, 15(4), 255-271. doi:10.1080/07438149909354122

Bussell, M. R. (1988). Mid and late Holocene pollen diagrams and Polynesian deforestation, Wanganui district, New Zealand. New Zealand journal of botany, 26(3), 431-451.

Butz, C., Grosjean, M., Fischer, D., Wunderle, S., Tylmann, W., \& Rein, B. (2015). Hyperspectral imaging spectroscopy: a promising method for the biogeochemical analysis of lake sediments. Journal of Applied Remote Sensing, 9(1), 096031.

Butz, C., Grosjean, M., Goslar, T., \& Tylmann, W. (2017). Hyperspectral imaging of sedimentary bacterial pigments: a 1700-year history of meromixis from varved Lake Jaczno, northeast Poland. Journal of Paleolimnology, 58(1), 57-72.

Byrami, M., Ogden, J., Horrocks, M., Deng, Y., Shane, P., \& Palmer, J. (2002). A palynological study of Polynesian and European effects on vegetation in 
Coromandel, New Zealand, showing the variability between four records from a single swamp. Journal of the Royal Society of New Zealand, 32(3), 507-531.

Canfield Jr, D. E., \& Hoyer, M. V. (1988). The eutrophication of Lake Okeechobee. Lake and Reservoir Management, 4(2), 91-99.

Carey, R. O., \& Migliaccio, K. W. (2009). Contribution of wastewater treatment plant effluents to nutrient dynamics in aquatic systems: a review. Environmental Management, 44(2), 205-217.

Carmichael, W. W., \& Boyer, G. L. (2016). Health impacts from cyanobacteria harmful algae blooms: Implications for the North American Great Lakes. Harmful Algae, 54, 194-212. doi:https://doi.org/10.1016/j.hal.2016.02.002

Catherine, Q., Susanna, W., Isidora, E.-S., Mark, H., Aurelie, V., \& Jean-François, H. (2013). A review of current knowledge on toxic benthic freshwater cyanobacteria-ecology, toxin production and risk management. Water Research, 47(15), 5464-5479.

Chapman, A. S., Foster, I. D. L., Lees, J. A., \& Hodgkinson, R. A. (2005). Sediment delivery from agricultural land to rivers via subsurface drainage. Hydrological Processes, 19(15), 2875-2897. doi:10.1002/hyp.5789

Chardon, W. J., \& Schoumans, O. F. (2007). Soil texture effects on the transport of phosphorus from agricultural land in river deltas of Northern Belgium, The Netherlands and North-West Germany. Soil Use and Management, 23(s1), 1624. doi:10.1111/j.1475-2743.2007.00108.x

Charles, D., Whitehead, D., Engstrom, D., Fry, B., Hites, R., Norton, S., . . Smol, J. (1987). Paleolimnological evidence for recent acidification of Big Moose Lake, Adirondack Mountains, NY (USA). Biogeochemistry, 3(1-3), 267-296.

Chen, S.-H., \& Wu, J.-T. (1999). Paleolimnological environment indicated by the diatom and pollen assemblages in an alpine lake in Taiwan. Journal of Paleolimnology, 22(2), 149-158.

Choi, J. (1970). Establishment and management of riparian buffer zones in Han River basin, Korea. WIT Transactions on Ecology and the Environment, 48.

Chow, L. (2012). A literature review of riparian buffer widths for sediments, nutrients and large woody debris.

Chrapusta, E., Węgrzyn, M., Zabaglo, K., Kaminski, A., Adamski, M., Wietrzyk, P., \& Bialczyk, J. (2015). Microcystins and anatoxin-a in Arctic biocrust cyanobacterial communities. Toxicon, 101, 35-40.

Christophoridis, C., \& Fytianos, K. (2006). Conditions affecting the release of phosphorus from surface lake sediments. Journal of Environmental Quality, 35(4), 1181-1192.

Clayton, J., \& Edwards, T. (2006). LakeSPI - A method for monitoring ecological condition in New Zealand lakes. Retrieved from

Cochrane, L. (2017). Reconstructing Ecological Change, Catchment Disturbance, and Anthropogenic Impact over the last 3000 years at Lake Pounui, Wairarapa, New Zealand.

Cohen, A. S., Palacios-Fest, M. R., Msaky, E. S., Alin, S. R., McKee, B., O’Reilly, C. M., . . . Lezzar, K. E. (2005). Paleolimnological investigations of anthropogenic environmental change in Lake Tanganyika: IX. Summary of paleorecords of environmental change and catchment deforestation at Lake Tanganyika and impacts on the Lake Tanganyika ecosystem. Journal of Paleolimnology, 34(1), 125-145.

Cole, T. L., \& Wood, J. R. (2018). The ancient DNA revolution: the latest era in unearthing New Zealand's faunal history. New Zealand Journal of Zoology, 45(2), 91-120. doi:10.1080/03014223.2017.1376690 
Collier, K., Clapcott, J., \& Neale, M. (2014). A macroinvertebrate attribute to assess ecosystem health for New Zealand waterways for the national objectives framework-Issues and options. Environmental Research Institute report, 36.

Collier, K. J., Cooper, A. B., Davies-Colley, R. J., Rutherford, J. C., Smith, C. M., \& Williamson, R. B. (1995). MANAGING RIPARIAN ZONES:

A contribution to protecting New Zealand's rivers and streams. Retrieved from

Conley, D. J., Paerl, H. W., Howarth, R. W., Boesch, D. F., Seitzinger, S. P., Havens, K. E., . . Likens, G. E. (2009). Controlling eutrophication: nitrogen and phosphorus. In: American Association for the Advancement of Science.

Correll, D. L. (1998). The role of phosphorus in the eutrophication of receiving waters: A review. Journal of Environmental Quality, 27(2), 261-266.

Cramer, M. J., Haghshenas, N., Bagwell, C. E., Matsui, G. Y., \& Lovell, C. R. (2011). Celerinatantimonas diazotrophica gen. nov., sp. nov., a nitrogen-fixing bacterium representing a new family in the Gammaproteobacteria, Celerinatantimonadaceae fam. nov. International journal of systematic and evolutionary microbiology, 61(5), 1053-1060.

Davidson, T. A., \& Jeppesen, E. (2013). The role of palaeolimnology in assessing eutrophication and its impact on lakes. Journal of Paleolimnology, 49(3), 391410.

Davies, S. J., Metcalfe, S. E., Bernal-Brooks, F., Chacon-Torres, A., Farmer, J. G., MacKenzie, A. B., \& Newton, A. J. (2005). Lake sediments record sensitivity of two hydrologically closed upland lakes in Mexico to human impact. AMBIO: A Journal of the Human Environment, 34(6), 470-475.

Davis, C. M., \& Meurk, C. (2001). Protecting and restoring our natural heritage: a practical guide: Department of Conservation.

De Caceres, M., Jansen, F., \& De Caceres, M. M. (2016). Package 'indicspecies'. Relationship between species and groups of sites. $R$ package version, 1(6).

De Cáceres, M., Legendre, P., Wiser, S. K., \& Brotons, L. (2012). Using species combinations in indicator value analyses. Methods in Ecology and Evolution, 3(6), 973-982.

Deng, Y., Ogden, J., Horrocks, M., \& Anderson, S. (2006). Application of palynology to describe vegetation succession in estuarine wetlands on Great Barrier Island, northern New Zealand. Journal of vegetation science, 17(6), 765-782.

Department of Conservation. (2000). Wairarapa Plains Ecological District - Survey report for the Proteced Natural Areas Programme.

Di, H. J., \& Cameron, K. C. (2002). Nitrate leaching in temperate agroecosystems: sources, factors and mitigating strategies. Nutrient Cycling in Agroecosystems, 64(3), 237-256. doi:10.1023/A:1021471531188

Dodson, S. I., Arnott, S. E., \& Cottingham, K. L. (2000). The relationship in lake communities between primary productivity and species richness. Ecology, 81(10), 2662-2679.

Dodson, S. I., Lillie, R. A., \& Will-Wolf, S. (2005). Land use, water chemistry, aquatic vegetation, and zooplankton community structure of shallow lakes. Ecological Applications, 15(4), 1191-1198.

Doi, H., Takahara, T., Minamoto, T., Matsuhashi, S., Uchii, K., \& Yamanaka, H. (2015). Droplet digital polymerase chain reaction (PCR) outperforms real-time PCR in the detection of environmental DNA from an invasive fish species. Environmental science \& technology, 49(9), 5601-5608.

Domaizon, I., Winegardner, A., Capo, E., Gauthier, J., \& Gregory-Eaves, I. (2017). DNA-based methods in paleolimnology: new opportunities for investigating long-term dynamics of lacustrine biodiversity. Journal of Paleolimnology, $58(1), 1-21$. 
Drewry, J., Manderson, A., \& Hedley, C. (2019). Evaluation of irrigation strategies for arable farms to mitigate nitrogen loss using the OVERSEER model. Nutrient loss mitigations for compliance in agriculture. Fertilizer and Lime Research Centre, Massey University. Palmerston North.

Duarte, C. M., Conley, D. J., Carstensen, J., \& Sánchez-Camacho, M. (2009). Return to Neverland: shifting baselines affect eutrophication restoration targets. Estuaries and Coasts, 32(1), 29-36.

Dunnington, D. (2019). Paleolimbot. Retrieved from https://github.com/paleolimbot/pb210

Dymond, J., Ausseil, A.-G., Parfitt, R., Herzig, A., \& McDowell, R. (2013). Nitrate and phosphorus leaching in New Zealand: a national perspective. New Zealand Journal of Agricultural Research, 56(1), 49-59.

Elliot, M., Flenley, J., \& Sutton, D. (1998). A late Holocene pollen record of deforestation and environmental change from the Lake Tauanui catchment, Northland, New Zealand. Journal of Paleolimnology, 19(1), 23-32.

Elliot, M., Striewski, B., Flenley, J., Kirkman, J., \& Sutton, D. (1997). A 4300 year palynological and sedimentological record of environmental change and human impact from Wharau Road Swamp, Northland, New Zealand. Journal of the Royal Society of New Zealand, 27(4), 401-418.

Elliot, M., Striewski, B., Flenley, J., \& Sutton, D. (1995). Palynological and Sedimentological Evidence for a Radiocarbon Chronology of Environmental Change and Polynesian Deforestation from Lake Taumatawhana, Northland, New Zealand 1. Radiocarbon, 37(3), 899-916.

Elliot, M. B. (1998). Late Quaternary pollen records of vegetation and climate change from Kaitaia Bog, far northern New Zealand. Review of Palaeobotany and Palynology, 99(2), 189-202.

Ellison, C. A., Skinner, Q. D., \& Hicks, L. S. (2009). Assessment of best-management practice effects on rangeland stream water quality using multivariate statistical techniques. Rangeland ecology \& management, 62(4), 371-386.

Elser, J. J., Bracken, M. E., Cleland, E. E., Gruner, D. S., Harpole, W. S., Hillebrand, H., . . Smith, J. E. (2007). Global analysis of nitrogen and phosphorus limitation of primary producers in freshwater, marine and terrestrial ecosystems. Ecol Lett, 10(12), 1135-1142. doi:10.1111/j.1461-0248.2007.01113.x

Empson, L., Flenley, J., \& Sheppard, P. (2002). A Dated Pollen Record of Vegetation Change on Mayor Island (Tuhua) throughout the Last 3000 years (Vol. 33).

Enters, D., Dörfler, W., \& Zolitschka, B. (2008). Historical soil erosion and land-use change during the last two millennia recorded in lake sediments of Frickenhauser See, northern Bavaria, central Germany. The Holocene, 18(2), 243-254.

Environment, M. f. t. (2006). Snapshot of lake water quality in New Zealand. Retrieved from http://www.mfe.govt.nz/sites/default/files/snapshot-lake-water-qualitynov06.pdf

Environment, P. C. f. t. (2004). Growing for good Intensive farming, sustainability and New Zealand's environment. Retrieved from https://www.pce.parliament.nz/media/pdfs/growing-for-good.pdf

Environment, P. C. f. t. (2012). Water quality in New Zealand: Understanding the science. Retrieved from https://www.pce.parliament.nz/media/1278/pce-waterquality-in-new-zealand.pdf

Environment, P. P. C. f. t. (2013). Water Quality in New Zealand: Land Use and Nutrient Pollution. Retrieved from https://www.pce.parliament.nz/media/1008/update-report-water-quality-in-newzealand-web.pdf 
Eppendorf. (2019). Catalog 2019. In Eppendorf (Ed.).

Evans, R. D. (1991). The impact of sediment focusing on total residual $210 \mathrm{~Pb}$ : Implications for choice of a dating model. SIL Proceedings, 1922-2010, 24(4), 2335-2339. doi:10.1080/03680770.1989.11899957

Ewers, R. M., Kliskey, A. D., Walker, S., Rutledge, D., Harding, J. S., \& Didham, R. K. (2006). Past and future trajectories of forest loss in New Zealand. Biological Conservation, 133(3), 312-325. doi:https://doi.org/10.1016/j.biocon.2006.06.018

Faegri, K., Iverson, J., \& Giovannini, L. (1989). Textbook of Pollen Analysis, John Wiley. In: Arts of Cappadocia. Nagel.

Fahey, B., \& Jackson, R. (1997). Hydrological impacts of converting native forests and grasslands to pine plantations, South Island, New Zealand. Agricultural and Forest Meteorology, 84(1-2), 69-82.

Fallon, J. (2015). The Wairarapa region. Journal of New Zealand Grasslands, 77, 1418. Retrieved from https://www.grassland.org.nz/publications/nzgrassland_publication_2709.pdf

Fay, P. (1992). Oxygen relations of nitrogen fixation in cyanobacteria. Microbiological reviews, 56(2), 340-373. Retrieved from https://www.ncbi.nlm.nih.gov/pubmed/1620069

https://www.ncbi.nlm.nih.gov/pmc/articles/PMC372871/

Fennessy, M., \& Cronk, J. (1997). The effectiveness and restoration potential of riparian ecotones for the management of nonpoint source pollution, particularly nitrate. Critical reviews in environmental science and technology, 27(4), 285-317.

Finlay, J. C., Small, G. E., \& Sterner, R. W. (2013). Human influences on nitrogen removal in lakes. Science, 342(6155), 247-250.

Fissore, D., Pisano, R., \& Barresi, A. A. (2018). Process analytical technology for monitoring pharmaceuticals freeze-drying - A comprehensive review. Drying Technology, 36(15), 1839-1865. doi:10.1080/07373937.2018.1440590

Fitzpatrick, F. A., Garrison, P. J., Fitzgerald, S. A., \& Elder, J. F. (2003). Nutrient, trace-element, and ecological history of Musky Bay, Lac Courte Oreilles, Wisconsin, as inferred from sediment cores. Water-Resources Investigations Report, 2, 4225.

Foote, K. J. (2014). The cost of milk: environmental deterioration vs. profit in the New Zealand dairy industry: a thesis submitted in partial fulfilment of the requirements for the degree of Master of Environmental Management, Institute of Agriculture and Environment, Massey University, Palmerston North, New Zealand. Massey University,

Foote, K. J., Joy, M. K., \& Death, R. G. (2015). New Zealand Dairy Farming: Milking Our Environment for All Its Worth. Environmental Management, 56(3), 709720. doi:10.1007/s00267-015-0517-x

Frank, Y. A., Kadnikov, V. V., Lukina, A. P., Banks, D., Beletsky, A. V., Mardanov, A. V., .. Ravin, N. V. (2016). Characterization and Genome Analysis of the First Facultatively Alkaliphilic Thermodesulfovibrio Isolated from the Deep Terrestrial Subsurface. Frontiers in microbiology, 7, 2000-2000. doi:10.3389/fmicb.2016.02000

Frey, D. G. (1988). Littoral and offshore communities of diatoms, cladocerans and dipterous larvae, and their interpretation in paleolimnology. Journal of Paleolimnology, 1(3), 179-191.

Gaillard, M.-J., Birks, H., Emanuelsson, U., \& Berglund, B. (1992). Modern pollen/land-use relationships as an aid in the reconstruction of past land-uses and cultural landscapes: an example from south Sweden. Vegetation history and archaeobotany, 1(1), 3-17. 
Gamrod, J. L. (2009). Paleolimnological records of environmental change preserved in Paleo-Lake Mababe, northwest Botswana. Oklahoma State University,

George, V. (2009). The Potential impact of riparian buffer zones on sediment and phosphorus loading in two Canandaigua Lake subwatersheds.

Giguet-Covex, C., Ficetola, G. F., Walsh, K., Poulenard, J., Bajard, M., Fouinat, L., . . . Arnaud, F. (2019). New insights on lake sediment DNA from the catchment: importance of taphonomic and analytical issues on the record quality. Scientific Reports, 9(1), 14676. doi:10.1038/s41598-019-50339-1

Gillon, S., Booth, E., \& Rissman, A. (2015). Shifting drivers and static baselines in environmental governance: challenges for improving and proving water quality outcomes. Regional Environmental Change, 16. doi:10.1007/s10113-015-07870

Giovannucci, D., Scherr, S. J., Nierenberg, D., Hebebrand, C., Shapiro, J., Milder, J., \& Wheeler, K. (2012). Food and Agriculture: the future of sustainability. The sustainable development in the 21st century (SD21) Report for Rio, 20.

Giresse, P., Maley, J., \& Brenac, P. (1994). Late Quaternary palaeoenvironments in the Lake Barombi Mbo (West Cameroon) deduced from pollen and carbon isotopes of organic matter. Palaeogeography, Palaeoclimatology, Palaeoecology, 107(12), 65-78.

Gold, A. J., Groffman, P. M., Addy, K., Kellogg, D., Stolt, M., \& Rosenblatt, A. E. (2001). LANDSCAPE ATTRIBUTES AS CONTROLS ON GROITHD WATER NITRATE REMOVAL CAPACITY OF RIPARIAN ZONES 1. JAWRA Journal of the American Water Resources Association, 37(6), 14571464.

Gong, D., Fan, X., Li, Y., Li, B., Zhang, N., Gromig, R., . . Talalay, P. (2019). Coring of Antarctic Subglacial Sediments. Journal of Marine Science and Engineering, 7(6), 194. Retrieved from https://www.mdpi.com/2077-1312/7/6/194

Government, N. Z. (2016). New Zealand - Economic and Financial Overview 2016. Retrieved from https://treasury.govt.nz/sites/default/files/2010-04/nzefo-16.pdf

Grant, R., Laubel, A., Kronvang, B., Andersen, H. E., Svendsen, L. M., \& Fuglsang, A. (1996). Loss of dissolved and particulate phosphorus from arable catchments by subsurface drainage. Water Research, 30(11), 2633-2642. doi:https://doi.org/10.1016/S0043-1354(96)00164-9

Gray, C., McLaren, R., Roberts, A., \& Condron, L. (1998). Sorption and desorption of cadmium from some New Zealand soils: effect of $\mathrm{pH}$ and contact time. Soil Research, 36(2), 199-216.

Greenfield, S., Milne, J., Perrie, A., Oliver, M., Tidswell, S., \& Crisp, P. (2014). Aquatic ecosystem health and contact recreation outcomes in the draft Natural Resources Plan.

Greenwood, M. J., Harding, J. S., Niyogi, D. K., \& McIntosh, A. R. (2012). Improving the effectiveness of riparian management for aquatic invertebrates in a degraded agricultural landscape: stream size and land-use legacies. Journal of Applied Ecology, 49(1), 213-222.

Gregory, S., Swanson, F., Arthur McKee, W., \& Cummins, K. (1991). An Ecosystem Perspective of Riparian Zones (Vol. 41).

Groffman, P. M., Baron, J. S., Blett, T., Gold, A. J., Goodman, I., Gunderson, L. H., . . Wiens, J. (2006). Ecological Thresholds: The Key to Successful Environmental Management or an Important Concept with No Practical Application? Ecosystems, 9(1), 1-13. doi:10.1007/s10021-003-0142-z

Grosjean, M., Amann, B. J.-F., Butz, C. F., Rein, B., \& Tylmann, W. (2014). Hyperspectral imaging: a novel, non-destructive method for investigating subannual sediment structures and composition. PAGES news, 22(1), 10-11. 
Guggenmos, M., Daughney, C., Jackson, B., \& Morgenstern, U. (2011). Regional-scale identification of groundwater-surface water interaction using hydrochemistry and multivariate statistical methods, Wairarapa Valley, New Zealand. Hydrology and Earth System Sciences, 15(11), 3383-3398.

Haggerty, J., Campbell, H., \& Morris, C. (2009). Keeping the stress off the sheep? Agricultural intensification, neoliberalism, and 'good' farming in New Zealand. Geoforum, 40(5), 767-777. doi:https://doi.org/10.1016/j.geoforum.2008.12.003

Hajdas, I., Ivy-Ochs, S. D., \& Bonani, G. (1995). Problems in the extension of the radiocarbon calibration curve (10-13 kyr BP). Radiocarbon, 37(1), 75-79.

Håkanson, L., \& Jansson, M. (1983). Principles of lake sedimentology (Vol. 316): Springer-verlag Berlin.

Hall, \& Smol. (2010). Diatomsasindicatorsof lakeeutrophication. The diatoms: applications for the environmental and earth sciences, 122.

Hall, K. J., \& Schreier, H. (1996). Urbanization and agricultural intensification in the Lower Fraser River valley,: Impacts on water use and quality. GeoJournal, 40(1), 135-146. doi:10.1007/BF00222539

Hall, R. I., Smol, J. P., \& Smol, J. (1999). Diatoms as indicators of lake eutrophication. The diatoms: applications for the environmental and earth sciences, 128-168.

Hamilton, D. P., \& Schladow, S. G. (1997). Prediction of water quality in lakes and reservoirs. Part I - Model description. Ecological Modelling, 96(1), 91-110. doi:https://doi.org/10.1016/S0304-3800(96)00062-2

Hamza, I. A., Jurzik, L., Überla, K., \& Wilhelm, M. (2011). Evaluation of pepper mild mottle virus, human picobirnavirus and Torque teno virus as indicators of fecal contamination in river water. Water Research, 45(3), 1358-1368.

Hansen, B., Reich, P., Lake, P. S., \& Cavagnaro, T. (2010). Minimum width requirements for riparian zones to protect flowing waters and to conserve biodiversity: a review and recommendations with application to the State of Victoria. Monash University, Melbourne.

Harding, J. S. (2009). Stream Habitat Assessment Protocols for wadeable rivers and streams in New Zealand: University of Canterbury, School of Biological Sciences.

Harper, D. M., Phillips, G., Chilvers, A., Kitaka, N., \& Mavuti, K. (1993). Eutrophication prognosis for Lake Naivasha, Kenya. Internationale Vereinigung für theoretische und angewandte Limnologie: Verhandlungen, 25(2), 861-865.

Harris, J. K., Sahl, J. W., Castoe, T. A., Wagner, B. D., Pollock, D. D., \& Spear, J. R. (2010). Comparison of normalization methods for construction of large, multiplex amplicon pools for next-generation sequencing. Applied and environmental microbiology, 76(12), 3863-3868. doi:10.1128/AEM.02585-09

Hawes, E., \& Smith, M. (2005). Riparian buffer zones: functions and recommended widths. Eightmile River Wild and Scenic Study Committee, 15, 2005.

Hawke, R., \& Summers, S. (2003). Land application of farm dairy effluent: results from a case study, Wairarapa, New Zealand.

Heath, D. (1979). Holocene Marine Shorelines of the Wairarapa. Unpub. BSc (Hons) thesis in Geology, Department of Geology, Victoria University of Wellington, Wellington, New Zealand.

Heathwaite, A. L. (1994). Chemical fractionation of lake sediments to determine the effects of land-use change on nutrient loading. Journal of Hydrology, 159(1-4), 395-421.

Heathwaite, A. L., Quinn, P. F., \& Hewett, C. J. M. (2005). Modelling and managing critical source areas of diffuse pollution from agricultural land using flow connectivity simulation. Journal of Hydrology, 304(1), 446-461. doi:https://doi.org/10.1016/j.jhydrol.2004.07.043 
Heiri, O., Lotter, A. F., \& Lemcke, G. (2001). Loss on ignition as a method for estimating organic and carbonate content in sediments: reproducibility and comparability of results. Journal of Paleolimnology, 25(1), 101-110. doi:10.1023/a:1008119611481

Hénault-Ethier, L., Lucotte, M., Smedbol, É., Gomes, M. P., Maccario, S., Laprise, M. E. L., . . Labrecque, M. (2019). Potential Efficiency of Grassy or Shrub Willow Buffer Strips against Nutrient Runoff from Soybean and Corn Fields in Southern Quebec, Canada. Journal of Environmental Quality, 48, 352-361. doi:10.2134/jeq2016.10.0391

Herczeg, A. L., Smith, A. K., \& Dighton, J. C. (2001). A 120 year record of changes in nitrogen and carbon cycling in Lake Alexandrina, South Australia: C:N, ??15N and ??13C in sediments. Applied Geochemistry, 16, 73-84. doi:10.1016/S08832927(00)00016-0

Herlemann, D. P., Labrenz, M., Jurgens, K., Bertilsson, S., Waniek, J. J., \& Andersson, A. F. (2011). Transitions in bacterial communities along the $2000 \mathrm{~km}$ salinity gradient of the Baltic Sea. Isme j, 5(10), 1571-1579. doi:10.1038/ismej.2011.41

Higham, T., Anderson, A., \& Jacomb, C. (1999). Dating the first New Zealanders: the chronology of Wairau Bar. Antiquity, 73(280), 420-427.

Higuera, P. E., Peters, M. E., Brubaker, L. B., \& Gavin, D. G. (2007). Understanding the origin and analysis of sediment-charcoal records with a simulation model. Quaternary Science Reviews, 26(13-14), 1790-1809.

Hill, R. (1963a). Elastic properties of reinforced solids: some theoretical principles. Journal of the Mechanics and Physics of Solids, 11(5), 357-372.

Hill, R. D. (1963b). THE VEGETATION OF THE WAIRARAPA IN MIDNINETEENTH CENTURY. TUATARA, 11(2).

Hilt, S., Brothers, S., Jeppesen, E., Veraart, A. J., \& Kosten, S. (2017). Translating regime shifts in shallow lakes into changes in ecosystem functions and services. BioScience, 67(10), 928-936.

Hindson, B. J., Ness, K. D., Masquelier, D. A., Belgrader, P., Heredia, N. J., Makarewicz, A. J., . . . Legler, T. C. (2011). High-throughput droplet digital PCR system for absolute quantitation of DNA copy number. Analytical chemistry, 83(22), 8604-8610.

Hines, B., Kulhanek, D., Hollis, C., Atkins, C., \& Morgans, H. (2013). PaleoceneEocene stratigraphy and paleoenvironment at Tora, Southeast Wairarapa, New Zealand. New Zealand Journal of Geology and Geophysics, 56(4), 243-262.

Hoffman, C., Kjaergaard, C., Uusi-Kamppa, J., \& Hansen, H. (2009). B., \& Kronvang, B.(2009). Phosphorus retention in riparian buffers: review of their efficiency. Journal of Environmental Quality, 38(5), 142-1955.

Hogg, A. G., Hua, Q., Blackwell, P. G., Niu, M., Buck, C. E., Guilderson, T. P., . . Reimer, R. W. (2013). SHCal13 Southern Hemisphere calibration, 0-50,000 years cal BP. Radiocarbon, 55(4), 1889-1903.

Hooda, P., Edwards, A., Anderson, H., \& Miller, A. (2000). A review of water quality concerns in livestock farming areas. Science of The Total Environment, 250(13), 143-167.

Horrocks, M., Nichol, S., Augustinus, P., \& Barber, I. (2007). Late Quaternary environments, vegetation and agriculture in northern New Zealand. Journal of Quaternary Science, 22(3), 267-279.

House, W., \& Denison, F. (2000). Factors influencing the measurement of equilibrium phosphate concentrations in river sediments. Water Research, 34(4), 1187-1200.

Howard-Williams, C., \& Kelly, D. (2003). 5-2. Local Perspectives in Lake Restoration and Rehabilitation. Freshwater Management: Global Versus Local Perspectives, 153. 
Howarth, J. D., Fitzsimons, S. J., Jacobsen, G. E., Vandergoes, M. J., \& Norris, R. J. (2013). Identifying a reliable target fraction for radiocarbon dating sedimentary records from lakes. Quaternary Geochronology, 17, 68-80.

Hua, Q., Barbetti, M., \& Rakowski, A. Z. (2013). Atmospheric radiocarbon for the period 1950-2010. Radiocarbon, 55(4), 2059-2072.

Ilhardt, B. L., Verry, E. S., \& Palik, B. J. (2000). Defining riparian areas. Forestry and the riparian zone, Orono, Maine, 7-14.

Illumina. (2019). TruSeq SBS Kit v3-HS. Retrieved from https://www.illumina.com/products/by-type/sequencing-kits/cluster-gensequencing-reagents/truseq-sbs-kit-v3-hs.html

Jensen, H. S., Kristensen, P., Jeppesen, E., \& Skytthe, A. (1992). Iron: phosphorus ratio in surface sediment as an indicator of phosphate release from aerobic sediments in shallow lakes. In Sediment/Water Interactions (pp. 731-743): Springer.

Johansen, K., \& Phinn, S. (2006). Mapping structural parameters and species composition of riparian vegetation using IKONOS and Landsat ETM+ data in Australian tropical savannahs. Photogrammetric Engineering \& Remote Sensing, 72(1), 71-80.

Johansen, K., Phinn, S., \& Witte, C. (2010). Mapping of riparian zone attributes using discrete return LiDAR, QuickBird and SPOT-5 imagery: Assessing accuracy and costs. Remote Sensing of Environment, 114(11), 2679-2691.

Jorgensen, E. E., Canfield, T. J., \& Kutz, F. W. (2000). Restored riparian buffers as tools for ecosystem restoration in the MAIA; processes, endpoints, and measures of success for water, soil, flora, and fauna. Environmental Monitoring and Assessment, 63(1), 199-210.

Kachiuru, M. (2013). 4 Prokaryotic community composition of four Kenyan soda lakes as revealed by amplicon sequencing. METAGENOMIC AND METATRANSCRIPTOMIC ANALYSES OF CALCIFYING BIOFILMS, 99.

Kamp, P. (1992). Landforms of Wairarapa: a geological perspective. Landforms of New Zealand, 2.

Kane, D. D., Conroy, J. D., Richards, R. P., Baker, D. B., \& Culver, D. A. (2014). Reeutrophication of Lake Erie: Correlations between tributary nutrient loads and phytoplankton biomass. Journal of Great Lakes Research, 40(3), 496-501.

Kashiwaya, K., Yamamoto, A., \& Fukuyama, K. (1987). Time variations of erosional force and grain size in Pleistocene lake sediments. Quaternary Research, 28(1), 61-68.

Kauffman, J. B., \& Krueger, W. C. (1984). Livestock impacts on riparian ecosystems and streamside management implications... a review. Journal of range management, 37(5), 430-438.

Kaushal, S., \& Binford, M. W. (1999). Relationship between C: N ratios of lake sediments, organic matter sources, and historical deforestation in Lake Pleasant, Massachusetts, USA. Journal of Paleolimnology, 22(4), 439-442.

Khan, F. A., \& Ansari, A. A. (2005). Eutrophication: an ecological vision. The botanical review, 71(4), 449-482.

King, J., Banerjee, S. K., Marvin, J., \& Özdemir, Ö. (1982). A comparison of different magnetic methods for determining the relative grain size of magnetite in natural materials: some results from lake sediments. Earth and Planetary Science Letters, 59(2), 404-419.

King, N. A. H. A. B. (2015). What Drives Seismic Risk in New Zealand? Insights from a nextgeneration loss model. Retrieved from PO Box 30 368, Lower Hutt 5040, New Zealand:

Kissling, W. D., Schnittler, M., Seddon, P. J., Dickinson, K. J. M., \& Lord, J. M. (2005). Invasion ecology of the alien tussock grass Nardus stricta (Poaceae) at 
Lake Pukaki, Canterbury, New Zealand. New Zealand journal of botany, 43(3), 601-612. doi:10.1080/0028825X.2005.9512977

Kleeberg, A., \& Dudel, G. (1997). Changes in extent of phosphorus release in a shallow lake (Lake Großer Müggelsee; Germany, Berlin) due to climatic factors and load. Marine Geology, 139(1-4), 61-75.

Klindworth, A., Pruesse, E., Schweer, T., Peplies, J., Quast, C., Horn, M., \& Glockner, F. O. (2013). Evaluation of general 16S ribosomal RNA gene PCR primers for classical and next-generation sequencing-based diversity studies. Nucleic Acids Res, 41(1), e1. doi:10.1093/nar/gks808

Korsman, T., \& Birks, H. (1996). Diatom-based water chemistry reconstructions from northern Sweden: a comparison of reconstruction techniques. Journal of Paleolimnology, 15(1), 65-77.

Kronvang, B., Laubel, A., \& Grant, R. (1997). SUSPENDED SEDIMENT AND PARTICULATE PHOSPHORUS TRANSPORT AND DELIVERY PATHWAYS IN AN ARABLE CATCHMENT, GELBÆK STREAM, DENMARK. Hydrological Processes, 11(6), 627-642. doi:10.1002/(sici)10991085(199705)11:6<627::Aid-hyp481>3.0.Co;2-e

Langdon, P. G., Ruiz, Z., Brodersen, K. P., \& Foster, I. D. (2006). Assessing lake eutrophication using chironomids: understanding the nature of community response in different lake types. Freshwater biology, 51(3), 562-577.

Larned, S. S., T; Unwin, M; McBride, G; Verbug, P; McMillian, H. (2015). Analysis of water quality in New Zealand lakes and rivers: Data sources, data sets, assumptions, limitations, methods and results. Retrieved from Ministry for the Environment:

Leach, B. (1984). The terminal age for the Lower Wairarapa estuarine environment. $J R$ Soc. New Zeal, 14, 207-298.

Leach, B., \& Anderson, A. (1974). The transformation from an estuarine to lacustrine environment in the lower Wairarapa. Journal of the Royal Society of New Zealand, 4(3), 267-275.

Leach, B. F. (1981). The prehistory of the southern Wairarapa. Journal of the Royal Society of New Zealand, 11(1), 11-33.

Leavitt, P. R., Fritz, S. C., Anderson, N., Baker, P., Blenckner, T., Bunting, L., . . . Jeppesen, E. (2009). Paleolimnological evidence of the effects on lakes of energy and mass transfer from climate and humans. Limnology and oceanography, 54(6part2), 2330-2348.

Lee, J., \& Begg, J. (2002). Geology of the Wairarapa area (Vol. 11).

Lee, J. M., Begg, J., \& Forsyth, P. (2002). Geology of the Wairarapa area: Institute of Geological \& Nuclear Sciences.

Legendre, P., \& Legendre, L. F. (2012). Numerical ecology: Elsevier.

LGGA, L. G. G. A. (2019). Retrolens. Retrieved from http://retrolens.nz/

Lim, N. K., Tay, Y. C., Srivathsan, A., Tan, J. W., Kwik, J. T., Baloglu, B., . . Yeo, D. C. (2016). Next-generation freshwater bioassessment: eDNA metabarcoding with a conserved metazoan primer reveals species-rich and reservoir-specific communities. $R$ Soc Open Sci, 3(11), 160635. doi:10.1098/rsos.160635

Liu, J., Lauterbach, R., Paulsen, H., \& Knoll, W. (2008). Immobilization of lightharvesting chlorophyll $\mathrm{a} / \mathrm{b}$ complex (LHCIIb) studied by surface plasmon fieldenhanced fluorescence spectroscopy. Langmuir, 24(17), 9661-9667.

Liu, W., \& Qiu, R. (2007). Water eutrophication in China and the combating strategies. Journal of Chemical Technology \& Biotechnology: International Research in Process, Environmental \& Clean Technology, 82(9), 781-786. 
Liu, X., Zhang, X., \& Zhang, M. (2008). Major factors influencing the efficacy of vegetated buffers on sediment trapping: A review and analysis. Journal of Environmental Quality, 37(5), 1667-1674.

Liu, Y.-F., Qi, Z.-Z., Shou, L.-B., Liu, J.-F., Yang, S.-Z., Gu, J.-D., \& Mu, B.-Z. (2019). Anaerobic hydrocarbon degradation in candidate phylum 'Atribacteria'(JS1) inferred from genomics. The ISME journal, 13(9), 23772390.

Lotter, A. F., Birks, H. J. B., Hofmann, W., \& Marchetto, A. (1998). Modern diatom, cladocera, chironomid, and chrysophyte cyst assemblages as quantitative indicators for the reconstruction of past environmental conditions in the Alps. II. Nutrients. Journal of Paleolimnology, 19(4), 443-463.

Lowe, J. J., \& Walker, M. J. (2014). Reconstructing quaternary environments: Routledge.

Lowrance, R., Todd, R., Fail Jr, J., Hendrickson Jr, O., Leonard, R., \& Asmussen, L. (1984). Riparian forests as nutrient filters in agricultural watersheds. BioScience, 34(6), 374-377.

Lü, C., Wang, B., He, J., Vogt, R. D., Zhou, B., Guan, R., . . Wang, J. (2016). Responses of organic phosphorus fractionation to environmental conditions and lake evolution. Environmental science \& technology, 50(10), 5007-5016.

Lyver, P. O. B., Wilmshurst, J. M., Wood, J. R., Jones, C. J., Fromont, M., Bellingham, P. J., . . . Moller, H. (2015). Looking back for the future: local knowledge and palaeoecology inform biocultural restoration of coastal ecosystems in New Zealand. Human ecology, 43(5), 681-695.

Ma, L. Q., \& Rao, G. N. (1997). Chemical fractionation of cadmium, copper, nickel, and zinc in contaminated soils. Journal of Environmental Quality, 26(1), 259264.

MacLeod, C. J., \& Moller, H. (2006a). Intensification and diversification of New Zealand agriculture since 1960: An evaluation of current indicators of land use change. Agriculture, ecosystems \& environment, 115(1-4), 201-218.

MacLeod, C. J., \& Moller, H. (2006b). Intensification and diversification of New Zealand agriculture since 1960: An evaluation of current indicators of land use change. Agriculture, ecosystems \& environment, 115(1), 201-218. doi:https://doi.org/10.1016/j.agee.2006.01.003

Mair, G. M. (1972). The protohistoric period of Wairarapa culture history. University of Otago,

Mankin, K. R., Ngandu, D. M., Barden, C. J., Hutchinson, S. L., \& Geyer, W. A. (2007). Grass-Shrub Riparian Buffer Removal of Sediment, Phosphorus, and Nitrogen From Simulated Runoff1. JAWRA Journal of the American Water Resources Association, 43(5), 1108-1116. doi:10.1111/j.17521688.2007.00090.x

Manny, B. A., Wetzel, R. G., \& Bailey, R. E. (1977). Paleolimnological sedimentation of organic carbon, nitrogen, phosphorus, fossil pigments, pollen, and diatoms in a hypereutrophic, hardwater lake: A case history of eutrophication. Retrieved from

Martin, T. L., Kaushik, N., Trevors, J., \& Whiteley, H. (1999). Denitrification in temperate climate riparian zones. Water, Air, and Soil Pollution, 111(1-4), 171186.

McDowell, R., Taylor, M., \& Stevenson, B. (2013). Natural background and anthropogenic contributions of cadmium to New Zealand soils. Agriculture, ecosystems \& environment, 165, 80-87. 
McFadgen, Knox, F., \& Cole, T. (1994). Radiocarbon calibration curve variations and their implications for the interpretation of New Zealand prehistory.

Radiocarbon, 36(2), 221-236.

McFadgen, B. (2003a). Archaeology of the Wellington Conservancy: Wairarapa. A study in tectonic archaeology. Department of Conservation, Wellington.

McFadgen, B. (2003b). McFadgen, B.G. 2003. Archaeology of the Wellington Conservancy: Wairarapa: a study in tectonic archaeology. Department of Conservation. 94pp.

McGeehin, J., Burr, G. S., Jull, A. T., Reines, D., Gosse, J., Davis, P., . . Southon, J. R. (2001). Stepped-combustion $14 \mathrm{C}$ dating of sediment: a comparison with established techniques. Radiocarbon, 43(2A), 255-261.

McGlone, \& Wilmshurst, J. M. (1999a). Dating initial Maori environmental impact in New Zealand. Quaternary International, 59(1), 5-16.

McGlone, M. (1983a). Holocene pollen diagrams, Lake Rotorua, North Island, New Zealand. Journal of the Royal Society of New Zealand, 13(1-2), 53-65.

McGlone, M. (1983b). Polynesian deforestation of New Zealand: a preliminary synthesis. Archaeology in oceania, 18(1), 11-25.

McGlone, M. (1989a). The Polynesian settlement of New Zealand in relation to environmental and biotic changes. New Zealand journal of ecology, 115-129.

McGlone, M. (1989b). The Polynesian settlement of New Zealand in relation to environmental and biotic changes. New Zealand journal of ecology, 12(Supplement), 115-129.

McGlone, M., \& Wilmshurst, J. (1999b). A Holocene record of climate, vegetation change and peat bog development, east Otago, South Island, New Zealand. Journal of Quaternary Science: Published for the Quaternary Research Association, 14(3), 239-254.

McGlone, M. S., \& Wilmshurst, J. M. (1999c). doi:- 10.1016/s1040-6182(98)00067-6

McGlone, M. S., \& Wilmshurst, J. M. (1999d). Dating initial Maori environmental impact in New Zealand. Quaternary International, 59(1), 5-16.

McIntrye, R. (2002). The Canoes of Kupe A history of the Martinborough District. Victoria University, Wellington. Retrieved from http://researcharchive.vuw.ac.nz/bitstream/handle/10063/1677/thesis.pdf?sequen ce $=1$

McIntyre, R. (2012). The Canoes of Kupe: A History of Martinborough District: Wairarapa Archive.

McLintock, A. H. (1966a). Encyclopaedia of New Zealand.

McLintock, A. H. (1966b). History of Aerial Topdressing

McMurdie, P. J., \& Holmes, S. (2013). phyloseq: an R package for reproducible interactive analysis and graphics of microbiome census data. PLoS One, 8(4), e61217. doi:10.1371/journal.pone.0061217

McWethy, D., Higuera, P., Whitlock, C., Veblen, T., Bowman, D., Cary, G., . . . McGlone, M. (2013). A conceptual framework for predicting temperate ecosystem sensitivity to human impacts on fire regimes. Global Ecology and Biogeography, 22(8), 900-912.

McWethy, D. B., Whitlock, C., Wilmshurst, J. M., McGlone, M. S., Fromont, M., Li, X., . . Cook, E. R. (2010). Rapid landscape transformation in South Island, New Zealand, following initial Polynesian settlement. Proceedings of the National Academy of Sciences, 107(50), 21343-21348. doi:10.1073/pnas.1011801107

McWethy, D. B., Whitlock, C., Wilmshurst, J. M., McGlone, M. S., \& Li, X. (2009). Rapid deforestation of south island, New Zealand, by early Polynesian fires. The Holocene, 19(6), 883-897. 
McWethy, D. B., Wilmshurst, J. M., Whitlock, C., Wood, J. R., \& McGlone, M. S. (2014). A high-resolution chronology of rapid forest transitions following Polynesian arrival in New Zealand. PLoS One, 9(11).

Medema, G., Shaw, S., Waite, M., Snozzi, M., Morreau, A., \& Grabow, W. (2003). Catchment characterisation and source water quality. Assessing Microbial Safety of Drinking Water, 111.

Miller, J. J., Curtis, T., Chanasyk, D. S., Reedyk, S., \& Willms, W. D. (2016). Effectiveness of soil in vegetated buffers to retain nutrients and sediment transported by concentrated runoff through deep gullies. Canadian Journal of Soil Science, 96(2), 154-168. doi:10.1139/cjss-2015-0038

Mills, K., Schillereff, D., Saulnier-Talbot, É., Gell, P., Anderson, N. J., Arnaud, F., . . . Massaferro, J. (2017). Deciphering long-term records of natural variability and human impact as recorded in lake sediments: A palaeolimnological puzzle. Wiley Interdisciplinary Reviews: Water, 4(2), e1195.

Ministry for the Environment. (2014). National Policy Statement for Freshwater Management 2014 (amended 2017).

Miskell, B. (2010). WAIRARAPA - LANDSCAPE STUDY 2010 - Landscape Character Description. Retrieved from http://www.gw.govt.nz/assets/councilpublications/Wairarapa\%20Character\%20Study\%20August\%202010.pdf

Moller, H., MacLeod, C. J., Haggerty, J., Rosin, C., Blackwell, G., Perley, C., . . . Gradwohl, M. (2008). Intensification of New Zealand agriculture: implications for biodiversity. New Zealand Journal of Agricultural Research, 51(3), 253-263.

Moore, S. K., Trainer, V. L., Mantua, N. J., Parker, M. S., Laws, E. A., Backer, L. C., \& Fleming, L. E. (2008). Impacts of climate variability and future climate change on harmful algal blooms and human health. Environmental Health, 7(2), S4. doi:10.1186/1476-069X-7-S2-S4

Morgenstern, U., \& Daughney, C. J. (2012). Groundwater age for identification of baseline groundwater quality and impacts of land-use intensification - The National Groundwater Monitoring Programme of New Zealand. Journal of Hydrology, 456-457, 79-93. doi:https://doi.org/10.1016/j.jhydrol.2012.06.010

Myers, S. C., Clarkson, B. R., Reeves, P. N., \& Clarkson, B. D. (2013). Wetland management in New Zealand: Are current approaches and policies sustaining wetland ecosystems in agricultural landscapes? Ecological Engineering, 56, 107-120. doi:https://doi.org/10.1016/j.ecoleng.2012.12.097

Nelson, N. O., Parsons, J. E., \& Mikkelsen, R. L. (2005). Field-Scale Evaluation of Phosphorus Leaching in Acid Sandy Soils Receiving Swine Waste Mention of trademarks, proprietary products, or vendors does not constitute a guarantee or warranty of the product by the USDA-ARS and does not imply its approval to the exclusion of other products or vendors that may also be suitable. Journal of Environmental Quality, 34(6), 2024-2035. doi:10.2134/jeq2004.0445

Newnham, R., Lowe, D., McGlone, M., Wilmshurst, J., \& Higham, T. (1998). The Kaharoa Tephra as a critical datum for earliest human impact in northern New Zealand. Journal of archaeological science, 25(6), 533-544.

Newnham, R. M., Lowe, D. J., \& Matthews, B. W. (1998). A late-Holocene and prehistoric record of environmental change from Lake Waikaremoana, New Zealand. The Holocene, 8(4), 443-454.

Newsome, P. (1987), vegetative cover of New Zealand.

Nielsen, A., Trolle, D., Bjerring, R., Søndergaard, M., Olesen, J. E., Janse, J. H., . . . Jeppesen, E. (2014). Effects of climate and nutrient load on the water quality of shallow lakes assessed through ensemble runs by PCLake. Ecological Applications, 24(8), 1926-1944. 
Nobu, M. K., Dodsworth, J. A., Murugapiran, S. K., Rinke, C., Gies, E. A., Webster, G., ... Sass, H. (2016). Phylogeny and physiology of candidate phylum 'Atribacteria'(OP9/JS1) inferred from cultivation-independent genomics. The ISME journal, 10(2), 273-286.

Norton, L., Elliott, J. A., Maberly, S. C., \& May, L. (2012). Using models to bridge the gap between land use and algal blooms: An example from the Loweswater catchment, UK. Environmental Modelling \& Software, 36, 64-75.

NZ, S. (2019). Agricultural and horticultural land use. Retrieved from http://archive.stats.govt.nz/browse_for_stats/environment/environmentalreporting-series/environmental-indicators/Home/Land/land-use.aspx

Ogden, J., Deng, Y., Boswijk, G., \& Sandiford, A. (2003). Vegetation changes since early Maori fires in Waipoua Forest, northern New Zealand. Journal of archaeological science, 30(6), 753-767.

Ogden, J., Deng, Y., Horrocks, M., Nichol, S., \& Anderson, S. (2006). Sequential impacts of Polynesian and European settlement on vegetation and environmental processes recorded in sediments at Whangapoua Estuary, Great Barrier Island, New Zealand. Regional Environmental Change, 6(1-2), 25-40.

Oksanen, J., Blanchet, F. G., Kindt, R., Legendre, P., Minchin, P. R., O’hara, R., . . . Wagner, H. (2013). Package 'vegan'. Community ecology package, version, 2(9), 1-295.

Okuda, M., Shulmeister, J., \& Flenley, J. (2002). Vegetation changes and their climatic implication for the late Pleistocene at Lake Poukawa, Hawkes Bay, New Zealand. Global and Planetary Change, 33(3-4), 269-282.

Oldfield, F., \& Appleby, P. (1984). Empirical testing of $210 \mathrm{~Pb}$-dating models for lake sediments. In Lake sediments and environmental history.

Oliver, D. M., Clegg, C. D., Haygarth, P. M., \& Heathwaite, A. L. (2005). Assessing the potential for pathogen transfer from grassland soils to surface waters. Advances in agronomy, 85(85), 125-180.

Oris, F., Ali, A. A., Asselin, H., Paradis, L., Bergeron, Y., \& Finsinger, W. (2014). Charcoal dispersion and deposition in boreal lakes from 3 years of monitoring: Differences between local and regional fires. Geophysical research letters, 41(19), 6743-6752.

Osborne, L. L., \& Kovacic, D. A. (1993). Riparian vegetated buffer strips in waterquality restoration and stream management. Freshwater biology, 29(2), 243-258.

Paerl, H. W., Fulton, R. S., Moisander, P. H., \& Dyble, J. (2001). Harmful freshwater algal blooms, with an emphasis on cyanobacteria. The Scientific World Journal, 1,76-113.

Page, M., Trustrum, N., \& DeRose, R. (1994). A high resolution record of storminduced erosion from lake sediments, New Zealand. Journal of Paleolimnology, 11(3), 333-348.

Parducci, L., Bennett, K. D., Ficetola, G. F., Alsos, I. G., Suyama, Y., Wood, J. R., \& Pedersen, M. W. (2017). Ancient plant DNA in lake sediments. New Phytologist, 214(3), 924-942. doi:10.1111/nph.14470

Parkyn, S. (2000). Review of information on riparian buffer widths necessary to support sustainable vegetation and meet aquatic functions. In W. B. Shaw, P. A. Eades, C. Auckland . Regional, W. National Institute of, \& R. Atmospheric (Eds.). Auckland, N.Z.]: Auckland, N.Z. : Auckland Regional Council.

Parkyn, S. (2004). Review of riparian buffer zone effectiveness (Vol. 2005): Citeseer.

Parkyn, S., Shaw, W., \& Eades, P. (2000). Review of information on riparian buffer widths necessary to support sustainable vegetation and meet aquatic functions.

Parkyn, S. M., Davies-Colley, R. J., Halliday, N. J., Costley, K. J., \& Croker, G. F. (2003). Planted Riparian Buffer Zones in New Zealand: Do They Live Up to 
Expectations? Restoration Ecology, 11(4), 436-447. doi:10.1046/j.1526100X.2003.rec0260.x

Patterson III, W. A., Edwards, K. J., \& Maguire, D. J. (1987). Microscopic charcoal as a fossil indicator of fire. Quaternary Science Reviews, 6(1), 3-23.

Peden, R. (2008). Farming in the economy - The golden years, 1950s to 1980s. Retrieved from https://teara.govt.nz/en/farming-in-the-economy/page-7

Pedersen, M. W., Ginolhac, A., Orlando, L., Olsen, J., Andersen, K., Holm, J., . . . Kjær, K. H. (2013). A comparative study of ancient environmental DNA to pollen and macrofossils from lake sediments reveals taxonomic overlap and additional plant taxa. Quaternary Science Reviews, 75, 161-168.

Peirce, J. J. (1998). Environmental pollution and control. In P. A. Vesilind, R. F. Weiner, \& I. ebrary (Eds.), (4th ed. / J. Jeffrey Peirce, Ruth F. Weiner, P. Aarne Vesilind.. ed.). Boston: Boston : Butterworth-Heinemann.

Penn, M. R., Auer, T., Van Orman, E. L., \& Korienek, J. J. (1995). Phosphorus diagenesis in lake sediments: investigations using fractionation techniques. Marine and Freshwater Research, 46(1), 89-99.

Perry, G. L., Wilmshurst, J. M., McGlone, M. S., McWethy, D. B., \& Whitlock, C. (2012). Explaining fire-driven landscape transformation during the Initial Burning Period of N ew Z ealand's prehistory. Global Change Biology, 18(5), 1609-1621.

Pike;, P. J. E. V. R. T. M. S., \& Hanmore, I. (2017). Analysis of drivers and barriers to land use change. Retrieved from

Qiagen. (2019). QIAcube Connect. Retrieved from https://www.qiagen.com/us/products/instruments-and-automation/nucleic-acidpurification/qiacube-connect/\#orderinginformation

Quinn, J., Cooper, A., \& Williamson, R. (1993). Riparian zones as buffer strips: a New Zealand perspective. Paper presented at the Ecology and management of riparian zones in Australia. Proceedings of a National Workshop on research and management needs for riparian zones in Australia, held in association with the 32nd annual congress of the Australian Society for Limnology, Marcoola.

Quinn, J. M., Brown, P. M., Boyce, W., Mackay, S., Taylor, A., \& Fenton, T. (2001). RIPARIAN ZONE CLASSIFICATION FOR MANAGEMENT OF STREAM WATER QUALITY AND ECOSYSTEM HEALTH 1. JAWRA Journal of the American Water Resources Association, 37(6), 1509-1515.

Rabeni, C. F., \& Smale, M. A. (1995). Effects of siltation on stream fishes and the potential mitigating role of the buffering riparian zone. Hydrobiologia, 303(1-3), 211-219.

Rafferty, M. L. (2009). The Initial Assessment of Earthquake Prone Buildings:

A Wairarapa Experience. Retrieved from

Ramsey, C. B. (2000). OxCal Program v. 3.5. University of Oxford, Radiocarbon Accelerator Unit. url: http://www. rlaha. ox. ac. uk/oxcal/oxcal. htm.

Ramsey, C. B. (2008). Deposition models for chronological records. Quaternary Science Reviews, 27(1), 42-60. doi:https://doi.org/10.1016/j.quascirev.2007.01.019

Rawlence, N. J., Lowe, D. J., Wood, J. R., Young, J. M., Churchman, G. J., HUANG, Y. T., \& Cooper, A. (2014). Using palaeoenvironmental DNA to reconstruct past environments: progress and prospects. Journal of Quaternary Science, 29(7), 610-626.

Reeves, P., Collier, K., \& Suren, A. (2004). Aquatic and riparian vegetation of rivers and streams. Freshwaters of New Zealand. Christchurch: New Zealand Hydrological Society and New Zealand Limnological Society. 
Reilly, B., Stoner, J., \& Wiest, J. (2017). Sed CT: MATLAB ${ }^{\mathrm{TM}}$ tools for standardized and quantitative processing of sediment core computed tomography (CT) data collected using a medical CT scanner. Geochemistry, Geophysics, Geosystems, 18(8), 3231-3240.

Reimer, P. J., Bard, E., Bayliss, A., Beck, J. W., Blackwell, P. G., Ramsey, C. B., . . Friedrich, M. (2013). IntCal13 and Marine13 radiocarbon age calibration curves 0-50,000 years cal BP. Radiocarbon, 55(4), 1869-1887.

Rein, B., \& Sirocko, F. (2002). In-situ reflectance spectroscopy-analysing techniques for high-resolution pigment logging in sediment cores. International Journal of Earth Sciences, 91(5), 950-954.

Reischer, G. H., Kasper, D. C., Steinborn, R., Mach, R. L., \& Farnleitner, A. H. (2006). Quantitative PCR method for sensitive detection of ruminant fecal pollution in freshwater and evaluation of this method in alpine karstic regions. Applied and environmental microbiology, 72(8), 5610-5614. doi:10.1128/AEM.00364-06

Roberts, A. H. C. (1981). Adsorption of zinc and cadmium by soils and synthetic hydrous metal oxides: a thesis presented in partial fulfilment of the requirements for the degree of Doctor of Philosophy in Soil Science at Massey University. Massey University,

Rosén, P., Segerström, U., Eriksson, L., Renberg, I., \& Birks, H. J. B. (2001). Holocene climatic change reconstructed from diatoms, chironomids, pollen and nearinfrared spectroscopy at an alpine lake (Sjuodjijaure) in northern Sweden. The Holocene, 11(5), 551-562.

Rowlinson, L. C., Summerton, M., \& Ahmed, F. (1999). Comparison of remote sensing data sources and techniques for identifying and classifying alien invasive vegetation in riparian zones.

Ruhland, K., Paterson, A. M., \& Smol, J. P. (2008). Hemispheric-scale patterns of climate-related shifts in planktonic diatoms from North American and European lakes. Global Change Biology, 14(11), 2740-2754.

Rusiñol, M., Moriarty, E., Lin, S., Bofill-Mas, S., \& Gilpin, B. (2016). Human-, ovine-, and bovine-specific viral source tracking tools to discriminate between the major fecal sources in agricultural waters. Food and environmental virology, 8(1), 3445.

Sabo, J. L., Sponseller, R., Dixon, M., Gade, K., Harms, T., Heffernan, J., . . Watts, J. (2005). Riparian zones increase regional species richness by harboring different, not more, species. Ecology, 86(1), 56-62.

Salmanzadeh, M. (2017). Source-tracking cadmium in New Zealand agricultural soils: a stable isotope approach.

Salmaso, N. (2010). Long-term phytoplankton community changes in a deep subalpine lake: responses to nutrient availability and climatic fluctuations. Freshwater biology, 55(4), 825-846.

Salmon, J. (1975). The influence of man on the biota. In Biogeography and ecology in New Zealand (pp. 643-661): Springer.

Sander, S. G., Anderson, B., Reid, M. R., Kim, J. P., \& Hunter, K. A. (2013). Trace metal chemistry in the pristine freshwater Lake Hauroko, Fiordland, New Zealand. Microchemical Journal, 111, 74-81. doi:https://doi.org/10.1016/j.microc.2012.12.012

Sanger, J. E. (1988). Fossil pigments in paleoecology and paleolimnology. Palaeogeography, Palaeoclimatology, Palaeoecology, 62(1-4), 343-359.

Sayer, C., Roberts, N., Sadler, J., David, C., \& Wade, P. (1999). Biodiversity changes in a shallow lake ecosystem: a multi-proxy palaeolimnological analysis. Journal of Biogeography, 26(1), 97-114. 
Scarsbrook, M. R., \& Melland, A. R. (2015). Dairying and water-quality issues in Australia and New Zealand. Animal Production Science, 55(7), 856-868. doi:https://doi.org/10.1071/AN14878

Scheffer, M., Carpenter, S. R., Lenton, T. M., Bascompte, J., Brock, W., Dakos, V., . . . Van Nes, E. H. (2012). Anticipating critical transitions. Science, 338(6105), 344-348.

Schindler, D. W. (2006). Recent advances in the understanding and management of eutrophication. Limnology and oceanography, 51(1 part2), 356-363.

Schmitt, T., Dosskey, M., \& Hoagland, K. (1999). Filter strip performance and processes for different vegetation, widths, and contaminants. Journal of Environmental Quality, 28(5), 1479-1489.

Schneider, C. A., Rasband, W. S., \& Eliceiri, K. W. (2012). NIH Image to ImageJ: 25 years of image analysis. Nature methods, 9(7), 671-675.

Schneider, D., Arp, G., Reimer, A., Reitner, J., \& Daniel, R. (2013). Phylogenetic analysis of a microbialite-forming microbial mat from a hypersaline lake of the Kiritimati Atoll, Central Pacific. PLoS One, 8(6).

Schoumans, O. F., Chardon, W. J., Bechmann, M. E., Gascuel-Odoux, C., Hofman, G., Kronvang, B., . . . Dorioz, J. M. (2014). Mitigation options to reduce phosphorus losses from the agricultural sector and improve surface water quality: A review. Science of The Total Environment, 468-469, 1255-1266. doi:https://doi.org/10.1016/j.scitotenv.2013.08.061

Schwarz, J. I., Eckert, W., \& Conrad, R. (2008). Response of the methanogenic microbial community of a profundal lake sediment (Lake Kinneret, Israel) to algal deposition. Limnology and oceanography, 53(1), 113-121.

Shaw, G. R., Sukenik, A., Livne, A., Chiswell, R. K., Smith, M. J., Seawright, A. A., . . . Moore, M. R. (1999). Blooms of the cylindrospermopsin containing cyanobacterium, Aphanizomenon ovalisporum (Forti), in newly constructed lakes, Queensland, Australia. Environmental Toxicology, 14(1), 167-177. doi:10.1002/(sici)1522-7278(199902)14:1<167::Aid-tox22>3.0.Co;2-o

Shumate, B. C., Schelske, C. L., Crisman, T. L., \& Kenney, W. F. (2002). Response of the cladoceran community to trophic state change in Lake Apopka, Florida. Journal of Paleolimnology, 27(1), 71-77.

Sindayigaya, E., Van Cauwenbergh, R., Robberecht, H., \& Deelstra, H. (1994). Copper, zinc, manganese, iron, lead, cadmium, mercury and arsenic in fish from Lake Tanganyika, Burundi. Science of The Total Environment, 144(1-3), 103-115.

Smith, D. P., Thrash, J. C., Nicora, C. D., Lipton, M. S., Burnum-Johnson, K. E., Carini, P., . . Giovannoni, S. J. (2013). Proteomic and transcriptomic analyses of "Candidatus Pelagibacter ubique" describe the first PII-independent response to nitrogen limitation in a free-living Alphaproteobacterium. MBio, 4(6), e00133-00112.

Smith, V. H., \& Schindler, D. W. (2009). Eutrophication science: where do we go from here? Trends in ecology \& evolution, 24(4), 201-207.

Smith, V. H., Tilman, G. D., \& Nekola, J. C. (1999). Eutrophication: impacts of excess nutrient inputs on freshwater, marine, and terrestrial ecosystems. Environmental pollution, 100(1-3), 179-196.

Smith, V. H., Wood, S. A., McBride, C. G., Atalah, J., Hamilton, D. P., \& Abell, J. (2016). Phosphorus and nitrogen loading restraints are essential for successful eutrophication control of Lake Rotorua, New Zealand. Inland Waters, 6(2), 273283.

Smol, J. P. (1985). The ratio of diatom frustules to chrysophycean statospores: a useful paleolimnological index. Hydrobiologia, 123(3), 199-208. 
Smol, J. P. (1992). Paleolimnology: an important tool for effective ecosystem management. Journal of Aquatic Ecosystem Health, 1(1), 49-58. doi:10.1007/BF00044408

Song, M. H., Zong, N., Jiang, J., Shi, P. L., Zhang, X. Z., Gao, J. Q., . . Loreau, M. (2019). Nutrient-induced shifts of dominant species reduce ecosystem stability via increases in species synchrony and population variability. Sci Total Environ, 692, 441-449. doi:10.1016/j.scitotenv.2019.07.266

Stevens, G., McGlone, M., \& McCulloch, B. (2013). Prehistoric new zealand: Royal New Zealand Foundation of the Blind.

Stewart, G. H., \& Rose, A. B. (1990). The significance of life history strategies in the developmental history of mixed beech (Nothofagus) forests, New Zealand. Vegetatio, 87(2), 101-114.

Stoate, C., Boatman, N., Borralho, R. J., Carvalho, C. R., Snoo, G. R., \& Eden, P. (2002). Ecological impacts of arable intensification in Europe (Vol. 63).

Strain, M. C., Lada, S. M., Luong, T., Rought, S. E., Gianella, S., Terry, V. H., . . . Richman, D. D. (2013). Highly precise measurement of HIV DNA by droplet digital PCR. PLoS One, 8(4).

Striewski, B., Mayr, C., Flenley, J., Naumann, R., Turner, G., \& Lücke, A. (2009). Multi-proxy evidence of late Holocene human-induced environmental changes at Lake Pupuke, Auckland (New Zealand). Quaternary International, 202(1-2), 69-93.

Studio, R. (2019). R-Studio Package. Retrieved from https://support.rstudio.com/hc/enus

Sutton, D. G. (1987). A paradigmatic shift in Polynesian prehistory: implications for New Zealand. New Zealand Journal of Archaeology, 9(135), 55.

Sutton, D. G., Flenley, J. R., Li, X., Todd, A., Butler, K., Summers, R., \& Chester, P. I. (2008). The timing of the human discovery and colonization of New Zealand. Quaternary International, 184(1), 109-121.

Svensonn, \& Leonardson. (1996). Effects of bioturbation by tube-dwelling chironomid larvae on oxygen uptake and denitrification in eutrophic lake sediments. Freshwater biology, 35(2), 289-300.

Sze, M. A., Abbasi, M., Hogg, J. C., \& Sin, D. D. (2014). A comparison between droplet digital and quantitative PCR in the analysis of bacterial 16S load in lung tissue samples from control and COPD GOLD 2. PLoS One, 9(10).

Taylor, M. (1997). Accumulation of cadmium derived from fertilisers in New Zealand soils. Science of The Total Environment, 208(1-2), 123-126.

Taylor, M., Caldwell, J., \& Sneath, G. (2017). Current state and trend of cadmium levels in soil, freshwater and sediments across the Waikato region. Science and Policy: Nutrient Management Challenges for the Next Generation; Fertilizer and Lime Research Centre, Massey University: Palmerston North, New Zealand, 1-11.

Team, R. C. (2017). R: A Language and Environment for Statistical Computing. Retrieved from https://www.R-project.org/

Technologies, L. (2019). ThermoFisher Scientific. Retrieved from https://www.thermofisher.com/nz/en/home/brands/life-technologies.html

Thackeray, S. J., Noges, P., Dunbar, M. J., Dudley, B. J., Skjelbred, B., Morabito, G., . . . Catalan, J. (2013). Quantifying uncertainties in biologically-based water quality assessment: a pan-European analysis of lake phytoplankton community metrics. Ecological Indicators, 29, 34-47.

Thenya, T., Wassmann, R., Verchot, L., \& Mungai, D. (2006). Degradation of the riparian wetlands in the Lake Victoria basin-Yala swamp case study. 
ThermoFisher. (2019). UltraPure ${ }^{\mathrm{TM}}$ DNase/RNase-Free Distilled Water. In Invitrogen (Ed.).

Thirunavukkarasu, O., Viraraghavan, T., \& Selvapathy, P. (2000). A comparative account of phosphorus release from sediments of a lake and a reservoir: laboratory experiments. Fresenius Environmental Bulletin, 9(7/8), 461-467.

Thomsen, P. F., \& Willerslev, E. (2015). Environmental DNA-An emerging tool in conservation for monitoring past and present biodiversity. Biological Conservation, 183, 4-18.

Thornton, S., \& McManus, J. (1994). Application of organic carbon and nitrogen stable isotope and $\mathrm{C} / \mathrm{N}$ ratios as source indicators of organic matter provenance in estuarine systems: evidence from the Tay Estuary, Scotland. Estuarine, Coastal and Shelf Science, 38(3), 219-233.

Trodahl, M., Rees, A., Newnham, R., \& Vandergoes, M. (2016a). Late Holocene geomorphic history of Lake Wairarapa, North Island, New Zealand. New Zealand Journal of Geology and Geophysics, 59(2), 330-340.

Trodahl, M. I., Rees, A. B. H., Newnham, R. M., \& Vandergoes, M. J. (2016b). Late Holocene geomorphic history of Lake Wairarapa, North Island, New Zealand. New Zealand Journal of Geology and Geophysics, 59(2), 330-340. doi:10.1080/00288306.2015.1133663

Tse, T. J., Doig, L. E., Tang, S., Zhang, X., Sun, W., Wiseman, S. B., . . Hecker, M. (2018). Combining high-throughput sequencing of seda DNA and traditional paleolimnological techniques to infer historical trends in cyanobacterial communities. Environmental science \& technology, 52(12), 6842-6853.

Turner, R., Kelly, A., \& Roberts, N. (2004). A critical assessment and experimental comparison of microscopic charcoal extraction methods. Paper presented at the Proceedings of the Third International Meeting of Anthracology.

Ulén, B., \& Mattsson, L. (2003). Transport of phosphorus forms and of nitrate through a clay soil under grass and cereal production. Nutrient Cycling in Agroecosystems, 65(2), 129-140. doi:10.1023/A:1022133031584

UWITECH. (2019). Uwitech Gravity Corer. Retrieved from http://www.uwitec.at/html/corer.html

Van Dommelen, A., \& Vanderleyden, J. (2007). Associative nitrogen fixation. In Biology of the nitrogen cycle (pp. 179-192): Elsevier.

Vandergoes, M. J., Howarth, J. D., Dunbar, G. B., Turnbull, J. C., Roop, H. A., Levy, R. H., . . Bronk Ramsey, C. (2018). Integrating chronological uncertainties for annually laminated lake sediments using layer counting, independent chronologies and Bayesian age modelling (Lake Ohau, South Island, New Zealand). Quaternary Science Reviews, 188, 104-120. doi:https://doi.org/10.1016/j.quascirev.2018.03.015

Vant, B., \& Huser, B. (2000). Effects of intensifying catchment land-use on the water quality of Lake Taupo. Paper presented at the Proceedings of the New Zealand Society of Animal Production.

Verburg, P., Hamill, K., Unwin, M., \& Abell, J. (2010). Lake Water Quality in New Zealand 2010: Status and Trends.

Vincent, W., Gibbs, M., \& Dryden, S. (1984). Accelerated eutrophication in a New Zealand lake: Lake Rotoiti, central North Island. New Zealand Journal of Marine and Freshwater Research, 18(4), 431-440.

Vogel, J. R., Stoeckel, D. M., Lamendella, R., Zelt, R. B., Santo Domingo, J. W., Walker, S. R., \& Oerther, D. B. (2007). Identifying Fecal Sources in a Selected Catchment Reach Using Multiple Source-Tracking Tools. Journal of Environmental Quality, 36, 718-729. doi:10.2134/jeq2006.0246 
Von Gunten, H., \& Moser, R. (1993). How reliable is the $210 \mathrm{~Pb}$ dating method? Old and new results from Switzerland. Journal of Paleolimnology, 9(2), 161-178.

Walter, R., Buckley, H., Jacomb, C., \& Matisoo-Smith, E. (2017). Mass Migration and the Polynesian Settlement of New Zealand. Journal of World Prehistory, 30(4), 351-376. doi:10.1007/s10963-017-9110-y

Ward, R. C., Loftis, J. C., \& McBride, G. B. (1986). The "data-rich but informationpoor" syndrome in water quality monitoring. Environmental Management, 10(3), 291-297. doi:10.1007/bf01867251

Wardle, J. (1967). Vegetation of the Aorangi Range, southern Wairarapa. New Zealand journal of botany, 5(1), 22-48.

Wardle, P. (1985). Environmental influences on the vegetation of New Zealand. New Zealand journal of botany, 23(4), 773-788.

Wardle, P. (1991). Vegetation of New Zealand: Cambridge University Press.

Waters, A. S. (2016). Phosphorus dynamics in a shallow coastal lake system, Canterbury, New Zealand.

Waters, S. K., D; Vandergoes, M; Rees, A; Li, X; Cochran, L; Homes, A. (2018). ake Wairarapa - understanding the ecological past and present for future management. Retrieved from Cawthron:

Weaver, D., \& Summers, R. (2014). Fit-for-purpose phosphorus management: do riparian buffers qualify in catchments with sandy soils? Environmental Monitoring and Assessment, 186(5), 2867-2884. doi:10.1007/s10661-013-35864

Wendelken, W. (1976). Forests. New Zealand Atlas. Government Printer, 106-107.

Wetzel, R. G., \& ., A. P. (2001). Limnology: Lake and River Ecosystems: Elsevier Science.

WHO, W. H. O. (1995). Environmental health criteria 165. International Programme on Chemical Safety. Geneva: World Health Organization.

Williamson, R. B., Smith, R. K., \& Quinn, J. M. (1992). Effects of riparian grazing and channelisation on streams in Southland, New Zealand. 1. Channel form and stability. New Zealand Journal of Marine and Freshwater Research, 26(2), 241258.

Wilmshurst, J. M., Higham, T. F., Allen, H., Johns, D., \& Phillips, C. (2004). Early Maori settlement impacts in northern coastal Taranaki, New Zealand. New Zealand journal of ecology, 167-179.

Wilmshurst, J. M., Hunt, T. L., Lipo, C. P., \& Anderson, A. J. (2011). High-precision radiocarbon dating shows recent and rapid initial human colonization of East Polynesia. Proceedings of the National Academy of Sciences, 108(5), 18151820.

Winder, G. M. (2009). Grassland revolutions in New Zealand: Disaggregating a national story. New Zealand Geographer, 65(3), 187-200.

Wolfe, B., Berger, B., Filiberto, D., Pimentel, D., Poon, E., Abbett, E., . . . Nandagopal, S. (2004). Water Resources: Agricultural and Environmental Issues. BioScience, 54(10), 909-918. doi:10.1641/0006-3568(2004)054[0909:Wraaei]2.0.Co;2

Wondie, A. (2010). Improving management of shoreline and riparian wetland ecosystems: the case of Lake Tana catchment. Ecohydrology \& Hydrobiology, 10(2-4), 123-131.

Wood, V., \& Pawson, E. (2008). Information exchange and the making of the colonial farm: Agricultural periodicals in late nineteenth-century New Zealand. Agricultural history, 337-365.

Woodward, C. (2013). Eutrophication of a small, deep lake in southern New Zealand: the effects of twentieth-century forest clearance, changing nutrient influx, light penetration and bird behaviour. Journal of Paleolimnology, 50(3), 399-415. 
WORLD, i. (2019). iNtODEWORLD. Retrieved from http://intodeworld.com/

Worthy, T. H., De Pietri, V. L., \& Scofield, R. P. (2017). Recent advances in avian palaeobiology in New Zealand with implications for understanding New Zealand's geological, climatic and evolutionary histories. New Zealand Journal of Zoology, 44(3), 177-211. doi:10.1080/03014223.2017.1307235

Yackulic, E. (2017). Productivity and temperature variability over the past 15000 years at a small Alpine Lake in the southern San Juan Mountains, Colorado. Northern Arizona University,

Yang, X., Anderson, N. J., Dong, X., \& Shen, J. (2008). Surface sediment diatom assemblages and epilimnetic total phosphorus in large, shallow lakes of the Yangtze floodplain: their relationships and implications for assessing long-term eutrophication. Freshwater biology, 53(7), 1273-1290.

Yang, X.-e., Wu, X., Hao, H.-1., \& He, Z.-1. (2008). Mechanisms and assessment of water eutrophication. Journal of Zhejiang University. Science. B, 9(3), 197-209. doi:10.1631/jzus.B0710626

Young, J. (1992). Phylogenetic classification of nitrogen-fixing organisms. Biological nitrogen fixation, 1544, 43-86.

Zhang, W., Rong, N., Jin, X., Li, J., Ding, Y., Xiaolei, Z., \& Baoqing, S. (2015). Phosphorus speciation of sediments from lakes of different tropic status in Eastern China (Vol. 23).

Zhang, X., Liu, X., Zhang, M., Dahlgren, R. A., \& Eitzel, M. (2010). A review of vegetated buffers and a meta-analysis of their mitigation efficacy in reducing nonpoint source pollution. Journal of Environmental Quality, 39(1), 76-84.

Zhao, Y., Sayer, C. D., Birks, H. H., Hughes, M., \& Peglar, S. M. (2006). Spatial representation of aquatic vegetation by macrofossils and pollen in a small and shallow lake. Journal of Paleolimnology, 35(2), 335-350.

Zhu, Y., Wu, F., He, Z., Guo, J., Qu, X., Xie, F., . . Guo, F. (2013). Characterization of organic phosphorus in lake sediments by sequential fractionation and enzymatic hydrolysis. Environmental science \& technology, 47(14), 7679-7687.

Zolitschka, B. (1991). Absolute dating of late Quaternary lacustrine sediments by high resolution varve chronology. Hydrobiologia, 214(1), 59-61. 


\section{APPENDIX}

An online digital data file has been created at:

https://www.dropbox.com/sh/tkudy5uh8ok7qb7/AADbT9M9M4ZUIsjhUIveapzNa?dl= $\underline{0}$

\subsection{A - Lake Nganoke Master Record}

Table 2: Pb210, Bomb spike, conventional 14C and bio stratigraphic age constraints for the Lake Nganoke master record.

Calibrated radiocarbon dates (AD), minimum 95\% (CI), maximum 95\% CI and mean calibrated with SHCal13 (Hogg et al., 2013) and SH1-2 using (Hua et al., 2013) OxCal online.

\begin{tabular}{|c|c|c|c|c|c|c|c|}
\hline $\begin{array}{l}\text { Master } \\
\text { Depth } \\
\text { (cm) }\end{array}$ & $\begin{array}{l}\text { Macro } \\
\text { Type }\end{array}$ & Sample ID & $\begin{array}{l}\text { CRA } \\
\text { Ye BP }\end{array}$ & $\begin{array}{l}\text { Uncertain } \\
\text { ty }\end{array}$ & $\begin{array}{l}\text { Min } \\
95 \% \\
\text { CI }\end{array}$ & $\begin{array}{l}\text { Max } \\
95 \% \\
\text { CI }\end{array}$ & $\begin{array}{l}\text { Mea } \\
\text { n }\end{array}$ \\
\hline 1.6 & $\mathrm{~Pb}^{210}$ & $\begin{array}{l}\text { L380_NGAN } \\
\text { O_LC2U_11 } \\
\mathrm{cm}\end{array}$ & Modern & 8 & 2003 & 2020 & 2012 \\
\hline 3.7 & $\mathrm{~Pb}^{210}$ & $\begin{array}{l}\text { L380_NGAN } \\
\text { O_LC2U_13 } \\
\text { cm }\end{array}$ & Modern & 15 & 1992 & 2022 & 2007 \\
\hline 5.7 & $\mathrm{~Pb}^{210}$ & $\begin{array}{l}\text { L380_NGAN } \\
\text { O_LC2U_15 } \\
\mathrm{cm}\end{array}$ & Modern & 10 & 1991 & 2011 & 2001 \\
\hline 7.8 & $\mathrm{~Pb}^{210}$ & $\begin{array}{l}\text { L380_NGAN } \\
\text { O_LC2U_17 } \\
\mathrm{cm}\end{array}$ & Modern & 9 & 1981 & 1999 & 1990 \\
\hline 9.8 & $\mathrm{~Pb}^{210}$ & $\begin{array}{l}\text { L380_NGAN } \\
\text { O_LC2U_19 } \\
\mathrm{cm}\end{array}$ & Modern & 20 & 1960 & 2000 & 1980 \\
\hline 11.9 & $\mathrm{~Pb}^{210}$ & $\begin{array}{l}\text { L380_NGAN } \\
\text { O_LC2U_21 } \\
\mathrm{cm}\end{array}$ & Modern & 15 & 1954 & 1986 & 1970 \\
\hline 12.6 & $\begin{array}{l}\text { Seed } \\
\text { Capsul } \\
\mathrm{e} \\
\end{array}$ & $\begin{array}{l}\text { L380_NGAN } \\
\text { O_LC2U_1A } \\
\text { RC } 18.5 \mathrm{~cm} \\
\end{array}$ & Modern & NA & 1953 & 1963 & 1957 \\
\hline 13.9 & $\mathrm{~Pb}^{210}$ & $\begin{array}{l}\text { L380_NGAN } \\
\text { O_LC2U_23 } \\
\mathrm{cm}\end{array}$ & Modern & 26 & 1930 & 1984 & 1956 \\
\hline 14 & $\begin{array}{l}\text { Manuk } \\
\text { a/Kanu } \\
\text { ka }\end{array}$ & $\begin{array}{l}\text { L380_NGAN } \\
\text { O_LC3U_1B } \\
\text { RC_20.5cm }\end{array}$ & Modern & NA & 1953 & 1962 & 1955 \\
\hline 16 & $\mathrm{~Pb}^{210}$ & $\begin{array}{l}\text { L380_NGAN } \\
\text { O_LC2U_25 } \\
\text { cm }\end{array}$ & Modern & 17 & 1917 & 1951 & 1934 \\
\hline 38.5 & Pollen & Willow & 80 & 10 & 1853 & 1890 & 1871 \\
\hline 51.5 & Pollen & Pine & 85 & 20 & 1809 & 1870 & 1840 \\
\hline
\end{tabular}




\begin{tabular}{llllllll}
\hline 62.8 & Leaf & L380_NGAN & 481 & 20 & 1415 & 1446 & 1431 \\
& $\begin{array}{l}\text { Fragme } \\
\text { nts }\end{array}$ & O_LC2U 68- & & & & & \\
& & & & & & \\
\hline
\end{tabular}

\subsection{B - Full Pollen Taxonomy}

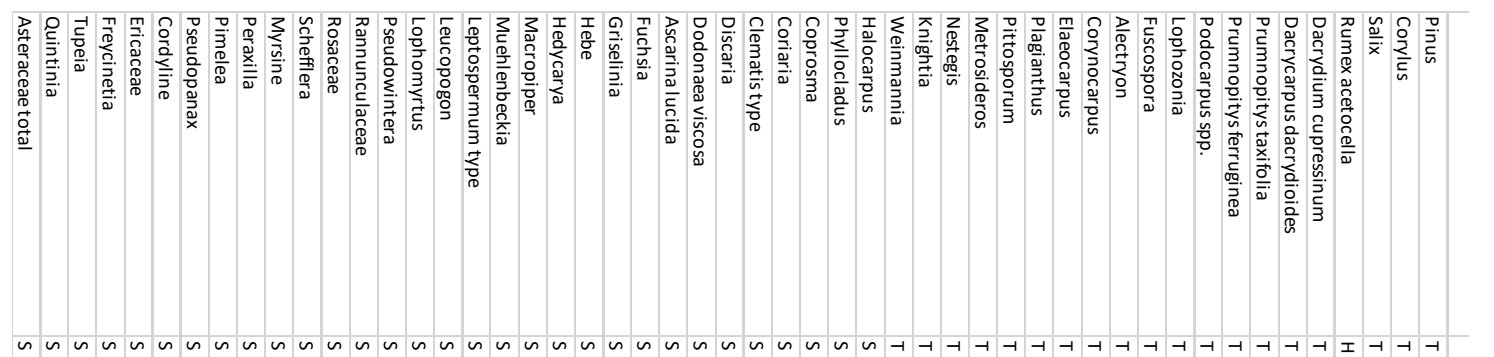

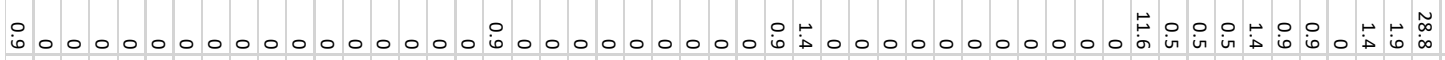

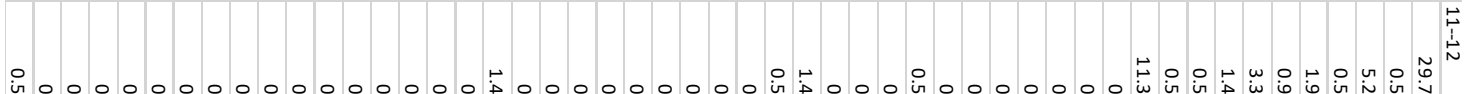
-

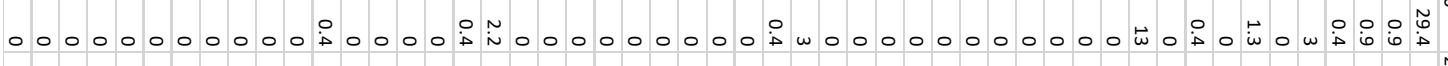

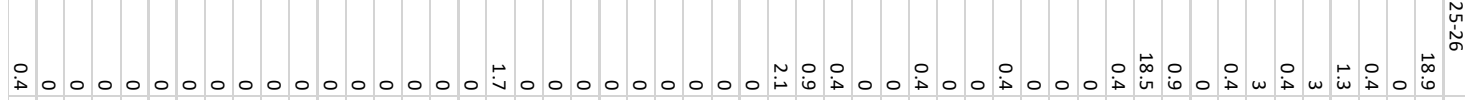

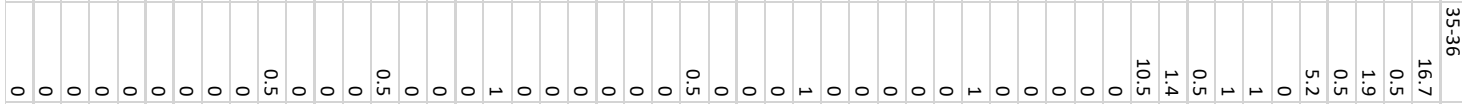

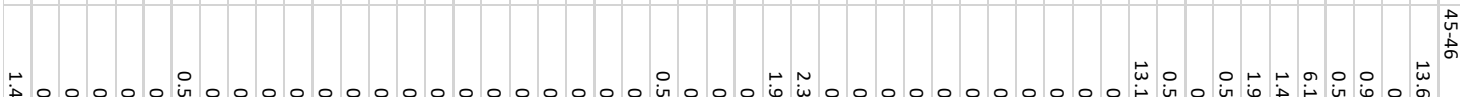

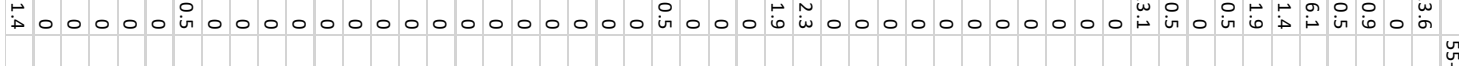

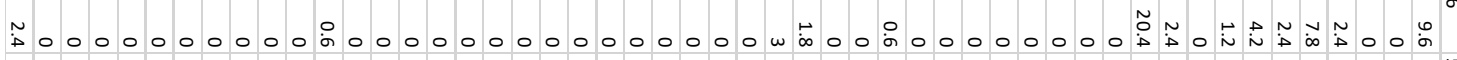
N To

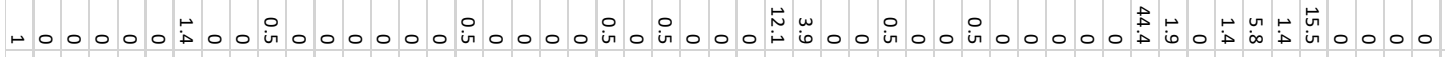

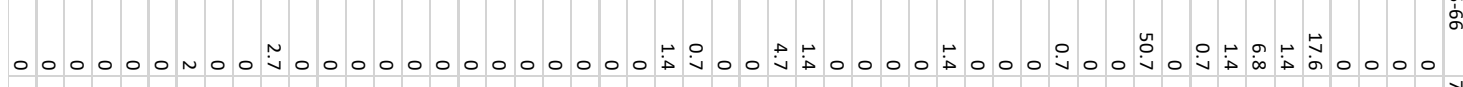
-

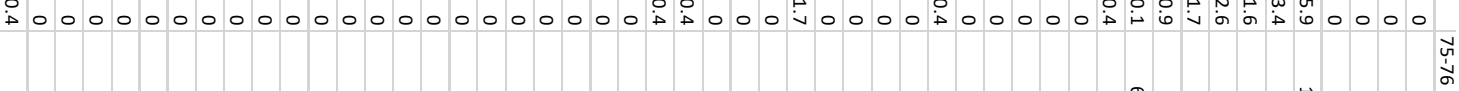

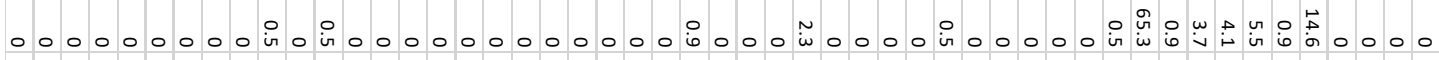

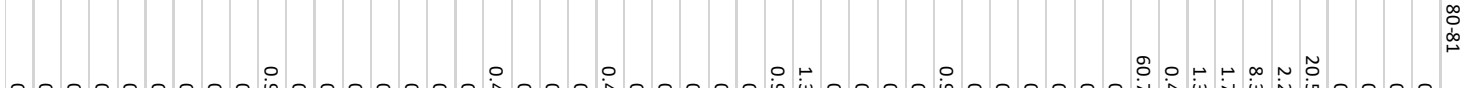

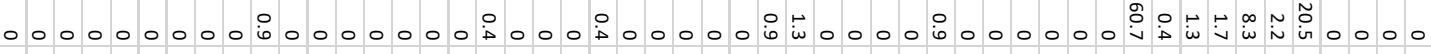

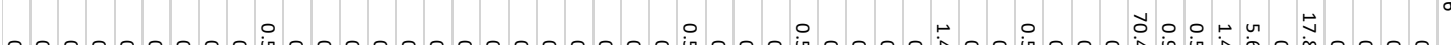

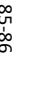

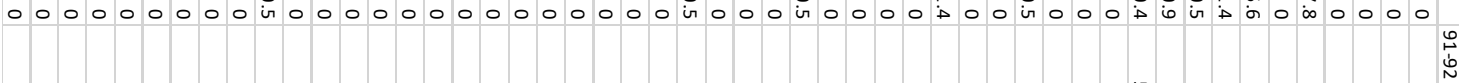
0000 in 000 in 0000000 in 0000000000 int 0000000000 in

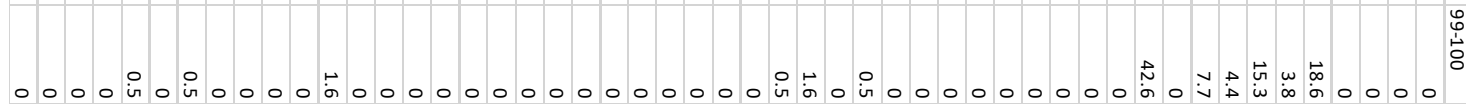




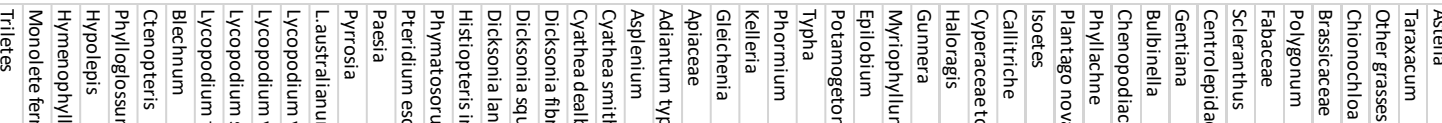

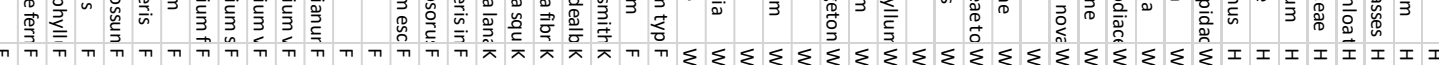

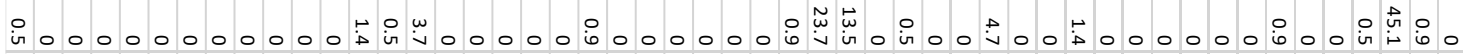

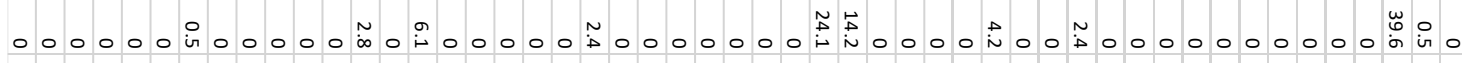

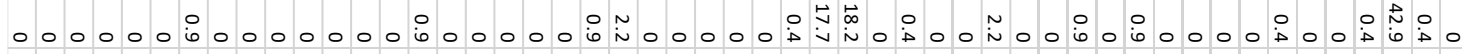

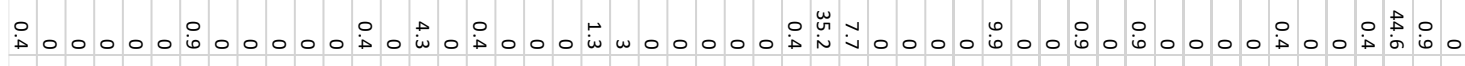

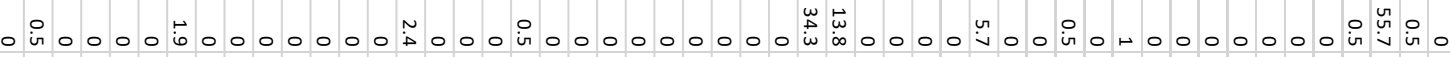

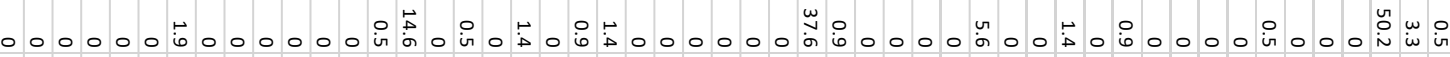

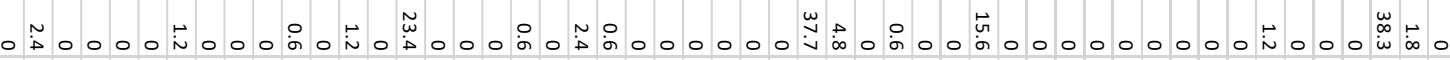

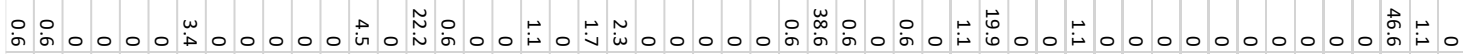

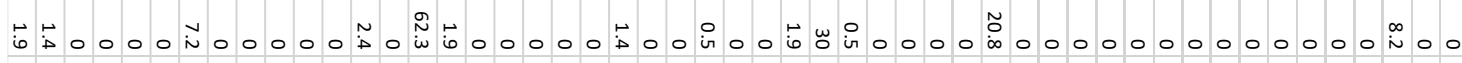

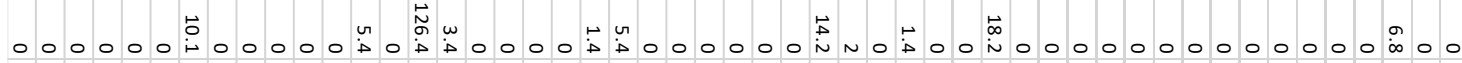

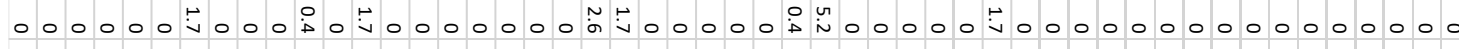
000000000000000000 in 0 in

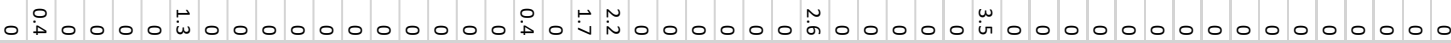

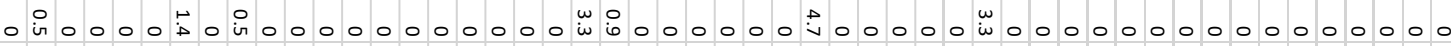

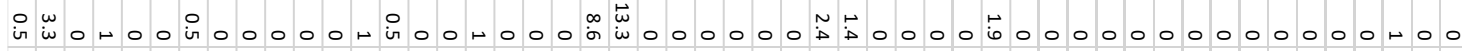

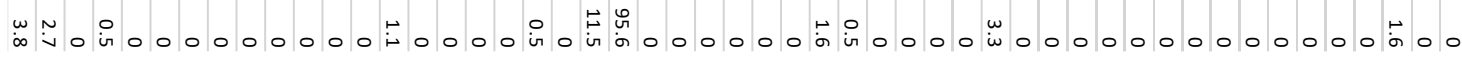




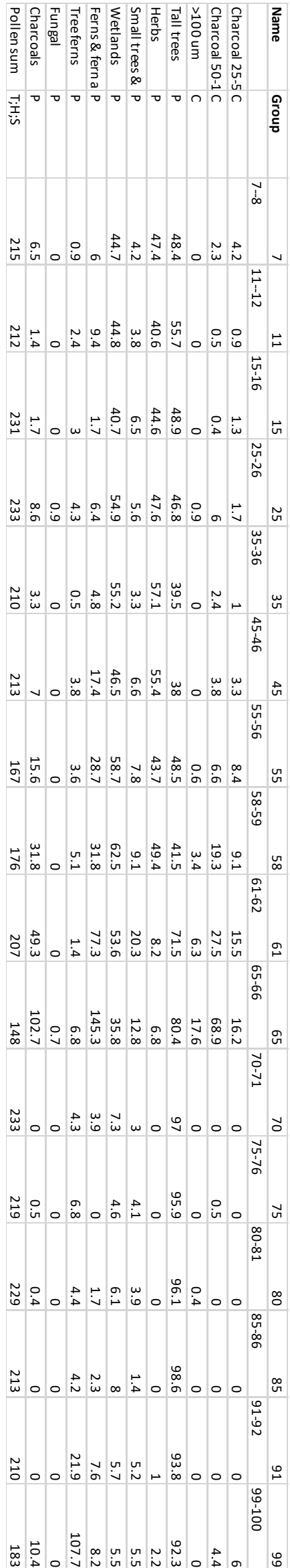

Figure 10.1 Full pollen taxonomy with depth along the top 


\subsection{C - RESULTS SECTION 6.2 AND 6.3 PLOTTED ON DEPTH}

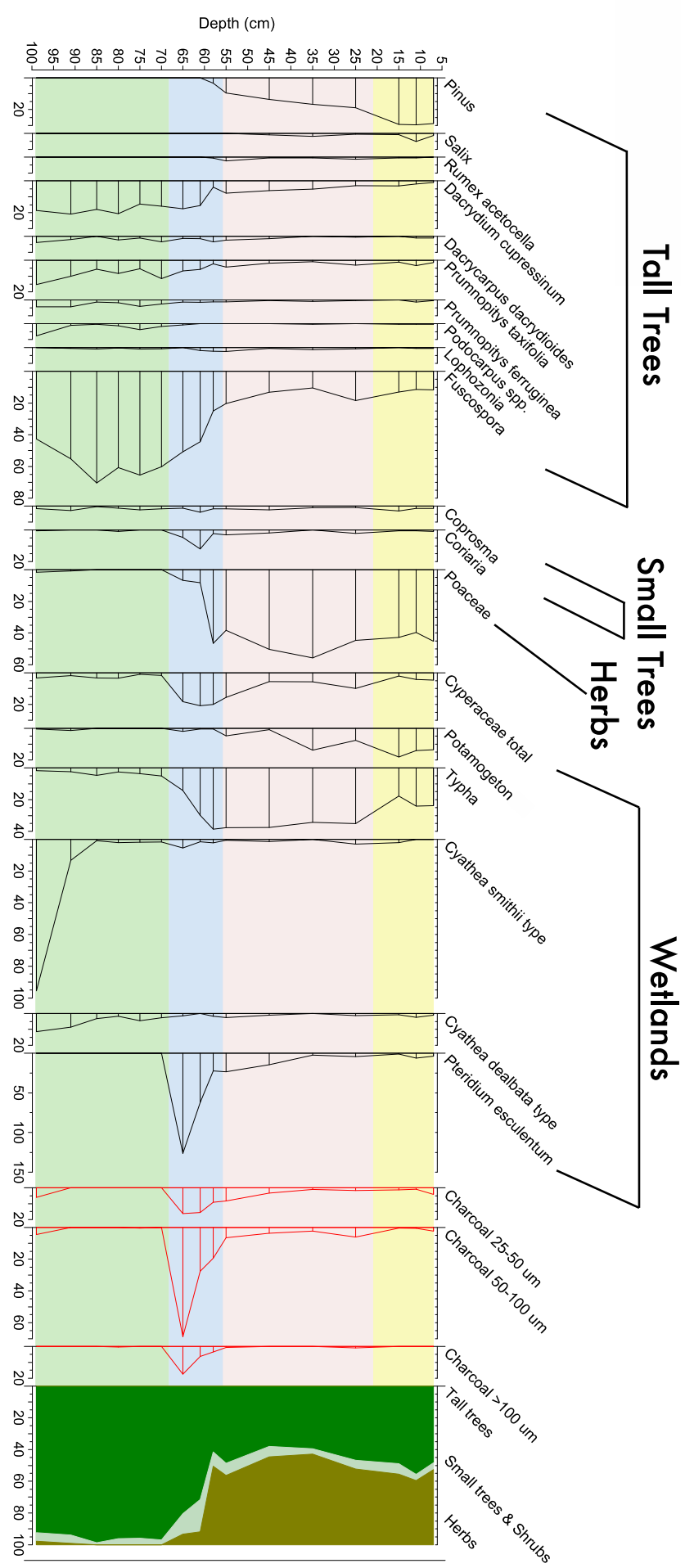

Figure 10.2 Stratigraphy of key pollen taxa plotted on depth.

The y-axis constrains depth, while the x-axis illustrates the abundance of different taxa, with the panel on the far right showing cumulative percentages based on forest and grassland vegetation type. 


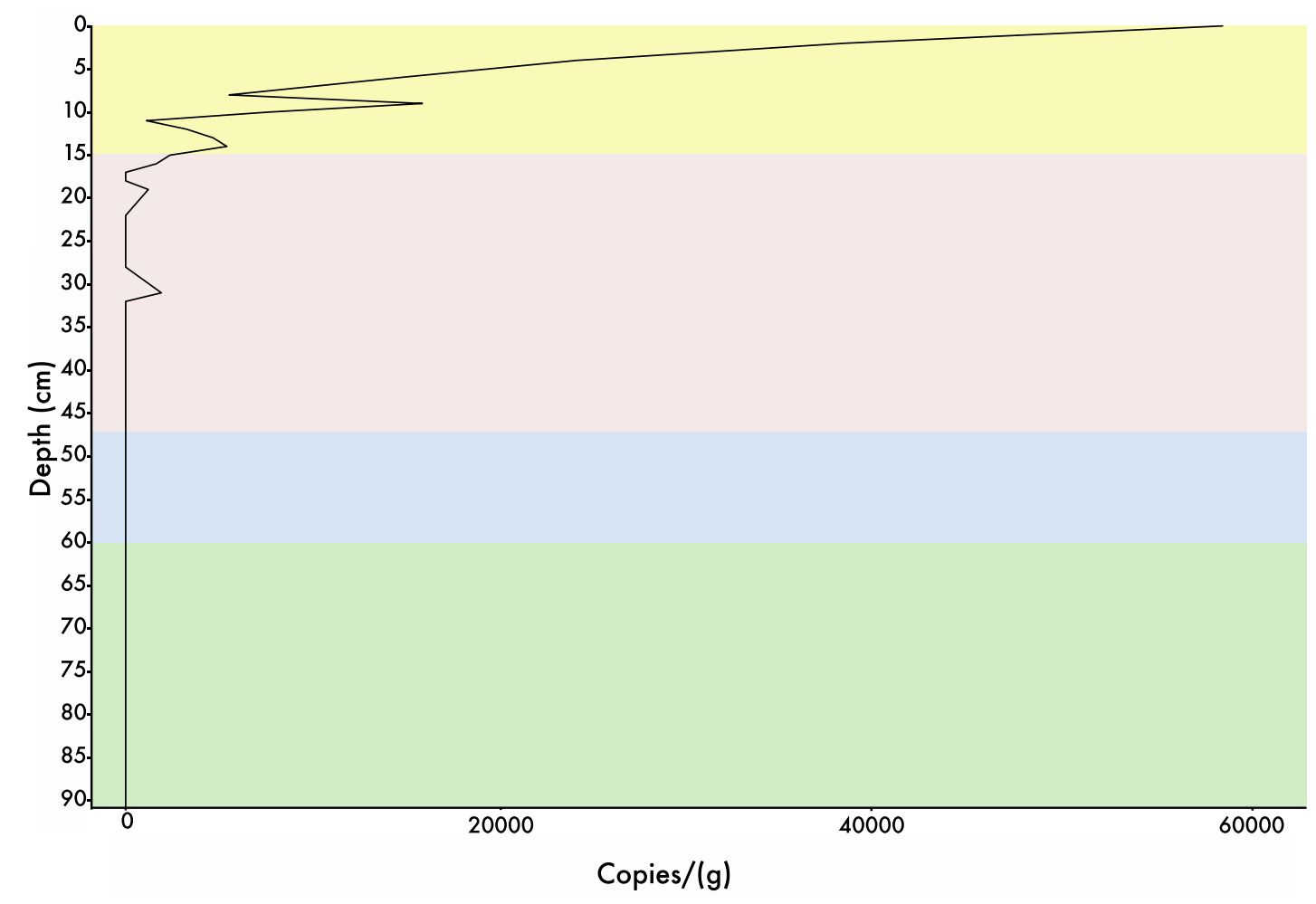

Figure 10.3 Digital droplet ruminant PCR of Lake Nganoke plotted on depth

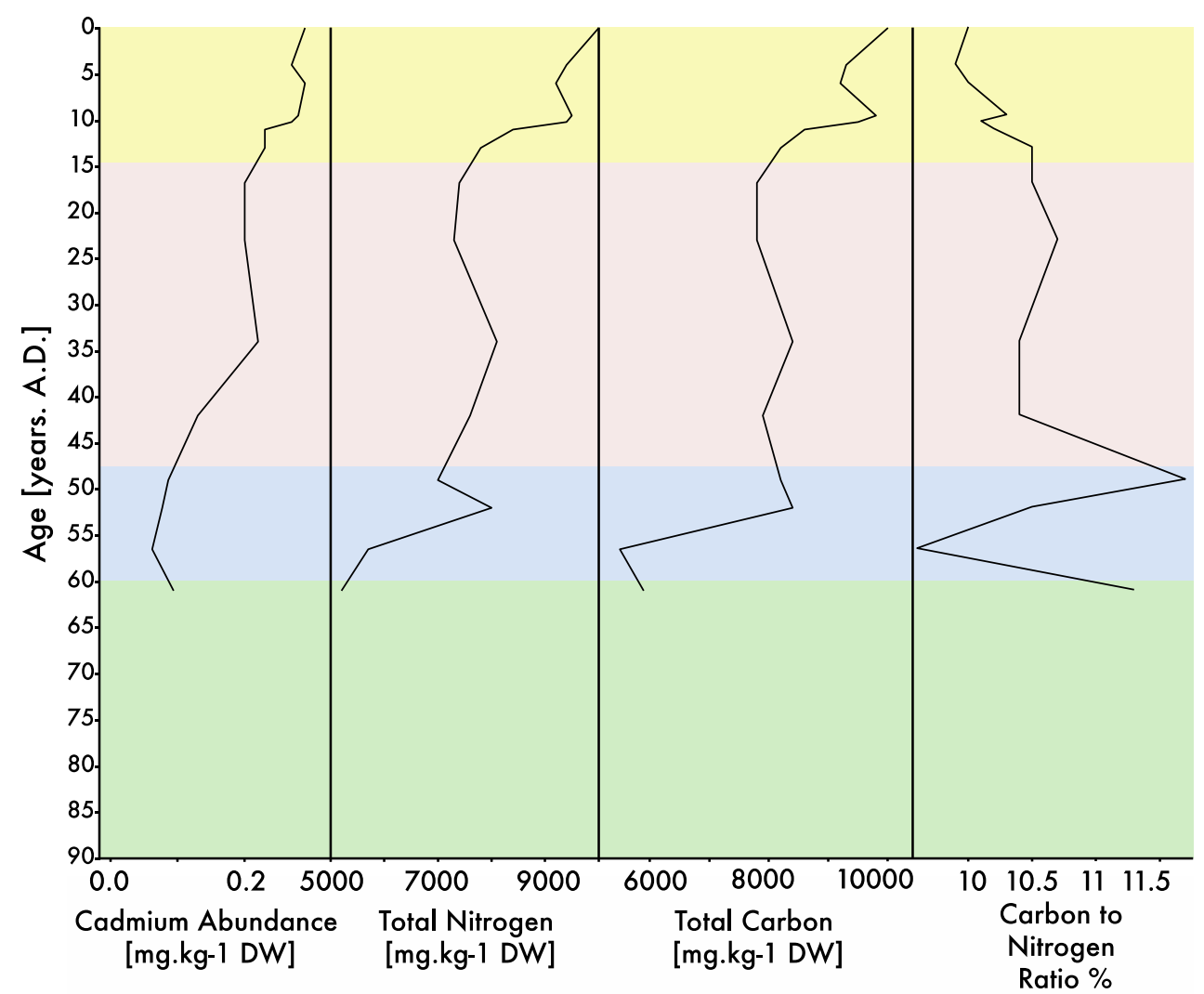

Figure 10.4 Geo-chemical analysis of cadmium, total nitrogen (TN), total carbon (TC) and carbon to nitrogen ratio $(\mathrm{C}: \mathrm{N}$ ratio) plotted on depth 

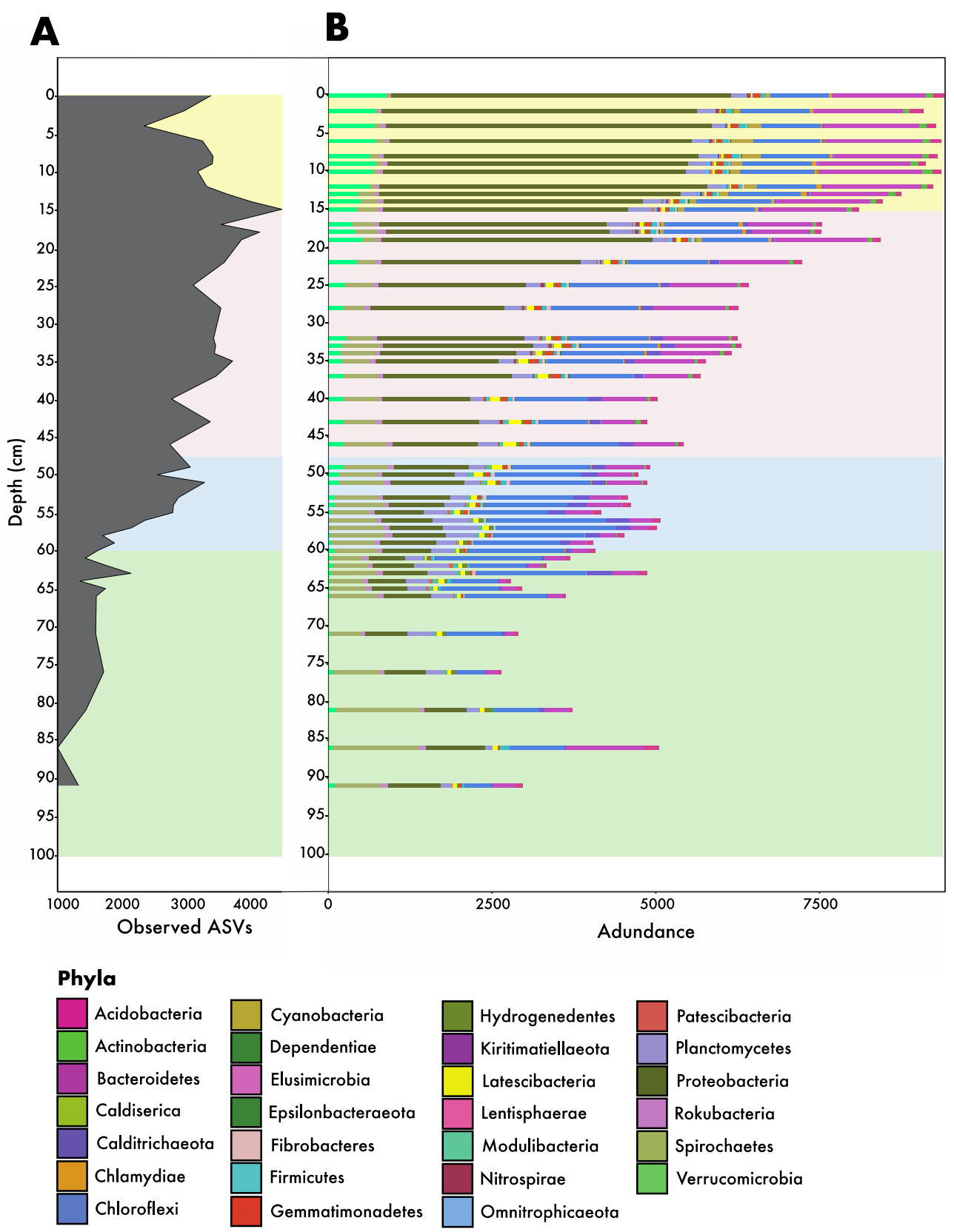

Figure 10.5 Taxonomic composition (reads per samples) (B) and richness (Observed ASV's) (A) of Lake Nganoke at Phylum level plotted on depth 


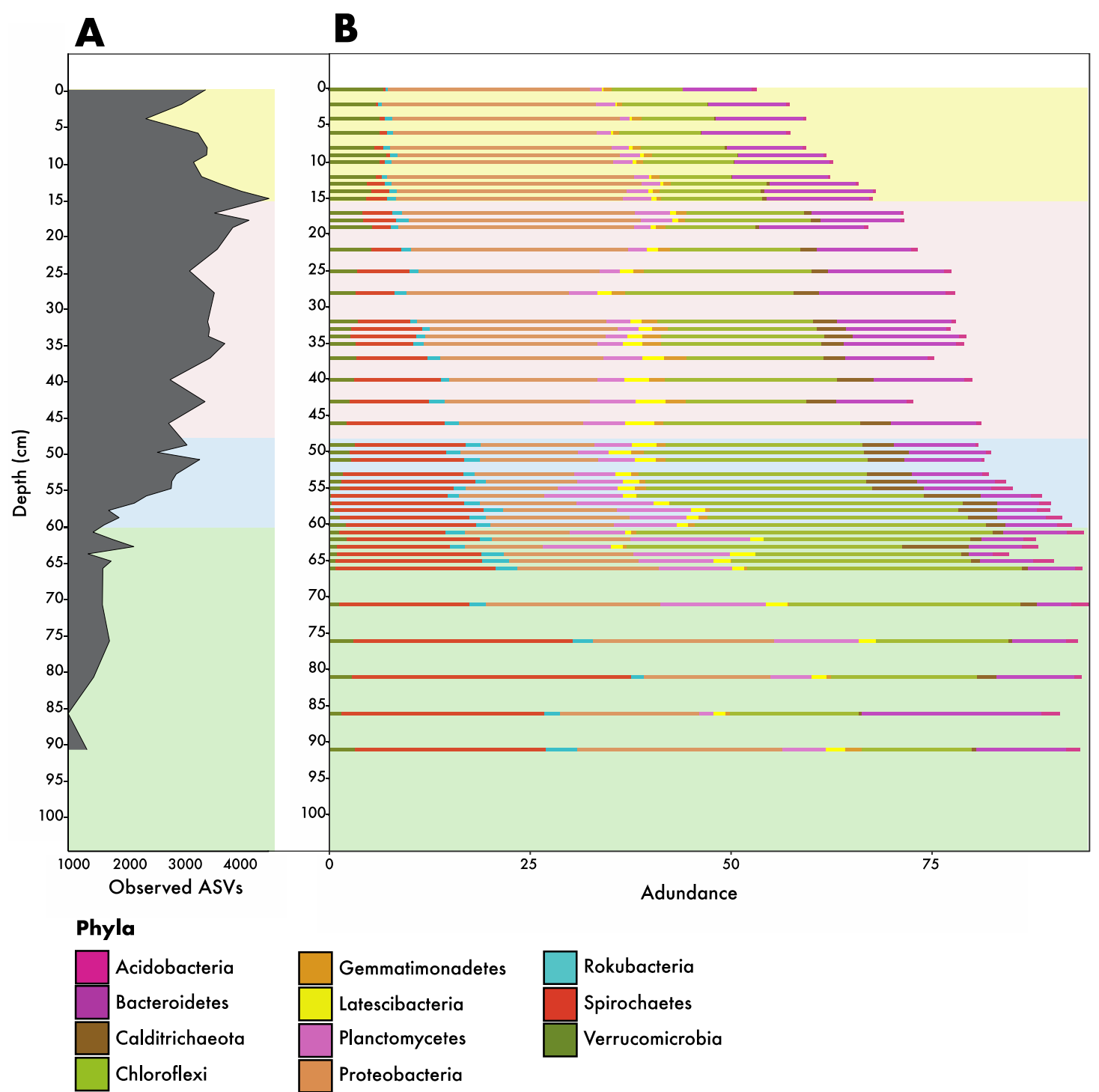

Figure 10.6 Taxonomic percentage abundance (percentage of reads per sample) $(B)$ and richness (observed ASV's) (A) of Lake Nganoke at Phylum level plotted on depth Important to note, only includes phyla that have a mean greater than one are included within this figure 


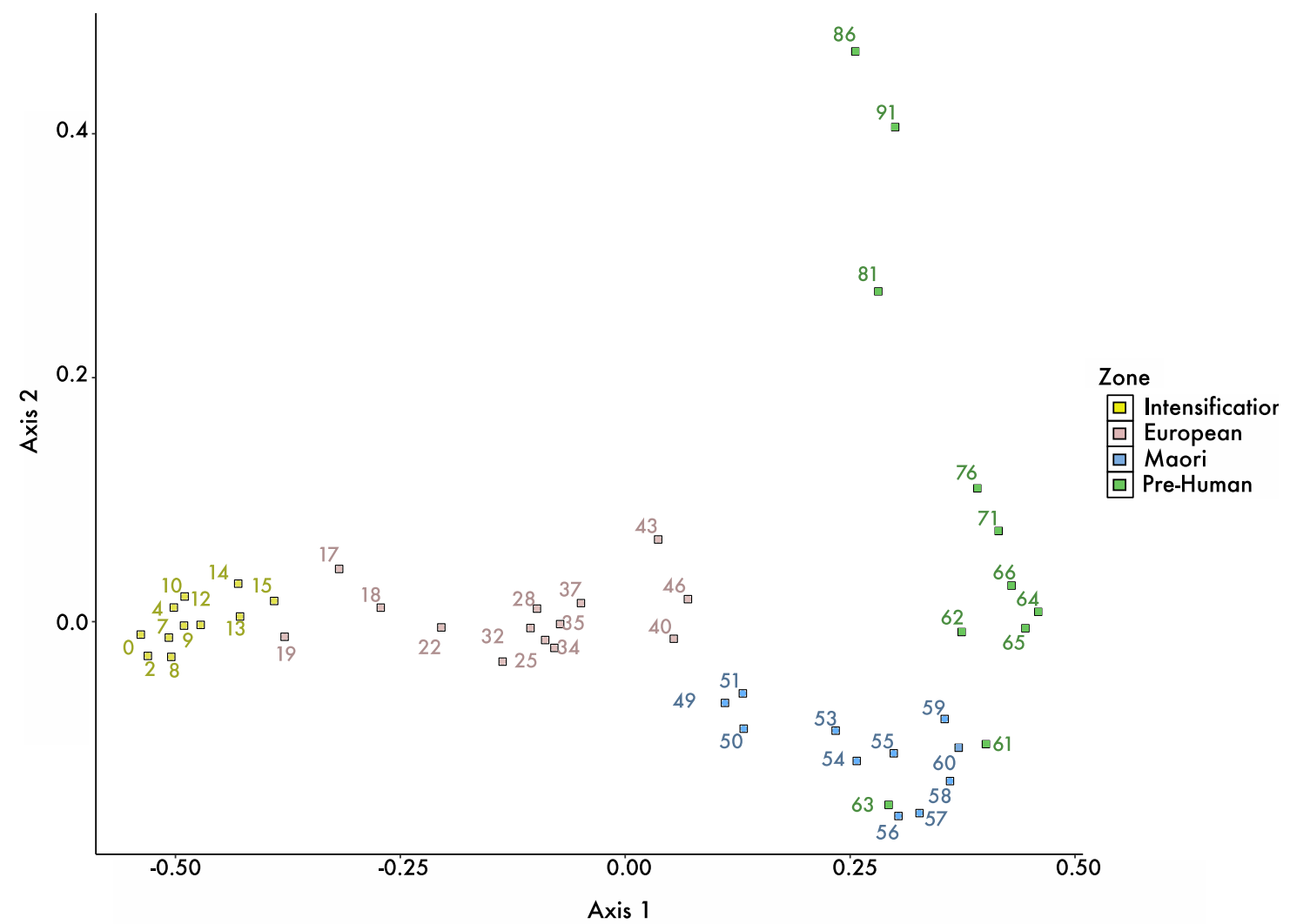

Figure 10.7 Two-dimensional non-metric multidimensional scaling plot displaying taxonomic differences between landuse zones plotted on depth

Intensification: yellow, European: pink. Māori: blue and Pre-Human: green. Data was transformed prior to ordination calculated using the Bray-Curtis dissimilarity distance 

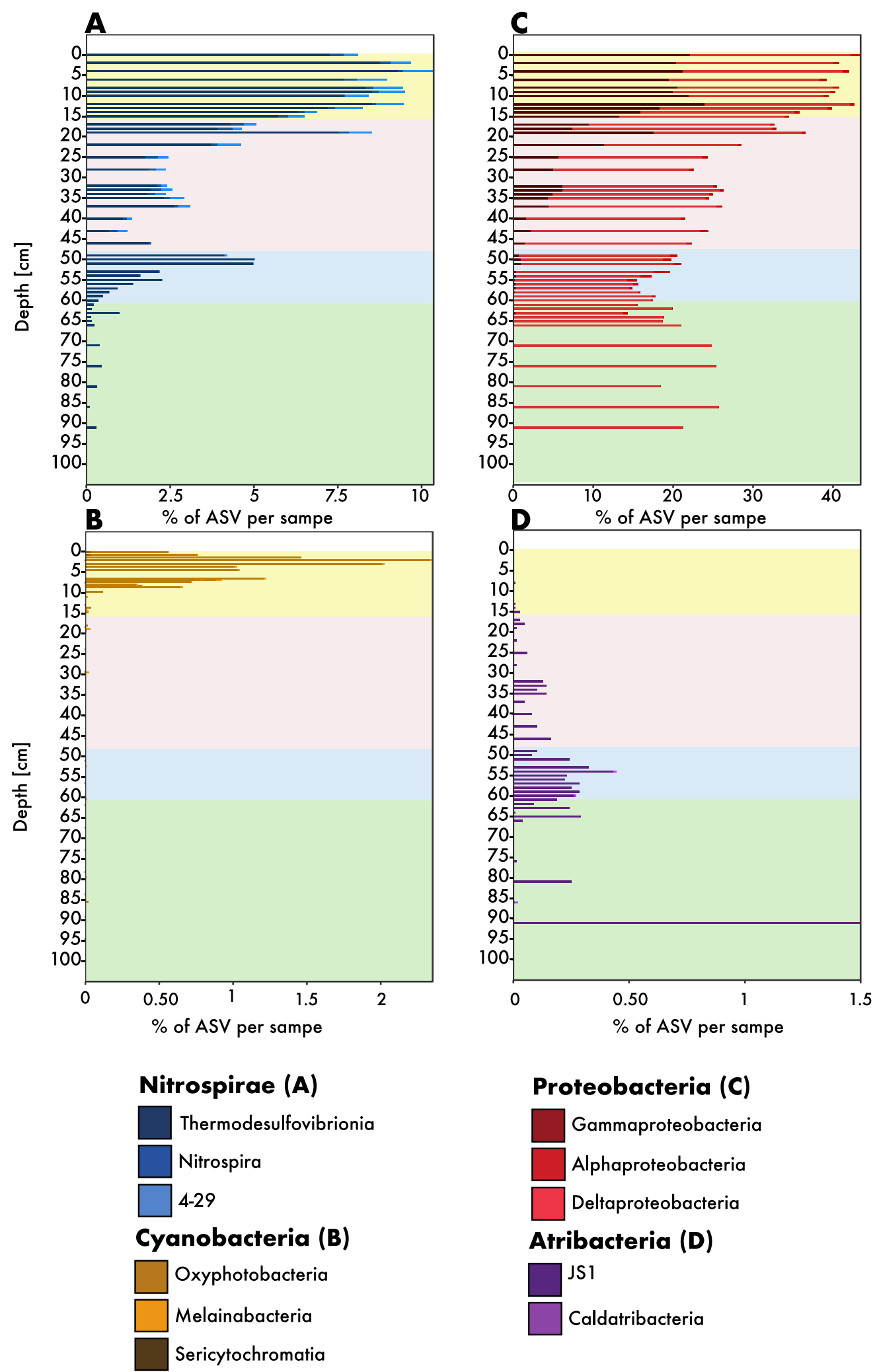

\section{Proteobacteria (C)}

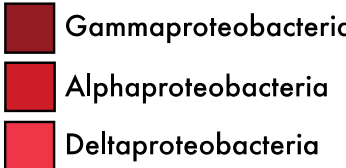

\section{Atribacteria (D)}

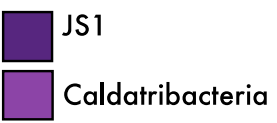

Figure 10.8 Taxa indicative of changes in lake water quality and ecosystem identified through literature plotted on depth

Identified taxa consist of Phylum Nitrospirae (classes Thermodesulfovibrionia, Nitrospira and 4-29 - Blues), Phylum (Proteobacteria and classes Gammaproteobacteria, Alphaproteobacteria and Deltaproteobacteria - Reds), Phylum (Cyanobacterian (classes Oxyphotobacteria, Melainabacteria and Sericytochromatia - Golds) and Phylum Atribacteria (classes JS1 and Caldatribacteria - Purples) 


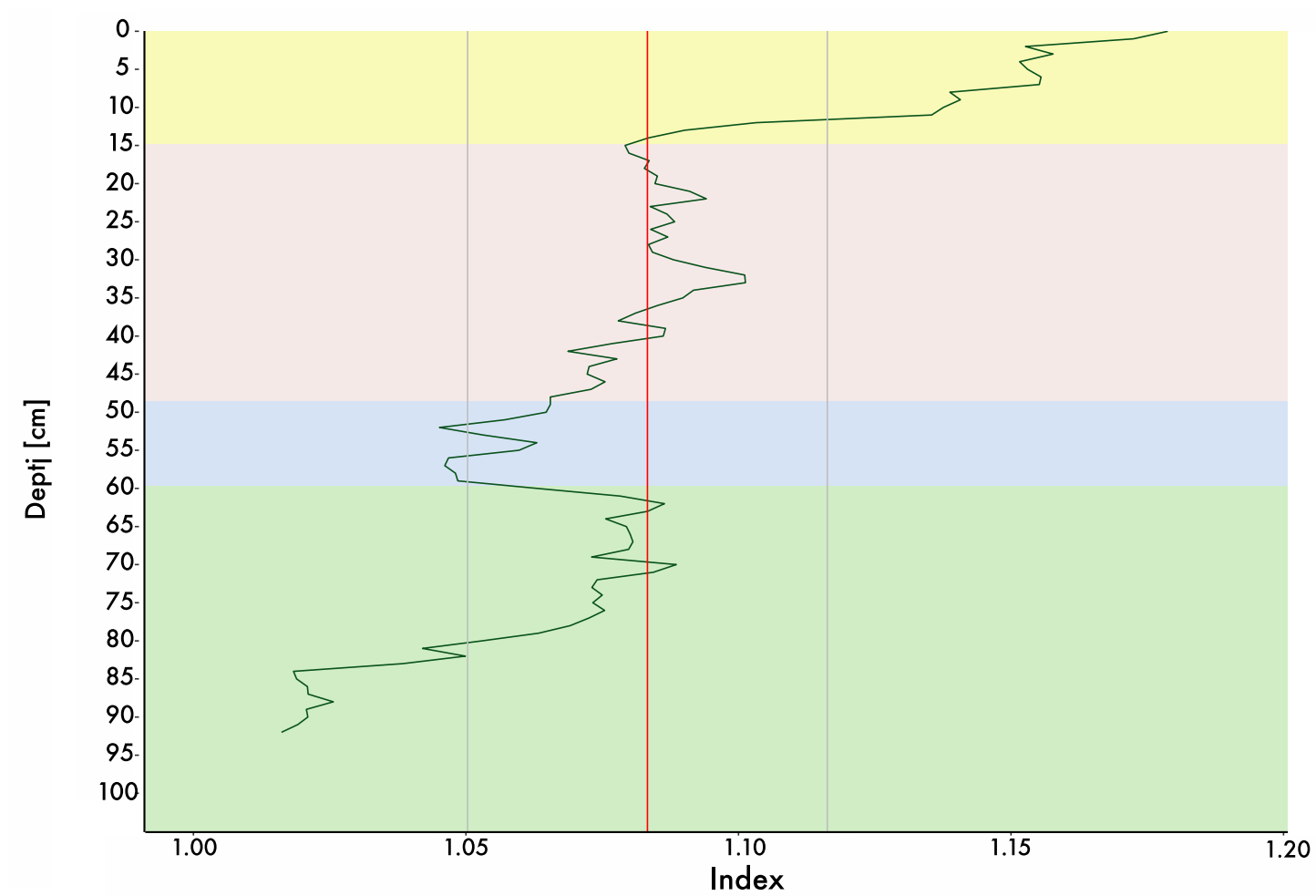

Figure 10.9 Hyperspectral ratio of the $660 / 670 \mathrm{~nm}$ band (green) in Lake Nganoke with mean value of 1.803 (red) and standard deviation of 0.033 (grey) plotted on depth

In order to calculate abundance, measurements are taken of the reflective absorption band at $\sim 680 \mathrm{~nm}$, with the data averaged at each depth $(1 \mathrm{~cm})$ to minimise noise.

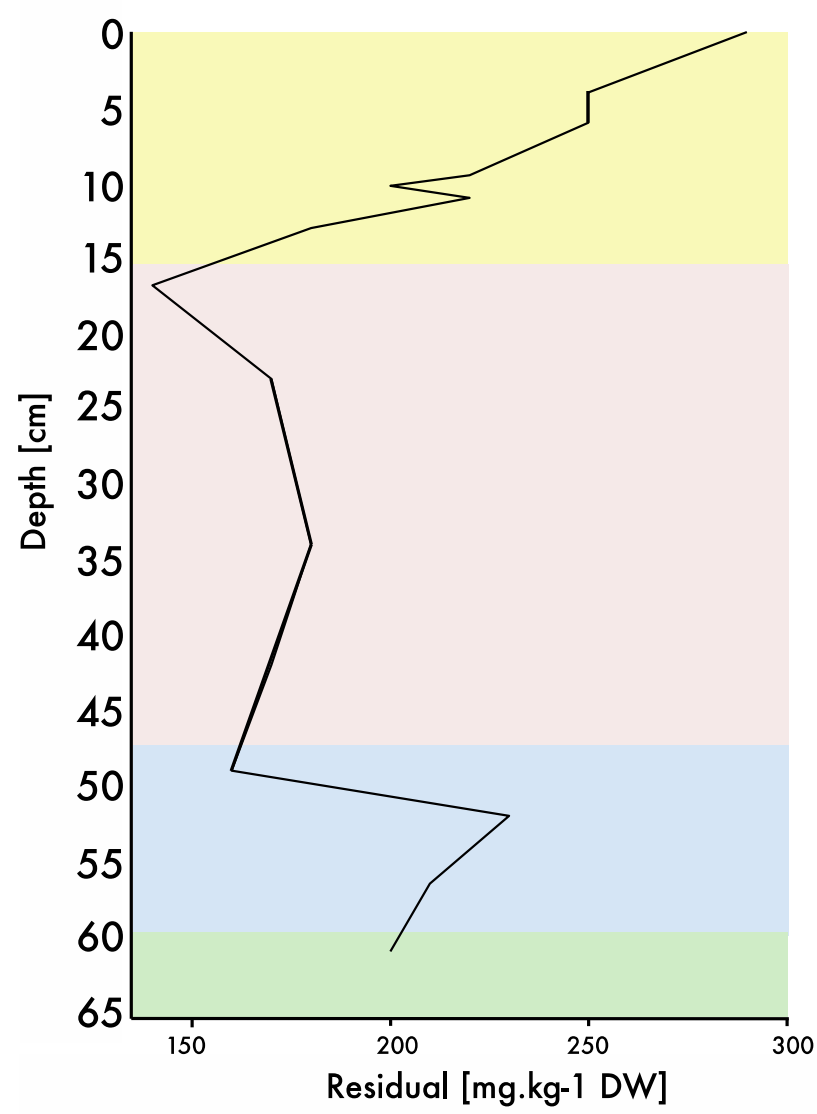

Figure 10.10 Fractions of residual phosphorous calculated by sequential extraction plotted on depth 
